\title{
SUMMARY OF THE COLUMBIA PLATEAU REGIONAL AQUIFER-SYSTEM ANALYSIS, WASHINGTON, OREGON, AND IDAHO
}

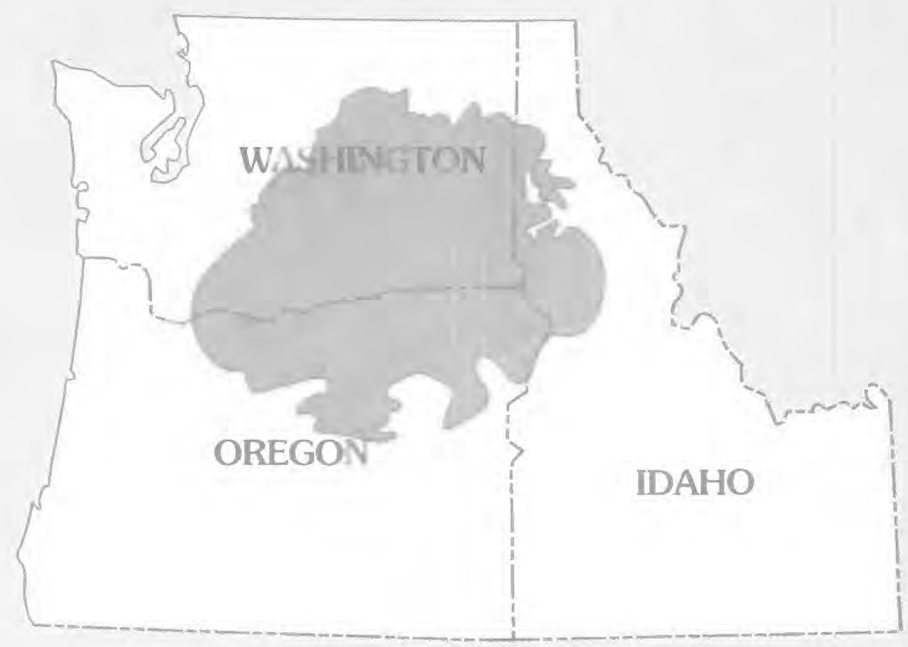




\section{Availability of Publications of the U.S. Geological Survey}

Order U.S. Geological Survey (USGS) publications from the offices listed below. Detailed ordering instructions, along with prices of the last offerings, are given in the current-year issues of the catalog "New Publications of the U.S. Geological Survey."

\section{Books, Maps, and Other Publications}

\section{By Mail}

Books, maps, and other publications are available by mail from-

USGS Information Services

Box 25286, Federal Center

Denver, CO 80225

Publications include Professional Papers, Bulletins, WaterSupply Papers, Techniques of Water-Resources Investigations, Circulars, Fact Sheets, publications of general interest, single copies of permanent USGS catalogs, and topographic and thematic maps.

\section{Over the Counter}

Books, maps, and other publications of the U.S. Geological Survey are available over the counter at the following USGS Earth Science Information Centers (ESIC's), all of which are authorized agents of the Superintendent of Documents:

- Anchorage, Alaska-Rm. 101, 4230 University Dr.

- Denver, Colorado-Bldg. 810, Federal Center

- Menlo Park, California-Rm. 3128, Bldg. 3, 345 Middlefield Rd.

- Reston, Virginia-Rm. 1C402, USGS National Center, 12201 Sunrise Valley Dr.

- Salt Lake City, Utah-2222 West, 2300 South (books and maps available for inspection only)

- Spokane, Washington-Rm. 135, U.S. Post Office Building, 904 West Riverside Ave.

- Washington, D.C.-Rm. 2650, Main Interior Bldg., 18th and C Sts., NW.

Maps only may be purchased over the counter at the following USGS office:

- Rolla, Missouri-1400 Independence Rd.

\section{Electronically}

Some USGS publications, including the catalog "New Publications of the U.S. Geological Survey" are also available electronically on the USGS's World Wide Web home page at http://www.usgs.gov

\section{Preliminary Determination of Epicenters}

Subscriptions to the periodical "Preliminary Determination of Epicenters" can be obtained only from the Superintendent of
Documents. Check or money order must be payable to the Superintendent of Documents. Order by mail from-

Superintendent of Documents

Government Printing Office

Washington, DC 20402

\section{Information Periodicals}

Many Information Periodicals products are available through the systems or formats listed below:

\section{Printed Products}

Printed copies of the Minerals Yearbook and the Mineral Commodity Summaries can be ordered from the Superintendent of Documents, Government Printing Office (address above). Printed copies of Metal Industry Indicators and Mineral Industry Surveys can be ordered from the Center for Disease Control and Prevention, National Institute for Occupational Safety and Health, Pittsburgh Research Center, P.O. Box 18070, Pittsburgh, PA 15236-0070.

\section{Mines FaxBack: Return fax service}

1. Use the touch-tone handset attached to your fax machine's telephone jack. (ISDN [digital] telephones cannot be used with fax machines.)

2. Dial (703) 648-4999.

3. Listen to the menu options and punch in the number of your selection, using the touch-tone telephone.

4. After completing your selection, press the start button on your fax machine.

\section{CD-ROM}

A disc containing chapters of the Minerals Yearbook (199395), the Mineral Commodity Summaries (1995-97), a statistical compendium (1970-90), and other publications is updated three times a year and sold by the Superintendent of Documents, Government Printing Office (address above).

\section{World Wide Web}

Minerals information is available electronically at http://minerals.er.usgs.gov/minerals/

\section{Subscription to the catalog "New Publications of the U.S. Geological Survey"}

Those wishing to be placed on a free subscription list for the catalog "New Publications of the U.S. Geological Survey" should write to-

U.S. Geological Survey

903 National Center

Reston, VA 20192 


\section{Summary of the Columbia Plateau Regional Aquifer-System Analysis, Washington, Oregon, and Idaho}

By.J.J. VACCARO

REGIONAL AQUIFER-SYSTEM ANALYSIS-COLUMBIA PLATEAU

U.S. GEOLOGICAL SURVEY PROFESSIONAL PAPER 1413-A 


\section{U.S. DEPARTMENT OF THE INTERIOR \\ BRUCE BABBITT, Secretary}

\section{U.S. GEOLOGICAL SURVEY}

Charles G. Groat, Director

Any use of trade, product, or firm names in this publication is for descriptive purposes only and does not imply endorsement by the U.S. Government.

Reston, Virginia 1999

Library of Congress Cataloging in Publication Data

Vaccaro, J.J.

Summary of the Columbia plateau regional aquifer-system analysis, Washington, Oregon, and Idaho/ by John J. Vaccaro.

p. cm.-(Regional aquifer-system analysis--Washington, Oregon, Idaho) (U.S. Geological Survey professional paper; 1413-A)

Includes bibliographical references.

Supt. of Docs. no.: I 19.16:1413-A

1. Groundwater-Columbia Plateau. 2. Water quality-Columbia Plateau. I. Title. II. Series. III. Series: U.S. Geological Survey professional paper; 1413-A QE75.P9 no. 1413-A

[GB1020]

$557.3 \mathrm{~s}-\mathrm{dc} 21$

[551.49'09795 


\section{FOREWORD}

\section{THE REGIONAL AQUIFER-SYSTEM ANALYSIS PROGRAM}

The Regional Aquifer-System Analysis (RASA) Program represents a systematic effort to study a number of the Nation's most important aquifer systems, which, in aggregate, underlie much of the country and which represent an important component of the Nation's total water supply. In general, the boundaries of these studies are identified by the hydrologic extent of each system and, accordingly, transcend the political subdivisions to which investigations have often arbitrarily been limited in the past. The broad objective for each study is to assemble geologic, hydrologic, and geochemical information; to analyze and develop an understanding of the system; and to develop predictive capabilities that will contribute to the effective management of the system. The use of computer simulation is an important element of the RASA studies to develop an understanding of the natural, undisturbed hydrologic system and the changes brought about in it by human activities, and to provide a means of predicting the regional effects of future pumping or other stresses.

The final interpretive results of the RASA Program are presented in a series of U.S. Geological Survey Professional Papers that describe the geology, hydrology, and geochemistry of each regional aquifer system. Each study within the RASA Program is assigned a single Professional Paper number beginning with Professional Paper 1400.

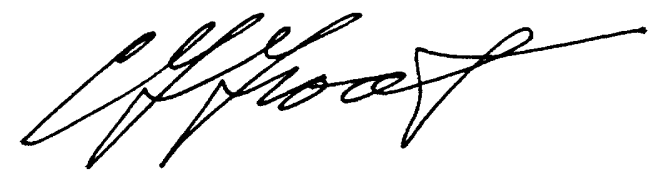

Charles G. Groat

Director 



\section{CONTENTS}

\begin{tabular}{|c|c|c|}
\hline & Page & \\
\hline$\ldots \ldots \ldots \ldots . . . . \mathrm{I}$ & III & Discharge . \\
\hline Abstract... & A1 & Ground-water development ..... \\
\hline Introduction ... & 2 & Regional ground-water flow ....... \\
\hline Purpose and scope & 2 & Regional flow model................ \\
\hline Physical setting & 4 & 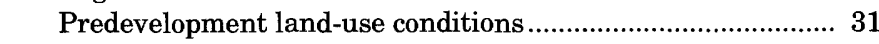 \\
\hline Hydrogeologic framework & 6 & 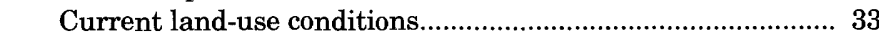 \\
\hline Geologic setting................... & 6 & Effects of historical water-development practices ................ \\
\hline Sedimentary units & 8 & Effects of potential water-management alternatives ...................... \\
\hline 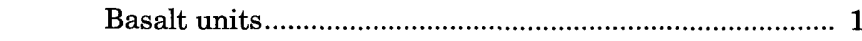 & 10 & Equilibrium conditions \\
\hline Imnaha and Picture Gorge Basalt. & 10 & Columbia Basin Irrigation Project expansion, 1983-85 \\
\hline Grande Ronde Basalt . & 11 & pumpage \\
\hline 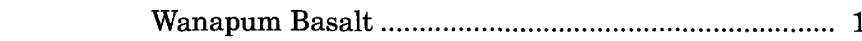 & 11 & Columbia Basin Irrigation Project expansion, reduced \\
\hline 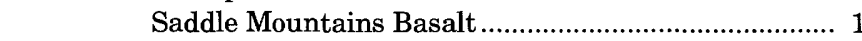 & 11 & pumpage \\
\hline Structural features & 12 & Ground-water quality \\
\hline Aquifer system & 12 & Water-quality characteristics..................................... \\
\hline Hydraulic characteristics ............................................ 1 & 13 & 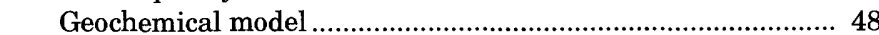 \\
\hline Flow system & 16 & 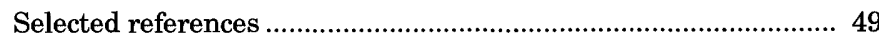 \\
\hline Recharge... & 22 & \\
\hline
\end{tabular}

\section{ILLUSTRATIONS}

FIGURES 1-3A. Maps showing:

1. Location of Columbia Plateau aquifer system, physiographic subprovince boundaries, and major physiographic features

2. Relation of extent of the Columbia River Basalt Group to the Columbia Plateau Regional Aquifer-

System Analysis study area and the hydrologic study area ..................................................................... 5

3A. Generalized surficial geology for the Columbia Plateau ..............................................................

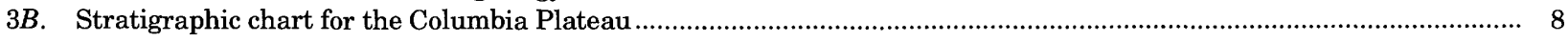

4.-12. Maps showing:

4. Major geologic structures within the Columbia Plateau..................................................................... 9

5. Water-table altitude and direction of ground-water flow for the overburden aquifer, representing conditions during spring 1983 , for selected areas ........................................................................... 17

6. Water-level contours and direction of ground-water flow for the Saddle Mountains unit, spring 1985........... 19

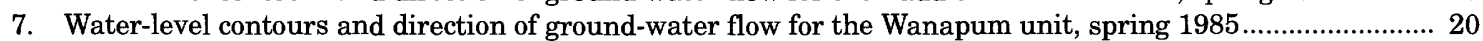

8. Water-level contours and direction of ground-water flow for the Grande Ronde unit, spring 1985 ................ 21

9. Location of 53 basins, or zones, for which recharge was estimated using a daily deep-percolation model....... 23

10. Distribution of estimated recharge for current (1980's) land-use conditions...................................................25

11. Distribution of estimated discharge for current (1980's) land-use conditions ..............................................2 27

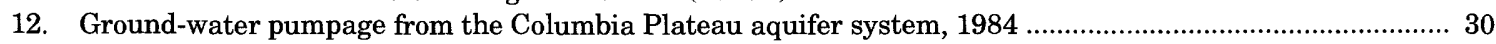

13.-14. Schematic diagrams showing:

13. The model-calculated water budget for predevelopment (1850's) land use conditions, Columbia Plateau aquifer system

14. The model-calculated water budget for current (1980's) land-use conditions, Columbia Plateau aquifer system.

15. Map showing model-calculated water-level changes in the Wanapum unit from predevelopment to present (1980's) ..... 36

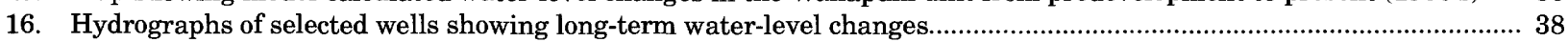

17. Map showing calculated water-level changes in the Wanapum unit from 1985 to equilibrium conditions, based on current water-management strategies. 


\section{TABLES}

TABLF 1. Selected hydrogeologic information for the Columbia Plateau aquifer system

2. Hydraulic characteristics of hydrogeologic units in the Columbia Plateau aquifer system, derived from the regional ground-water-flow model...

3. Summary of estimated recharge and data used for predevelopment and current land-use conditions, Columbia Plateau aquifer system.....

4. Ground-water pumpage by study unit from the Columbia Plateau, Washington, Oregon, and Idaho, 1945 to 1984

5. Calculated water budget for the predevelopment and time-averaged simulations for the Columbia Plateau aquifer system.. 28

6. Calculated water budget for the predevelopment and time-averaged simulations for layers in the gound-water model of the Columbia Plateau aquifer system...

7. Model-calculated ground-water discharge, estimated recharge, and average streamflows for drainage basins with

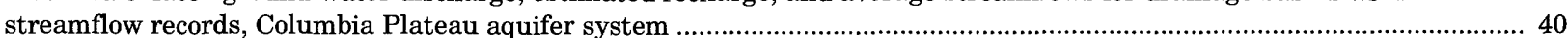

8. Model-calculated ground-water discharge to selected stream reaches, Columbia Plateau aquifer system........................... 41

9. Model-calculated changes in the regional ground-water flow system resulting from simulation of potential watermanagement alternatives, Columbia Plateau aquifer system ...

10. Summary of selected water chemistry information for the three basalt units, Columbia Plateau aquifer system .

\section{CONVERSION FACTORS AND VERTICAL DATUM}

\begin{tabular}{rll}
\hline Multiply & By & To obtain \\
\hline inch (in.) & 25.4 & millimeter \\
foot $(\mathrm{ft})$ & 0.3048 & meter \\
mile $(\mathrm{mi})$ & 1.609 & kilometer \\
acre & 0.4047 & hectare \\
square foot $\left(\mathrm{ft}^{2}\right)$ & 0.0929 & square meter \\
square mile $\left(\mathrm{mi}^{2}\right)$ & 2.59 & square kilometer \\
cubic mile $\left(\mathrm{mi}^{3}\right)$ & 4.168 & cubic kilometer \\
inch per year $(\mathrm{in} / \mathrm{yr})$ & 25.4 & millimeter per year \\
acre-foot $(\mathrm{acre}-\mathrm{ft})$ & 0.001233 & cubic hectometer \\
foot per mile $\left(\mathrm{ft} / \mathrm{mi}^{3}\right)$ & 0.3048 & meter per mile \\
foot per year $(\mathrm{ft} / \mathrm{yr})$ & 0.3048 & meter per year \\
foot per day $(\mathrm{ft} / \mathrm{d})$ & 0.3048 & meter per day \\
foot per second $(\mathrm{ft} / \mathrm{s})$ & 0.3048 & meter per second \\
square foot per second $(\mathrm{ft} / \mathrm{s})$ & 0.0929 & square meter per second \\
cubic foot per second $(\mathrm{ft} / \mathrm{s})$ & 0.02832 & cubic meter per second \\
gallon per minute $\left(\mathrm{gal} / \mathrm{min}^{3}\right)$ & 0.6308 & liter per second \\
ton & 0.9072 & megagram \\
pound per square inch $\left(\mathrm{lb} / \mathrm{in} .^{2}\right)$ & 70.3 & gram per square centimeter \\
pound per cubic inch $\left(\mathrm{lb} / \mathrm{in} .^{3}\right)$ & 27.68 & gram per cubic centimeter
\end{tabular}

to change degrees Fahrenheit $\left({ }^{\circ} \mathrm{F}\right)$ to degrees Celsius $\left({ }^{\circ} \mathrm{C}\right):{ }^{\circ} \mathrm{C}=5 / 9\left({ }^{\circ} \mathrm{F}-32\right)$

to change degrees Celsius $\left({ }^{\circ} \mathrm{C}\right)$ to degrees Fahrenheit $\left({ }^{\circ} \mathrm{F}\right):{ }^{\circ} \mathrm{F}=\left(9 / 5{ }^{\circ} \mathrm{C}\right)+32$

Sea Level: In this report "sea level" refers to the National Geodetic Vertical Datum of 1929 (NGVD of 1929)— a geodetic datum derived from a general adjustment of the first-order level nets of both the United States and Canada, formerly called "Sea Level Datum of 1929". 


\title{
REGIONAL AQUIFER-SYSTEM ANALYSIS-COLUMBIA PLATEAU
}

\author{
SUMMARY OF THE COLUMBIA PLATEAU \\ REGIONAL AQUIFER-SYSTEM ANALYSIS, \\ WASHINGTON, OREGON, AND IDAHO
}

\author{
BY J.J. VACCARO
}

\begin{abstract}
In 1982, the U.S. Geological Survey began a study of the Columbia Plateau aquifer system as part of its Regional Aquifer-System Analysis program. This report summarizes the results of the Columbia Plateau Regional Aquifer-System Analysis.

The study area, for which most of the physiographic, climatic, cultural, economic, and geologic information were presented in a series of reports, covers about 50,600 square miles of the 63,200 square miles underlain by the Columbia River Basalt Group. The study area for the hydrologic analysis covers about 32,700 square miles of the study area.

The Columbia Plateau aquifer system includes, from youngest to oldest: (1) the overburden, a collective term used in this study for all materials overlying the Columbia River Basalt Group; (2) a minor amount of sediment interlayered with the basalt; and (3) a large thickness of basalt belonging to the Columbia River Basalt Group, which is the most extensive and hydrologically important geologic unit in the aquifer system. This unit consists of five formations; the Saddle Mountains, Wanapum, and Grande Ronde Basalts are the principal formations of the aquifer system. Prebasalt rocks that underlie the plateau are the lower boundary to the aquifer system. The basaltic lavas make up more than 99 percent of the volume of the aquifer system. These basalts have an average thickness of 3,300 feet and an estimated maximum thickness of about 16,000 feet.

The aquifer system has been divided into three confining units and four aquifer units. The three confining units are the Saddle MountainsWanapum interbed, the Wanapum-Grande Ronde interbed, and the prebasalt rocks. The four aquifer units are the overburden aquifer, the Saddle Mountains unit, the Wanapum unit, and the Grande Ronde unit.
\end{abstract}

ABSTRAC
The overburden materials consist of fluvial consolidated to unconsolidated deposits of lacustrine, volcanic, and eolian origin whose lithology ranges from clay to gravels and shale to conglomerate. Most of these deposits generally have a much larger hydraulic conductivity than the basalts and, where saturated, make up a water-table aquifer called the overburden aquifer.

The Saddle Mountains Basalt constitutes less than 2 percent of the volume of the basalts, and, depending on geographic location, it overlies the Saddle Mountains-Wanapum interbed, the Wanapum Basalt, or the Grande Ronde Basalt. The Saddle Mountains Basalt and its intercalated sediments is called the Saddle Mountains unit.

A sedimentary interbed, the Saddle Mountains-Wanapum interbed, is commonly present between the Wanapum Basalt and the overlying Saddle Mountains Basalt and is considered a confining unit for this study. The Wanapum Basalt and its intercalated sediments (called the Wanapum unit) range in thickness from 0 to 1,300 feet and compose about 6 percent of the volume of the basalts.

A sedimentary interbed, the Wanapum-Grande Ronde interbed, underlies part of the Wanapum Basalt and overlies part of the Grande Ronde Basalt. This unit is considered a confining unit for this study. The Grande Ronde Basalt underlies most of the plateau and constitutes more than 85 percent of the volume of the basalts. This formation and. its intercalated sediments is called the Grande Ronde unit. For modeling and descriptive purposes, this unit has been divided into the upper and lower Grande Ronde. The prebasalt "basement" rocks are considered the base of the regional flow system and are called the basement confining unit.

For the overburden aquifer, lateral hydraulic conductivity values derived from specific-capacity data range from $2.9 \times 10^{-7}$ to $1.7 \times 10^{-1}$ foot per second, and regional values derived from the ground-water flow model range from $5.0 \times 10^{-7}$ to $1.3 \times 10^{-2}$ foot per second. Lateral hydraulic conductivity values derived from specific-capacity data for the basalt units range from $5.8 \times 10^{-8}$ to $6.1 \times 10^{-2}$ foot per second and values from the ground-water model range from $1.0 \times 10^{-6}$ to $1.0 \times 10^{-4}$ foot per second. Model-derived vertical hydraulic conductance values range from $4.5 \times 10^{-13}$ to $1.0 \times 10^{-5}$ foot per second per foot. Estimates of vertical hydraulic conductivity were calculated using the vertical hydraulic conductance values and thickness of units. The estimated median value of the vertical hydraulic conductivity of the overburden aquifer is about $2.1 \times 10^{-5}$ foot per second, and of the basalt, about $1.5 \times 10^{-8}$ foot per second. Calculated ground-water velocities range from $10^{-4}$ to 20 feet per day. The median velocity in the overburden aquifer is about 2 feet per day, and in the basalt units about 0.2 foot per day.

Ground-water movement in the overburden aquifer is from uplands to discharge points along stream courses. The potentiometric surface in the basalt units, where they are not overlain by younger units, roughly parallels the land surface, and movement of water is toward surface-drainage features. The water movement in the basalt units also follows the regional dip of the basalt, and in structurally complex areas the water moves downward from the axis of anticlines toward structural lows in synclines. Water in the uppermost basalt flow is unconfined and becomes semiconfined-to-confined with depth. Over most of the plateau, the vertical component of flow is generally downward, except in the proximity of discharge areas.

The long-term estimate of recharge for predevelopment (1850's) conditions is about 6,566 cubic feet per second $(4,750,000$ acre-feet or 2.72 inches per year) and for current (1980's) conditions is about 10,205 cubic feet per second $(7,385,000$ acre-feet or 4.24 inches per year). Discharge from the ground-water system, excluding pumpage, is mainly 
to surface-water features and to springs and seeps along canyon and coulee walls.

Ground-water pumpage for the Columbia Plateau was about 56,000 acre-feet in 1945, 178,000 acre-feet in 1960, and increased to a peak of about 940,000 acre-feet by 1979. About 828,278 acre-feet of water was pumped from the aquifer system in 1984 from an estimated 3,500 high-capacity wells. Between 85 and 90 percent of the pumped water was used to irrigate nearly 500,000 acres.

Water levels have risen to near land surface under about 1.2 million irrigated acres due to the application and infiltration of surface water. The largest rises are in the Columbia Basin Irrigation Project, where rises have exceeded 300 feet. Water-level declines resulting from ground-water pumping for irrigation began in the 1960's. The declines continue today and have exceeded 200 feet in some parts of the central plateau.

A ground-water flow model was constructed for predevelopment and current land-use conditions. Regional flow for current land-use conditions was simulated by using a time-averaged approach. Simulation indicates that from predevelopment to current conditions, recharge has increased about 3,640 cubic feet per second because of surface-water irrigation. An additional 187 cubic feet per second of water was obtained from loss in aquifer storage during 1983-85. The increase has been balanced by an increase in leakage to rivers $(1,050$ cubic feet per second), leakage to drains (1,650 cubic feet per second), and ground-water pumpage (1,135 cubic feet per second). Most of the increase in recharge enters the overburden aquifer $(3,083$ cubic feet per second).

The changes in distribution and rates of recharge and pumpage through time have caused changes in water levels. The median waterlevel rise in the overburden aquifer has been about 12 feet, which has resulted in the saturation of about 32 cubic miles of sediments (an increase of water in storage of about 10 million acre-feet) throughout an additional area of about 1,600 square miles. Declines in the overburden have been local and small. There has been a median rise of about 20 feet (average of 65 feet) in the Saddle Mountains unit, which has saturated about 23 cubic miles of the unit (an increase of water in storage of about 1.6 million acre-feet) throughout an additional area of about 839 square miles. Water-level declines have been relatively small and local. Water levels in the Wanapum unit have risen more than 300 feet, with a median of 10 feet. Declines in the Wanapum unit range from 1 to more than 200 feet and the median is about 9 feet. The largest declines have been in the central part of the plateau in Washington; on the southern slope of Horse Heaven Hills; near Umatilla, Oreg.; and in the Walla Walla River basin. In the upper Grande Ronde, water-level rises have a median of about 14 feet, and declines a median of about 6 feet. The water-level changes in this unit have been in excess of 200 feet in some locations. The largest rises have occurred in the Quincy basin as a result of surface-water irrigation, and the largest declines have been in the central plateau in Washington and near Umatilla, Oreg.

The model was used to simulate the long-term changes in the regional flow system resulting from continuation of current (1980's) water-development practices. Under these practices, the overburden aquifer generally would be unaffected, and the basalt aquifers would experience declines generally less than 200 feet. The effects would be largest in the Wanapum unit, where declines would extend over 400 square miles, and next largest in the Saddle Mountains unit. Declines in the Grande Ronde unit would not be as large or as widespread and generally would be less than 75 feet. The areas most affected would be in the central plateau in Washington; near Butter Creek, Oreg.; and on the Horse Heaven Hills. Additionally, parts of the Saddle Mountains unit and Wanapum unit may desaturate.

Four simulations were done to estimate the effects of the proposed expansion of the Federal Columbia Basin Irrigation Project, which receives water from the Columbia River. For each of the two phases of the proposed expansion, pumpage was held constant at 1984-85 rates, and pumpage was reduced proportionately according to expansion area. Water-level rises of more than 200 feet would occur in part of the aquifer system underlying and adjacent to the expansion area. Addi- tional recharge to the aquifer system resulting from the infiltration of the applied surface water was estimated to be about 974 cubic feet per second. The expansion would result in resaturation of areas that were calculated to become desaturated under current water-development practices. Significant rises would cover a broad area extending over some 600 square miles. The study unit most affected by the expansion would be the Wanapum unit. Water levels over a broad area would be near or at land surface under this management strategy, and thus a regional drain system probably would be needed.

Ground water in the basalt units is generally of good quality and suitable for most uses. The dominant water type in the three basalt units is calcium magnesium bicarbonate; sodium bicarbonate is the next most prevalent type, and calcium magnesium sulfate chloride is the least prevalent type. Sodium bicarbonate waters typically are in deeper downgradient locations, indicating that sodium concentrations in the ground water increase with ground-water residence time. Nitrogen concentrations greater than 2.0 milligrams per liter are found in water in basalt in areas where the overburden aquifer is thin and where surface water is used for irrigation. Concentrations of nitrogen greater than 10 milligrams per liter have been found in water from the overburden aquifer in areas of surface-water irrigation.

\section{INTRODUCTION}

The Columbia Plateau aquifer system is located in the Columbia Plateau of central and eastern Washington, north-central and eastern Oregon, and a small part of northwestern Idaho (fig. 1). The aquifer system underlies an area of about $50,600 \mathrm{mi}^{2}$, and consists of a large thickness of Miocene basalt of the Columbia River Basalt Group, small thicknesses of Miocene sedimentary rocks interlayered with the basalt, and Miocene to Holocene sedimentary deposits overlying the basalt. The aquifer system is the major source of water for municipal, industrial, domestic, and irrigation uses. Concurrent with ground-water use, imported surface water is used for irrigation in several areas of the plateau. There are about 1.7 million acres of irrigated croplands and about 7.5 million acres of nonirrigated croplands on the Columbia Plateau. About 1.2 million acres of the irrigated croplands are irrigated using surface water and about 0.5 million acres are irrigated using ground water.

An estimated 1.5 million acres of rangeland could be cropped profitably if water supplies were available, and an additional 2.0 million acres of nonirrigated cropland could be converted to larger yield crops if water were available for irrigation. Conversely, the decline in water levels in much of the area of ground-water withdrawal threatens the continuation of the ground-water irrigation.

\section{PURPOSE AND SCOPE}

The U.S. Geological Survey initiated a Regional Aquifer-System Analysis (RASA) program in 1978 in response to congressional concerns about the availabil- 


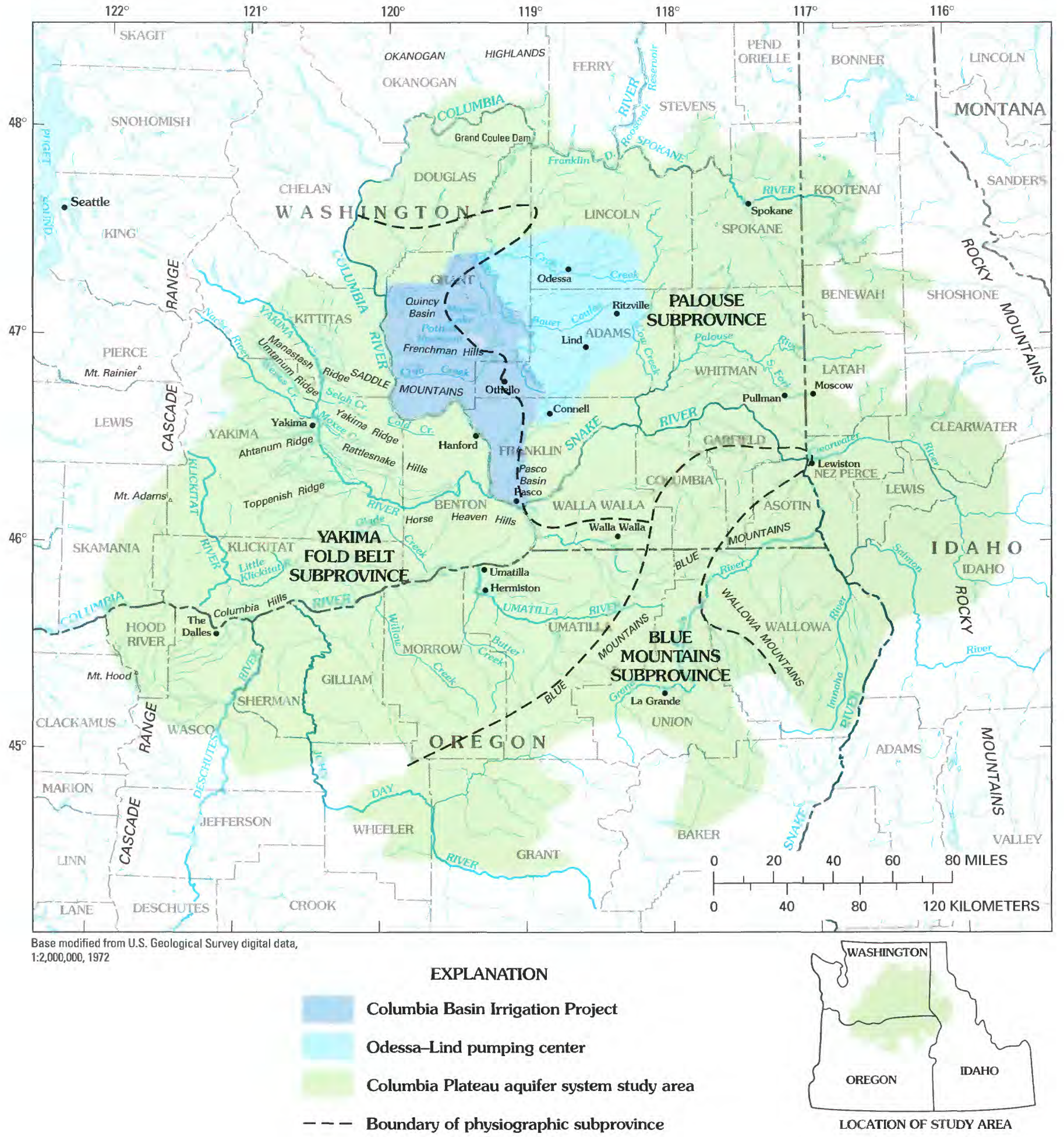

Figure 1.-Location of Columbia Plateau aquifer system, physiographic subprovince boundaries, and major physiographic features. 
ity and quality of the Nation's ground water (Sun, 1986). The Columbia Plateau aquifer system was chosen as one of the regional aquifers to be studied in this program. In order to meet the overall RASA program objectives, it was necessary to describe the following items for the Columbia Plateau: (1) the geologic framework, (2) hydrologic characteristics of individual hydrogeologic units, (3) the area's water budget, (4) the groundwater/surface-water flow system, and (5) the waterquality characteristics and water-rock interactions that occur in the study area. In order to provide the analytical capabilities necessary to assess management alternatives and to obtain a better understanding of the ground-water system, a numerical model that simulates ground-water movement was constructed.

This report, Chapter A of Professional Paper 1413, summarizes the results of the Columbia Plateau regional aquifer-system analysis. Chapter B (Whiteman and others, 1994) describes the physical, cultural, and economic setting, the geologic framework, the hydrologic characteristics of major hydrogeologic units, the components of the water budget, and the regional ground-water flow system, and presents a brief overview of the water-quality characteristics and geochemistry of the aquifer system. The hydrology of the regional aquifer system on the basis of simulating regional flow using a ground-water flow model is described in Hansen and others (1994) and Bauer and Hansen (in press). Steinkampf and Hearn (1996) describe the geochemistry of the aquifer system.

The RASA study area, for which most of the physiographic, climatic, cultural, economic, and geologic information were described in this study, covers about $50,600 \mathrm{mi}^{2}$ of the $63,200 \mathrm{mi}^{2}$ underlain by the Columbia River Basalt Group (fig. 2). The hydrologic study area (fig. 2), for which the hydrologic information was analyzed and presented, encompasses about $32,700 \mathrm{mi}^{2}$ of the RASA study area and is the boundary for the ground-water flow model.

The information collected and analyzed in the Columbia Plateau RASA is documented in 30 reports. These reports, prepared by the U.S. Geological Survey, are listed in the Selected References section at the end of this report and describe major components of the aquifer system. An overview of the Columbia Plateau RASA was described by Vaccaro (1986a; 1986b). The geologic framework for the Washington part of the study was described by Drost and Whiteman (1986), for the Oregon part of the study by Gonthier (1990), and for the complete study area by Drost and others (1990). The ground-water flow system and water-level changes were described by Bauer and others (1985), Whiteman (1986), and Lane and Whiteman (1989). Estimates of ground-water pumpage were made by Collins (1987),
Cline and Knadle (1990), and Cline and Collins (1992). Ground-water recharge and climatic variability were evaluated by Bauer and Vaccaro (1986; 1987a; 1987b; 1990), Vaccaro and Bauer (1987; 1990), and Vaccaro (1991). Nelson (1991) described the surface-water resources of the study area. Water-quality characteristics and geochemistry were evaluated by Hearn and others (1985), Steinkampf and others (1985), Steinkampf (1989), and Steinkampf and Hearn (1996). The construction and use of a regional ground-water flow model and a description of the hydrology of the study area were discussed by Bauer and Hansen (in press), Hansen (1993a; 1993b), and Hansen and others (1994). The description of the hydrology is for both predevelopment and current land-use conditions. Predevelopment land-use conditions are assumed to represent the 1850's, the latest period on the plateau without water-development practices. Current land-use conditions represent the period 1983-85. For the construction of the groundwater flow model, the predevelopment conditions were simulated as steady-state and the current conditions were simulated as time-averaged (1983-85). The basic data compiled, gathered, and analyzed during this study were documented by Lane (1988a and 1988b) and Wagner and Lane (1994).

\section{PHYSICAL SETTING}

The Columbia Plateau lies in the Columbia intermontane physiographic province (Freeman and others, 1945). It is bordered by the Cascade Range on the west, by the Okanogan Highlands on the north, and by the Rocky Mountains on the east; its southern boundary is defined by the extent of the Columbia River Basalt Group rather than by any physiographic feature (fig. 2). The Columbia Plateau is drained by the Columbia River and its major tributaries - the Snake, Yakima, John Day, Umatilla, Spokane, Klickitat, and Deschutes Rivers.

The Columbia Plateau is underlain everywhere by massive basalt flows with an estimated composite maximum thickness of about $16,000 \mathrm{ft}$ near its structural and topographic low near Pasco, Wash. The characteristics of the older rocks overlain by the Columbia River Basalt Group are distinguishable only at exposures in the ıhlands surrounding the plateau. Sedimentary deposits overlie the basalt over large areas of the plateau, exceeding $1,200 \mathrm{ft}$ in thickness in the Yakima River valley and 2,000 ft in the Grande Ronde valley near $\mathrm{La}$ Grande, Oreg.

The Columbia Plateau was divided into three informal physiographic subprovinces by Myers and Price (1979) - the Yakima Fold Belt, Blue Mountains, and Palouse subprovinces (fig. 1). The Yakima Fold Belt 


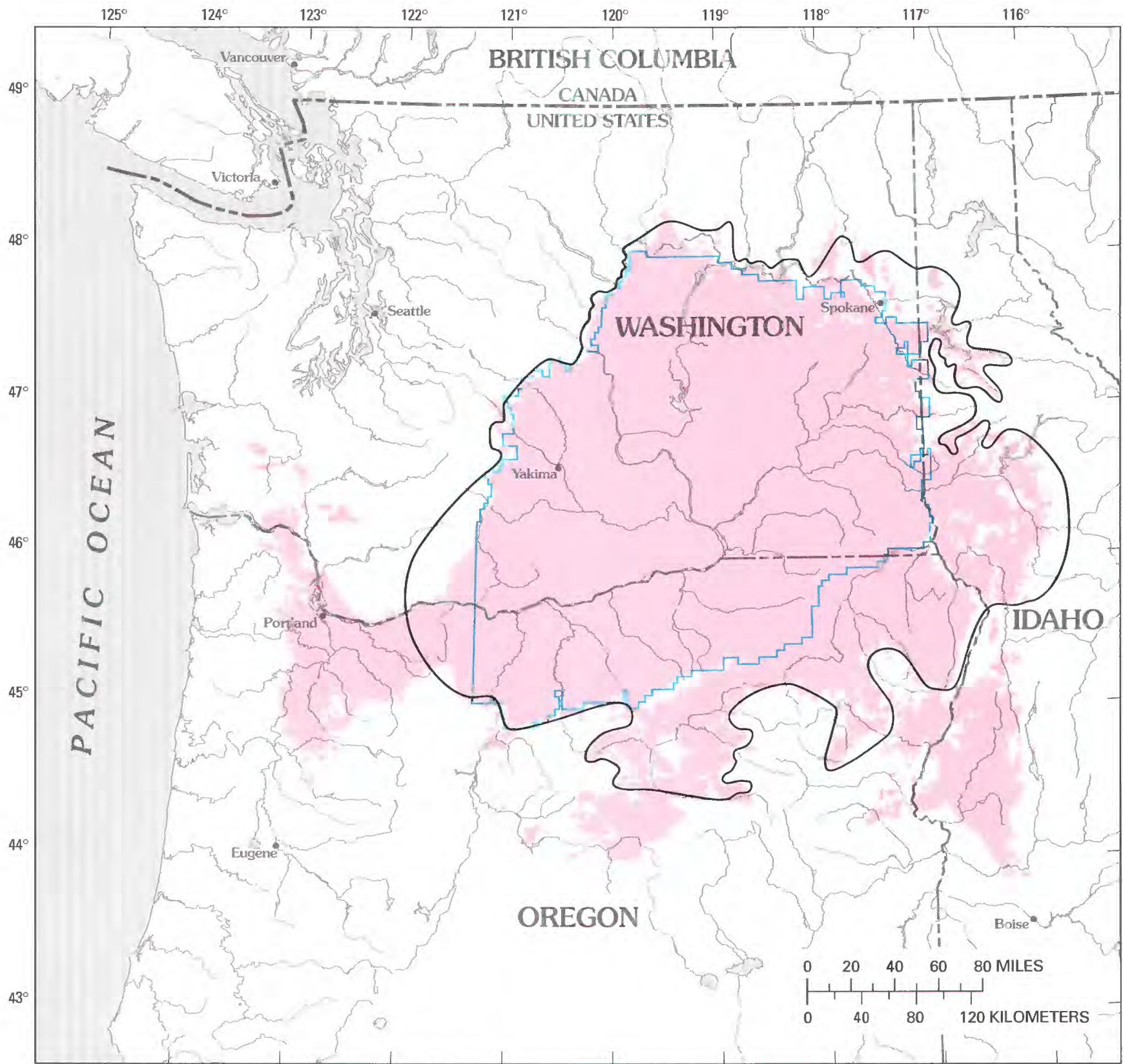

Base modified from U.S. Geological Survey digital data, 1:2,000,000, 1998, and Canadian Geological Survey digital data, 1:5,000,000, 1995

EXPLANATION

Columbia River Basalt Group

Boundary of Columbia Plateau Regional Aquifer-System Analysis study area

Boundary of hydrologic study area

FIGURE 2.-Relation of extent of the Columbia River Basalt Group to the Columbia Plateau Regional Aquifer-System Analysis study area and the hydrologic study area. 
includes most of the western half of the plateau north of the crest of the Blue Mountains, and is characterized by a series of ridges and basins. The Palouse subprovince occupies the northeast quarter of the plateau in Washington, north of the Blue Mountains, and extends eastward into Idaho. It consists of nearly undeformed basalt with a gentle southwest slope, on which a rolling topography of loessal hills is developed. The Blue Mountains subprovince comprises most of the Columbia Plateau in Oregon and Washington south and east of the Blue Mountains, including a series of folds extending a few miles into Idaho near Lewiston. It is characterized by higher plateaus, deeply dissected by many streams.

The topography in central Washington, referred to as the "channeled scablands," was produced during Pleistocene time. Catastrophic floods, resulting from the breakup of glacial ice dams impounding large lakes in western Montana and northern Idaho, carved spectacular erosional features into the basalt plateau. Floodwaters stripped away overlying sediments and plucked large blocks of basalt, leaving behind deep canyons and coulees, rugged cliffs and buttes, large gravel bars, and giant ripple marks measuring 20 to $30 \mathrm{ft}$ in height. Thick layers of sediment were deposited in low areas where floodwaters spread, slowed, and ponded.

The types and amounts of natural vegetation found on the Columbia Plateau are determined largely by precipitation and land-surface altitudes. Mean annual precipitation ranges from about 6 inches in the center of the study area to more than 45 inches in the surrounding forested mountains. In the central part of the plateau, where the land surface ranges from 350 to $2,000 \mathrm{ft}$ above sea level and the precipitation ranges from 6 to 15 inches per year, the vegetation is principally sagebrush and grasslands and there are few perennial streams. At higher altitudes $(2,000$ to $3,500 \mathrm{ft})$, vegetation is more typical of semiarid climates and includes both grasslands and forest. These areas generally receive from 15 to 25 inches of precipitation per year. Where altitudes range from 3,500 to $6,000 \mathrm{ft}$ and precipitation ranges from 25 to 50 inches per year, forest lands predominate and small perennial streams in deep canyons are common. Precipitation is greater in the Cascade Range to the west than at similar altitudes in the Blue Mountains to the southeast. The mountainous topography is typically rugged and steep with a patchwork of barren rock and conifer forests at the land surface.

The mean monthly precipitation is greatest in December or January and least in July (Nelson, 1991). Typically, 85 percent of the precipitation occurs from October through May. Approximately 38 percent of the total annual precipitation falls from November through January. Winter snowfall ranges from 8 to 20 inches in the central plateau and from 70 to 300 inches at higher altitudes in the Cascade Range and Blue Mountains.

The lowest mean monthly minimum temperatures range from $3^{\circ} \mathrm{C}$ in the low-lying areas to $-3^{\circ} \mathrm{C}$ in the higher altitudes, and the highest mean monthly maximum temperatures range from $19^{\circ} \mathrm{C}$ in the central plateau to $13^{\circ} \mathrm{C}$ in the mountainous areas. Mean daily temperature fluctuations range from $8^{\circ} \mathrm{C}$ in winter to $20^{\circ} \mathrm{C}$ in summer. The seasonal extremes of daily temperature vary by about $40^{\circ} \mathrm{C}$ between winter lows and summer highs.

\section{HYDROGEOLOGIC FRAMEWORK}

\section{GEOLOGIC SETTING}

The Columbia Plateau aquifer system includes, from youngest to oldest: (1) the overburden, a collective term used in this study for all materials (from Miocene to Holocene age) overlying the Columbia River Basalt Group; (2) a minor amount (in most areas) of Miocene sediment interlayered with the basalt; and (3) a large thickness of Miocene basalt belonging to the Columbia River Basalt Group. The Columbia River Basalt Group is the surficial geologic unit throughout 80 percent of the plateau (fig. $3 A$ ). Pre-Columbia River Basalt Group rocks underlie the plateau and are presumed to consist primarily of less permeable rocks that form the lower boundary to the aquifer system. These are sedimentary, igneous, and metamorphic rocks that range from the Precambrian through early Tertiary age. Little is known about the geologic nature and distribution of these rock types in the central plateau because few wells have been drilled through the basalt. However, the distribution of these older rocks is well defined along the margins of the plateau where the basalt thins and the older rocks are exposed or are at shallow depths.

Basaltic lavas that make up the bulk of the Columbia Plateau aquifer system were extruded over an interval of 12 million years during the Miocene Epoch between 17 and 6 million years ago, from north-northwest-trending fissures as much as 90 miles long, located chiefly in northeastern Oregon and southeastern Washington (Hooper, 1982; Swanson and others, 1975). Flows from these fissures covered about $63,200 \mathrm{mi}^{2}$ of eastern and parts of western Washington, northern Oregon, and western Idaho to an average total thickness of 3,300 ft. About 95 percent of the basalt was extruded in episodic eruptions during the first 3 million years of the 12-million-year interval.

Prebasalt topography in the fissure areas had considerable relief; early lava flows, therefore, filled narrow 


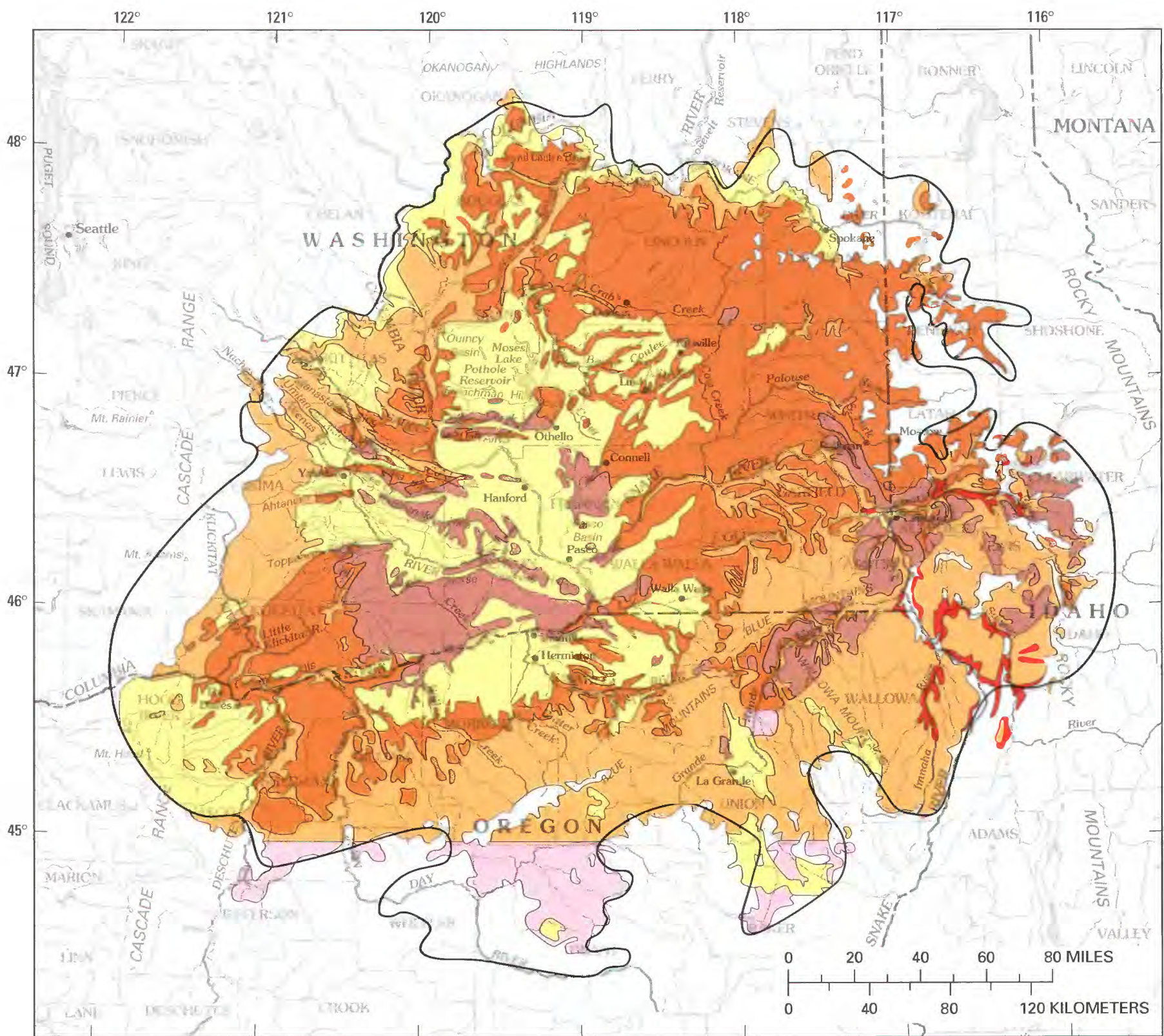

Base modified from U.S. Geological Survey digital data, 1:2,000,000, 1972

\section{EXPLANATION}

\section{Overburden}

Columbia River Basalt Group, undivided

Saddle Mountain Basalt

Wanapum Basalt

Grande Ronde Basalt

Imnaha Basalt
Boundary of Columbia Plateau aquifer system study area

Contact

FIGLRE 3A-Generalized surficial geology for the Columbia Plateau. (Modified from Drost and others, 1990). 


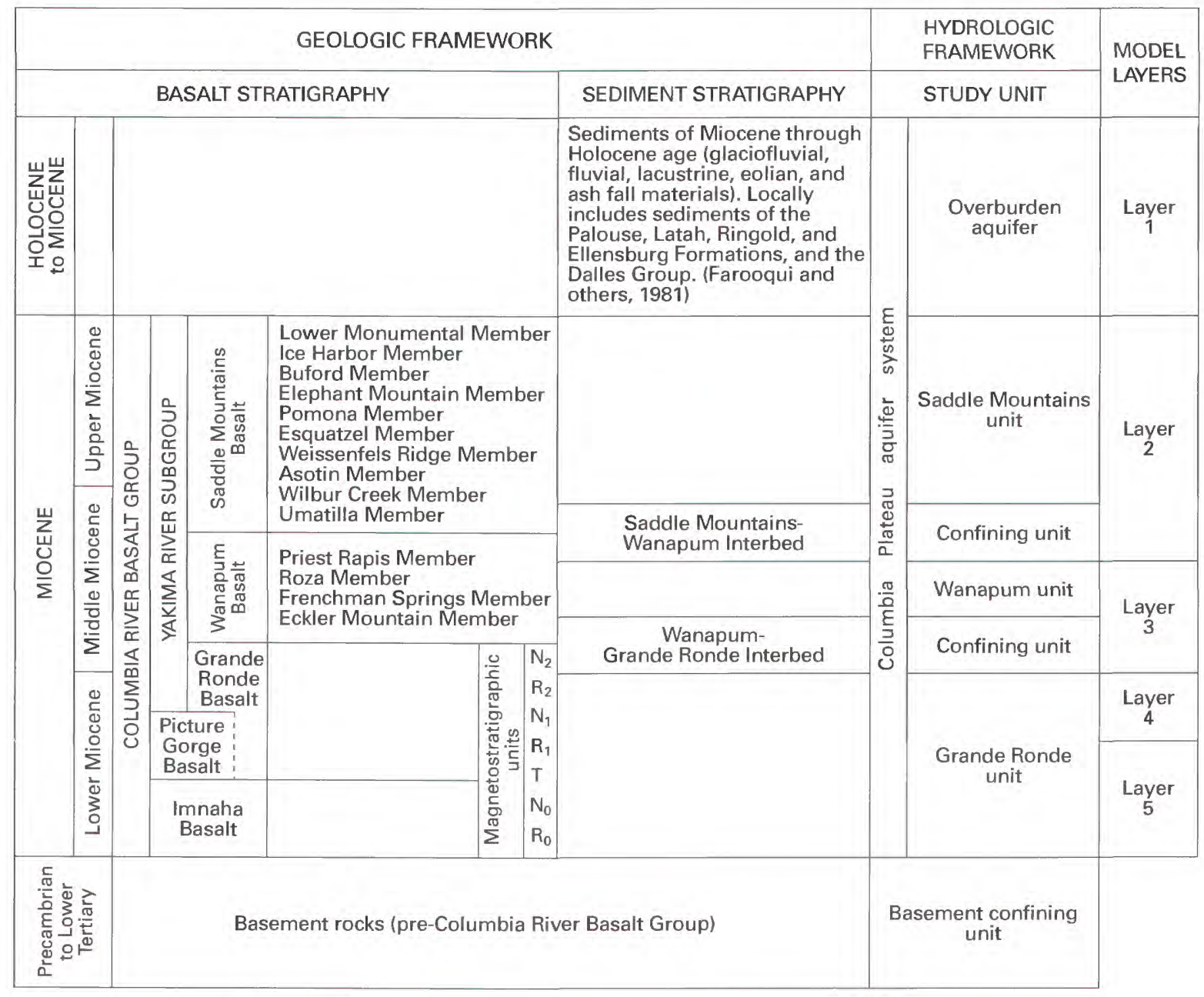

Figure 3B.-Stratigraphic chart for the Columbia Plateau (Modified from Drost and others, 1990). Magnetostratigraphic units: $\mathrm{N}$, normal polarity; $\mathrm{R}$, reverse polarity; $\mathrm{T}$, transition polarity; units numbered sequentially from oldest to youngest.

prebasalt valleys and gradually smoothed out the Miocene landscape. Later flows spread in thin sheets across a flat, west-sloping paleosurface having a few minor warps. It is likely that water was present on this paleosurface, and the interaction between the water and overriding molten lava caused rapid chilling and steam explosions that shattered the basalt and formed pillow lava complexes and structural irregularities.

Warping and folding of the plateau increased late in the eruptive cycle, forming the Frenchman Hills anticline, the Horse Heaven Hills anticline, the Dalles-Umatilla syncline, the Blue Mountains uplift, and numerous other geologic structures (fig. 4). Because these tectonic activities were mostly in the western and southern plateau, late basalt flows tended to be confined to the central part of the plateau and were restricted to narrow canyons in places near the plateau margin. These younger flows have been buried under sediments in many areas and are usually more continuous areally than older basalt flows, which have been thinned by erosion, cut by streams, and affected by tectonic folding, uplift, and faulting.

\section{SEDIMENTARY UNITS}

Sedimentary interbeds are more common in the younger basalt than in the older units, and were deposited in shallow lake basins on the warped basalt surface between eruptive phases. Eruption of basalt ceased some 6 million years ago, but folding, erosion, and deposition of sediments have continued. The Cascade Range has been the principal source of large quantities of sediments and volcaniclastics, which have been transported by air and water and deposited in adjacent areas. Thus, the greater thicknesses of overburden are in the western part of the study area near the Cascade Range. 


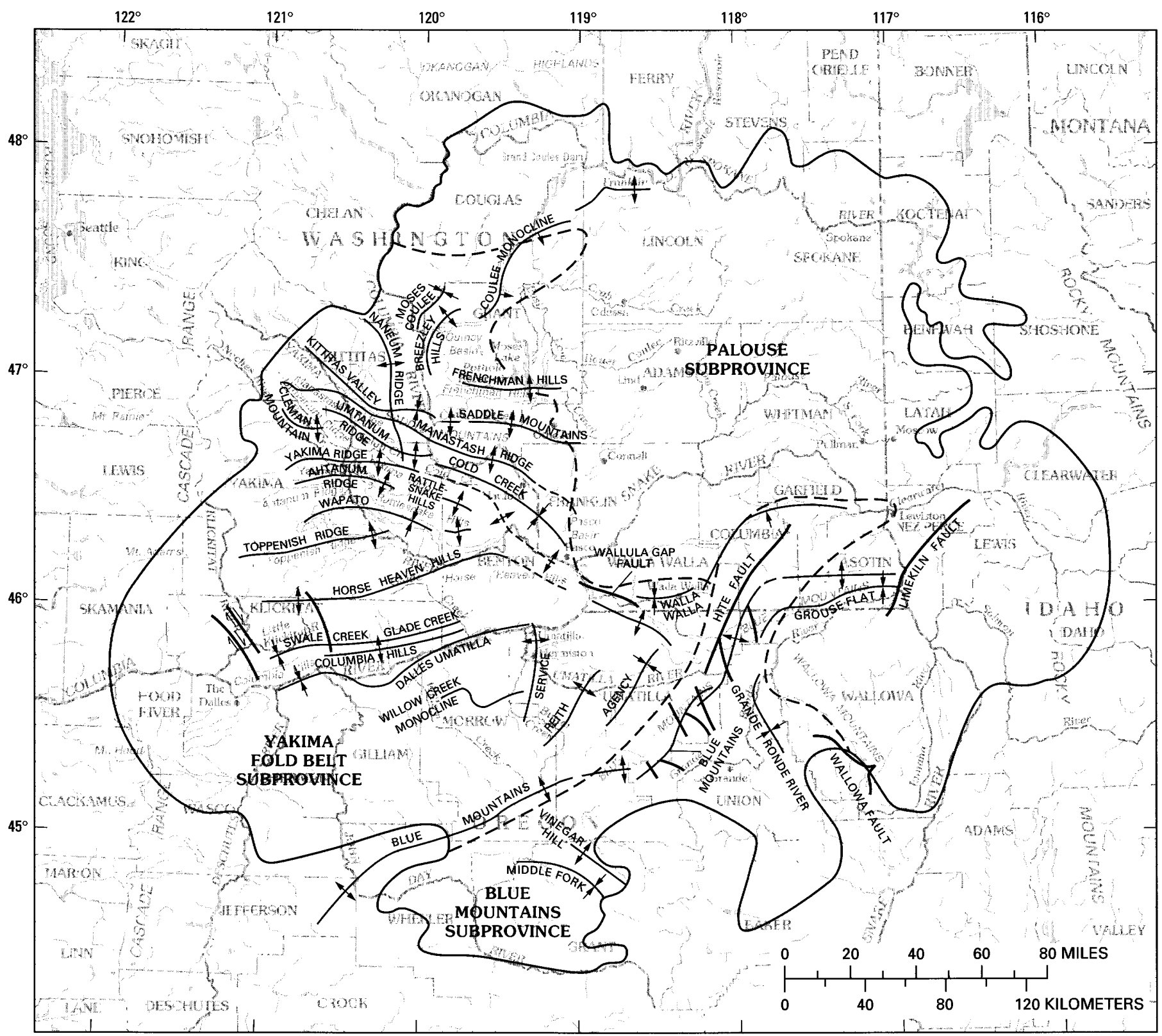

Base modified from U.S. Geological Survey digital data, 1:2,000,000, 1972

EXPLANATION

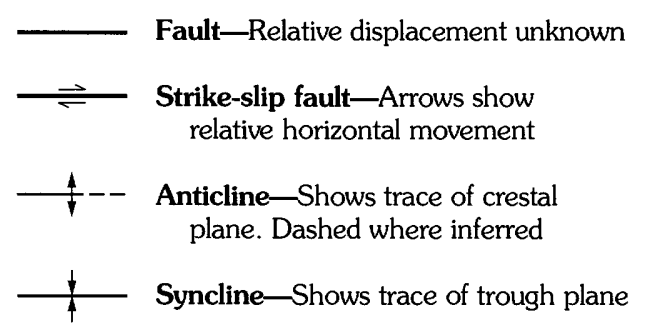

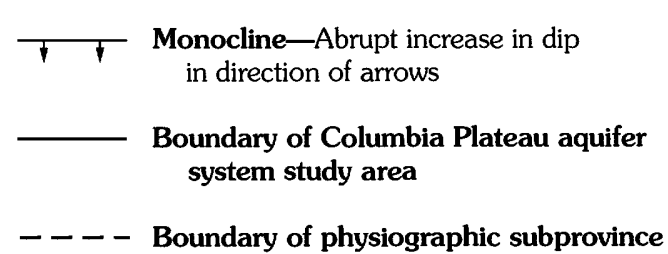

FIGURE 4.-Major geologic structures within the Columbia Plateau. (Modified from Drost and others, 1990). 
Overburden is a composite unit of all rock materials $50 \mathrm{ft}$ or greater in thickness that overlie the Columbia River Basalt Group, and is an important source of ground water. The thickness of the overburden ranges from 50 to more than $2,000 \mathrm{ft}$, and the thickest deposits occur in structural basins and in areas adjacent to the Cascade Range.

The overburden includes fluvial consolidated to unconsolidated deposits of lacustrine, volcanic, and eolian origin ranging from Miocene to Holocene age. The sediments and sedimentary rocks from the many different formations across the plateau are lithologically diverse, ranging from clay to gravels and shale to conglomerate. In Oregon, several of the major formations within the overburden have been named The Dalles Group by Farooqui and others (1981). Other major formations composing the overburden are the Ellensburg, Latah, Ringold, and Palouse.

Sedimentary deposits belonging to the Ellensburg Formation are interbedded with the basalt and also overlie it in the western and central parts of the plateau. They consist of weakly lithified fluvial sand and gravel with some lahars and sand, silt, and clay.

In the northeastern part of the plateau and within the Spokane River drainage, beds of the Latah Formation are interbedded with and overlie the basalt. These sediments consist mostly of finely laminated siltstone with some claystone, the composition of which reflects the pre-Columbia River Basalt granitic and metamorphic basement rocks of the region.

In the Walla Walla River, Quincy, and Pasco basins, the sediments overlying the basalt are part of the Ringold Formation. The Miocene-Pliocene Ringold Formation includes sediments of both fluvial and lacustrine origin. It is at least $500 \mathrm{ft}$ thick in these basins and consists predominantly of fine sand and silt, but sometimes includes a gravel-and-conglomerate facies.

Structural basins on the plateau margin south of the Columbia River in Oregon contain sediments that overlie the basalt and are folded with it. The sediments consist of coarse- to fine-grained fluvial deposits, lahars, and volcaniclastic materials that reflect source areas in the nearby uplands on the plateau margin.

The Grande Ronde valley in northeastern Oregon is a major graben, filled with more than 2,000 ft of fluviolacustrine deposits, interfingering alluvial fan deposits, and alluvial deposits.

The Cordilleran ice sheet that covered the northern and northwestern parts of the plateau left extensive deposits of till, stratified drift, and ice-contact materials, especially in the northern and northwestern parts of the plateau. Alpine glaciers from the Cascade Range and the Wallowa Mountains also reached the plateau margin and left deposits.
Catastrophic flooding of the Columbia Plateau took place during late Pleistocene time when ice dams in western Montana and northern Idaho were breached, allowing enormous volumes of water to flood what is now eastern and central Washington. Deposits formed during the floods were poorly sorted, clast-supported, and open-work gravels intermixed with sand and gravels. These flood-gravels were deposited by high-energy flood currents in and along scabland channels, in depositional basins, and in the Columbia River east of The Dalles. Slackwater deposits formed in peripheral areas of basins in the central part of the plateau. Slackwater deposits are interbedded silt and sand with a minor amount of gravel and are known as the Touchet Beds (Flint, 1938).

Eolian deposits of fine loess of Pleistocene age cover much of the plateau and reach thicknesses of as much as $250 \mathrm{ft}$, but generally are much thinner. The thickest deposits are found in the Palouse region in the eastern part of the study area and are part of the Palouse Formation. At least four different ages of loess deposits are present on the Columbia Plateau.

Unconsolidated alluvial deposits of Quaternary age occur along most major streams and consist of gravel, sand, silt, and clay. Dune-sand deposits of Quaternary age, consisting predominately of fine to medium windblown sand, are found in Oregon and in central Grant County in Washington.

\section{BASALT UNITS}

The thickest, most extensive, and hydrologically most important geologic unit in the Columbia Plateau aquifer system is the Columbia River Basalt Group, a unit that has been subdivided into five formations and numerous members (fig. $3 B$ ). The five formations, from oldest to youngest, are the Imnaha Basalt, Picture Gorge Basalt, Grande Ronde Basalt, Wanapum Basalt, and the Saddle Mountains Basalt. Of these, the principal formations in the Columbia Plateau aquifer system are part of the Yakima Basalt Subgroup of the Columbia River Basalt Group. The generalized occurrence of these three formations is shown on figure $3 A$, and the accompanying diagram, figure $3 B$, lists the members within each formation.

\section{Imnaha and Picture Gorge Basalt}

The Imnaha Basalt is found in northeastern Oregon and adjacent Washington and Idaho, where it is exposed chiefly in the valleys of the Imnaha, Snake, Salmon, and Clearwater Rivers (fig. 3A). The Picture Gorge Basalt is exposed only in north-central Oregon, mostly within the John Day basin south of the Blue 
Mountains uplift, where it is locally interlayered with Grande Ronde Basalt and is in part coeval with it.

The Imnaha and Picture Gorge Basalts are not considered important units in the regional aquifer system because of their limited extent and their occurrence at the edges of the plateau areas. In this study, the Picture Gorge Basalt has not been distinguished from the rest of the Columbia River Basalt Group and is included within either the Grande Ronde Basalt or the undivided category on plate figure $3 \mathrm{~A}$.

\section{Grande Ronde Basalt}

The Grande Ronde Basalt underlies most of the plateau and pinches out at its margin. It is the most extensive of the three major formations, constituting 85 to 88 percent of the total volume of the Columbia River Basalt Group (Reidel, 1982; Tolan and others, 1987). The Grande Ronde Basalt consists of perhaps as many as 131 individual flows (Tolan and others, 1987). Few drill holes on the plateau penetrate the total basalt thickness; thus, little is known about the complete thickness of the Grande Ronde Basalt except at the edges of the plateau where the basalts are relatively thin and pinch out against older rocks. In the center of the plateau, the total thickness of pre-Wanapum basalts exceeds $14,000 \mathrm{ft}$ (Drost and others, 1990).

Sedimentary interbeds within the Grande Ronde are rare, generally only a few feet thick, and of limited lateral extent. Where present, they vary in grain size from clay to gravel. Interbeds apparently are more common near the plateau margin.

The top of this formation is marked by a zone of weathering and (or) a sedimentary interbed separating it from the overlying Wanapum or Saddle Mountains Basalts. Over most of the area, this sedimentary interbed is the Vantage Member of the Ellensburg Formation; however, in the northeastern part of the plateau, the sedimentary interbed in the same stratigraphic position is assigned to the Latah Formation (Swanson and others, 1979c). Minor nomenclature problems of this type were avoided in this study by referring to the interbeds according to their typical stratigraphic position within the basalt; for example, the WanapumGrande Ronde interbed. The Wanapum-Grande Ronde interbed is most extensive and thickest in the northern part of the plateau, where it ranges from 0 to $100 \mathrm{ft}$ locally, but averages about $25 \mathrm{ft}$ (Drost and others, 1990). It consists chiefly of claystone and siltstone, with minor sand and gravel and sandstone beds. It is thinner to the south, and in the central plateau little is known about its extent. A thin saprolite commonly marks the interval in areas where the interbed is absent.
Wanapum Basalt

The Wanapum Basalt overlies the Grande Ronde Basalt and is the second most voluminous and extensive basalt formation in the Columbia River Basalt Group. It composes about 6 percent of the total volume of the basalts. Along part of the northeastern and eastern edge of the plateau, the Wanapum Basalt overlies the prebasalt rock material. The Wanapum Basalt includes about 33 separate basalt flows (Tolan and others, 1987). Sedimentary interbeds are more abundant in the Wanapum Basalt than in the Grande Ronde Basalt, but generally are thin and localized.

The combined thickness of the Wanapum Basalt flows and any interbedded sediments ranges between 0 and 1,300 ft, with the greatest thickness in the Pasco basin. The Wanapum Basalt is exposed extensively or is covered by a veneer of sedimentary deposits in the northeastern and southern parts of the plateau. In the central and western part, it is overlain by younger geologic units.

A sedimentary interbed-the Saddle MountainsWanapum interbed-is commonly present between the Wanapum Basalt and the overlying Saddle Mountains Basalt. This interbed is generally equivalent to the Beverly Member of the Ellensburg Formation. The Saddle Mountains- Wanapum interbed consists chiefly of clay, silt, claystone, or siltstone. Lesser amounts of sand, sand and gravel, and sandstone are reported; available data do not indicate any pattern to the distribution of these coarse-grained materials. Thickness of the Saddle Mountains-Wanapum interbed averages about $50 \mathrm{ft}$, but generally ranges between 0 and $200 \mathrm{ft}$ (Drost and others, 1990).

Saddle Mountains Basalt

The Saddle Mountains Basalt, the youngest basalt formation in the Columbia River Basalt Group, consists of 10 members (Swanson and others, 1979d) and about 19 flows (Tolan and others, 1987). Of these members, only three are regional in extent and, therefore, important components of the regional aquifer system. The Saddle Mountains Basalt constitutes less than 2 percent of the total volume of the Columbia River Basalt Group. The Saddle Mountains Basalt was extruded during a period of accelerated tectonic activity, erosion, waning volcanism, and deposition of sedimentary interbeds between eruption periods of the major members. Each of the major basalt members generally consists of only one or two basalt flows. Depending on geographic location, the Saddle Mountains Basalt overlies either the Saddle Mountains-Wanapum interbed, the Wanapum Basalt, or the Grande Ronde Basalt. 
The thickness of the Saddle Mountains Basalt flows, together with any interbedded sediments, ranges from 0 to more than $800 \mathrm{ft}$. Maximum thickness occurs in the Yakima valley and the area south of Hanford, Wash. In one area in Oregon, the interbeds make up about 50 percent of the total thickness; however, this is not the case in most of the area.

\section{STRUCTURAL FEATURES}

Geologic structures within the plateau are diverse and range from simple homoclines to sharp folds with structural relief of up to several thousand feet. Major faults generally are associated with anticlinal folds and range from steep normal faults to low-angle reverse faults. The structural complexity of the Columbia Plateau (fig. 4) is indicated by the major geologic structures (Drost and others, 1990). Complex structure is a major geologic control on the movement of ground water within the aquifer system.

The Palouse subprovince is structurally simple and is underlain by basalt flows that dip less than 5 degrees toward the southwest. Superimposed on the southwesterly dipping basalt are a few broad, open, northwesttrending folds with amplitudes of only a few tens of feet.

The dominant feature of the Yakima Fold Belt subprovince is a series of narrow, asymmetrical anticlinal ridges, east-west to northwesterly trending and east and southeasterly plunging, that are generally separated by broad, flat-floored synclinal valleys. From south to north the most prominent anticlinal ridges are the Columbia Hills, Horse Heaven Hills, Toppenish Ridge, Ahtanum Ridge-Rattlesnake Hills, Yakima Ridge, Umtanum Ridge, and Manastash Ridge.

In Oregon south of the Columbia Hills, the basalt dips toward the axis of The Dalles-Umatilla syncline, which roughly follows the south shore of the Columbia River and forms a broad, asymmetrical synclinal basin. The south limb of the syncline is formed by gently north-dipping basalt that forms the north flank of the Blue Mountains anticline. Pre-Columbia River Basalt Group rocks that form the core of the Blue Mountains are exposed in a few places.

The eastern part of the Blue Mountains subprovince was the vent area for much of the Columbia River Basalt Group flows. It is a rugged uplifted region consisting of remnants of a plateau surface and deeply dissected canyons with up to a few thousand feet of local relief. The most prominent structural feature is the broad-crested Blue Mountains anticline and a belt of asymmetrical folds that diverge easterly from its northeastern end. The crestal area of the anticline is crossed by numerous northwest-trending high-angle normal faults, as well as lineaments with no apparent displacement.

Numerous linear, northwest-southeast-trending, en echelon basalt feeder-dike complexes have been identified in the southeastern part of the plateau in both Washington and Oregon. Similar dike complexes are believed to be covered by younger basalt in these areas and possibly elsewhere. Although they are not strictly a geologic structure, their effects on the movement of ground water are similar to those of some geologic structures.

\section{AQUIFER SYSTEM}

The primary factors controlling the occurrence, movement, availability, and quality of ground water in the Columbia Plateau aquifer system are the hydrologic characteristics of the geologic units underlying it, the climate, and water-supply development practices. In order to address these factors within such a complex aquifer system, it was necessary to conceptualize and relate the geologic and hydrologic frameworks into a simpler system, or conceptual model. This concept then provided a basis for investigating the hydraulic characteristics, the ground-water recharge and discharge, and ground-water chemistry, and for modeling the groundwater flow in the regional aquifer system.

Most of the lowlands of the plateau are basins in which the Columbia River Basalt Group is overlain by sediments and sedimentary rocks. These rocks range from shales and clays to conglomerate and gravel, but generally are coarse grained and permeable in their upper sections and finer grained and less permeable at depth. They transmit water readily and constitute a water-table aquifer where they are saturated. The average hydraulic conductivity can be several orders of magnitude larger than that of the basalt. The sediments and sedimentary rocks forming the overburden are considered a single unit, the overburden aquifer.

The movement of water through basalt is governed by several factors related to the individual basalt flows. These factors include the topographic surface over which basalts flowed; the erosional processes that occurred before, during, and after extrusion; presence of water on the paleosurface; the deposition of interbeds; tectonic activity; and diagenetic processes. As a result, basalt is an extremely heterogeneous aquifer unit that transmits water most readily through the broken vesicular and scoriaceous interflow zones that commonly make up 5 to 10 percent of the thickness of an individual basalt flow. The interflow zones are separated by the less transmissive and more coherent flow centers consisting of the entablature and colonnade in 
which the fractures are more or less vertical. Lateral ground-water movement in the entablature and colonnade is probably negligible when compared with the volume of water that moves laterally through the interflow zones. This is because movement of water in the entablature and colonnade is controlled by fractures and joint systems, whereas movement of water in the interflow zones is controlled by primary features such as flow breccia, clinkers, and vesicles. Vertical movement of ground water between interflow zones is much less per unit area than lateral movement, but is quite large over the region. Vertical movement of ground water varies because of the structure of individual lava flows and the hydraulic characteristics of the interbeds.

The lithology of sedimentary interbeds between basalt flows within a formation varies from shales to sand and gravels. Except in the Saddle Mountains Basalt, most interbeds within formations are of limited extent. The interbeds between formations are fairly extensive laterally, but are thin when compared with basalt formations. These interbeds can be locally transmissive and function as aquifers, but in general they probably impede vertical movement of water. Waterlevel and well-log data suggest that the interbeds generally can be regarded as semiconfining to locally confining layers that transmit small quantities of water laterally.

The conceptual ground-water model developed for the study area divides the aquifer system into seven hydrogeologic units--the overburden aquifer, three aquifer units in the permeable basalt rock, two confining units, and the basement confining unit (see fig. $3 B$ ). For the conceptual model, the three basalt aquifer units are the Saddle Mountains, Wanapum, and Grande Ronde Basalts and their intercalated sediments. In the southeastern part of the study area, the Imnaha Basalt and any intercalated sediments are included with the Grande Ronde unit. These basalt units are distinguished from basalt formations by being referred to in this study as "units"; for example, the Wanapum Basalt and interbeds are referred to as the Wanapum unit. The confining units are equivalent to the Saddle MountainsWanapum and the Wanapum-Grande Ronde interbeds. The basement confining unit consists of the prebasalt "basement" rocks that generally have much lower permeabilities than the basalts and are considered the base of the regional flow system.

The grouping of several overburden formations and 100 or more individual basalt flows (representing large thicknesses) into a system of seven hydrogeologic units greatly limits the conceptual and numerical model's ability to deal with local phenomena. Part of this limitation was met by further dividing the Grande Ronde unit into an upper Grande Ronde and a lower Grande
Ronde. The upper Grande Ronde was defined as about the top 2,000 feet of the Grande Ronde unit. This division facilitated numerical modeling of the system and provided a better understanding and description of the explored basalt system. Therefore, information is presented in places in the following sections for the upper and lower Grande Ronde rather than the Grande Ronde unit. Selected hydrogeologic information for the aquifer system is presented in table 1 .

\section{HYDRAULIC CHARACTERISTICS}

Estimates of the range and distribution of lateral hydraulic conductivity, transmissivity, vertical hydraulic conductance, specific yield, storage coefficient, and stream-leakance coefficients were made for this study because these estimates are required for understanding the occurrence, movement, quality, and availability of ground water. The lateral hydraulic conductivity analyzed in this study is a depth-integrated average value, representative over a study-unit thickness. Similarly, the vertical conductance represents the effective combined vertical hydraulic conductivity of two units and interbeds divided by a representative thickness.

Lateral hydraulic conductivity values for each study unit initially were estimated from drillers' specificcapacity data using the methods presented by Ferris and others (1962) and by Theis (1963). In this method, a vertically averaged lateral hydraulic conductivity for the depth of well penetration is derived, and the value includes the effects of the vertical movement of water. That is, estimated lateral hydraulic conductivities represent the integrated effects of water moving both horizontally and vertically through the entire open interval of a well, including all parts of a lava flow or flows and any intercalated sediments for the basalt units.

Initial estimates of lateral hydraulic conductivity of the overburden aquifer derived from specific-capacity tests were generally for basins. The values for the eastern part of the study area were represented by typical values for loess, the dominant sediments. The specificcapacity data were used in the ground-water model to derive regional estimates, which range from about $2.9 \times 10^{-7}$ to $1.7 \mathrm{ft} / \mathrm{s}$ and have a median lateral hydraulic conductivity of about $2.8 \times 10^{-3} \mathrm{ft} / \mathrm{s}$. Fifty percent of the values about the median lie in the range $5.2 \times 10^{-4}$ to $1.2 \times 10^{-2} \mathrm{ft} / \mathrm{s}$, and only 3 of the 871 values were greater than $4.0 \times 10^{-1} \mathrm{ft} / \mathrm{s}$. The model-derived values range from $5.0 \times 10^{-7}$ to $1.3 \times 10^{-2} \mathrm{ft} / \mathrm{s}$ and have a median of about $5.0 \times 10^{-4} \mathrm{ft} / \mathrm{s}$. Table 2 presents some descriptive statistics of the regional values derived from groundwater modeling. 
TABLE 1.-Selected hydrogeologic information for the Columbia Plateau aquifer system

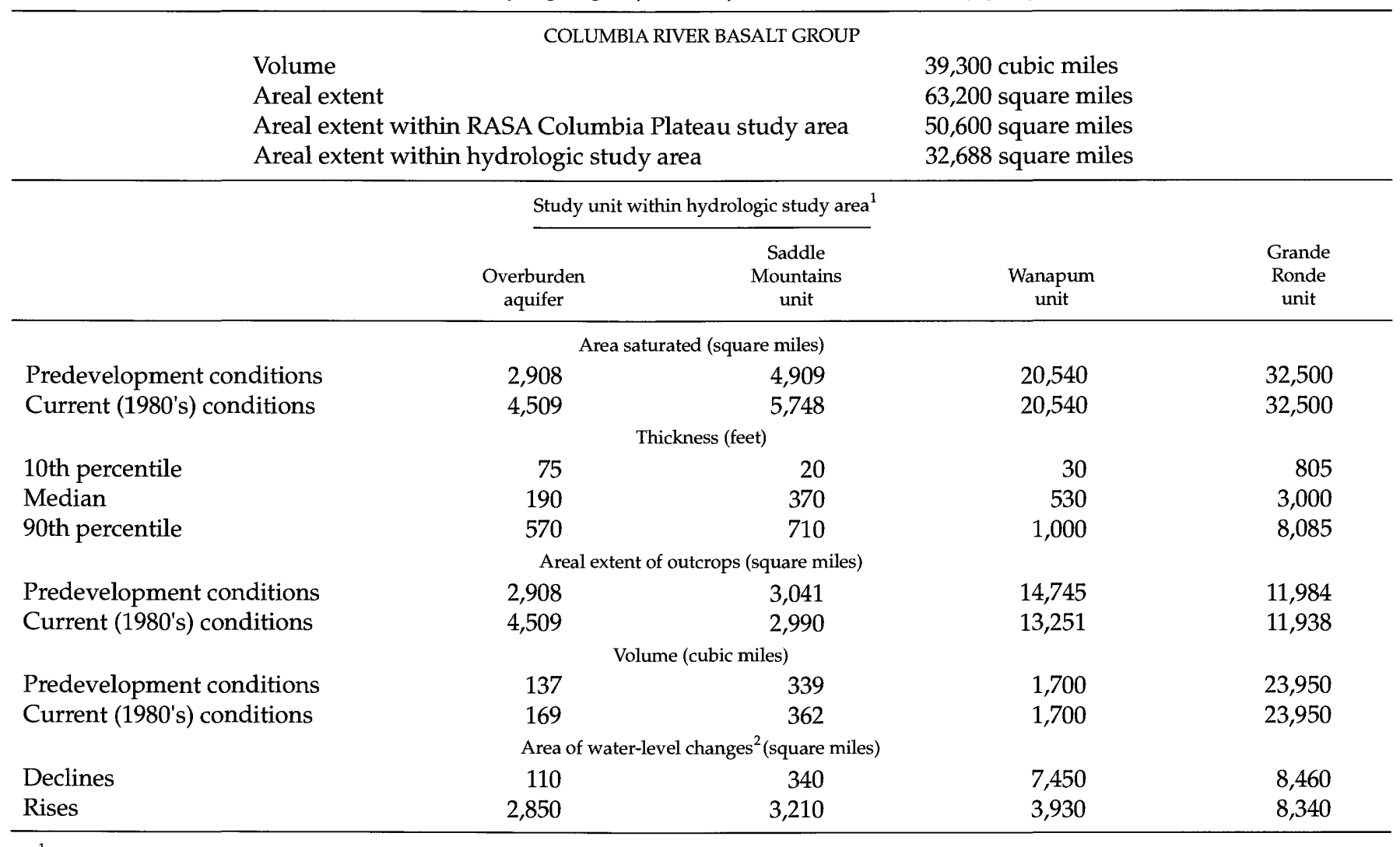

${ }^{1}$ Based on data gridded for model grid system that is discussed later in this report.

${ }^{2}$ Model-calculated changes of more than 10 feet from predevelopment to current conditions. Calculated changes are described later in this report.

In general, aquifer tests of the cased wells in the basalt yield site-specific values of hydraulic conductivity that are representative of a single zone. To obtain an understanding of both the range in hydraulic conductivity values for the entire basalt sequence in the study area and of the effects of geologic structures, numerous aquifer tests in widely distributed cased wells would be needed. This need could not be met because most wells finished in the Columbia River Basalt Group are uncased, aquifer-test data are sparse and inconsistent, and there is a lack of information about the effects of vertical leakage. Therefore, specific-capacity data were used to estimate initial hydraulic conductivity values. The estimated values, about a thousand for all three basalt units, then were used in the ground-water flow model to derive regional estimates.

Estimates derived from specific-capacity data for the basalt values range from $5.8 \times 10^{-8}$ to $6.1 \times 10^{-2} \mathrm{ft} / \mathrm{s}$ and have a median of $5.9 \times 10^{-5} \mathrm{ft} / \mathrm{s}$. Seventy-five percent of the lateral hydraulic conductivity values are less than $3.0 \times 10^{-4} \mathrm{ft} / \mathrm{s}$, and 75 percent are larger than $1.2 \times 10^{-5} \mathrm{ft} /$ s. The Saddle Mountains, Wanapum, and Grande Ronde units have median lateral hydraulic conductivity values of $2.8 \times 10^{-5}, 6.0 \times 10^{-5}$, and $5.7 \times 10^{-5} \mathrm{ft} / \mathrm{s}$, respec- tively. The smaller median hydraulic conductivity of the Saddle Mountains unit is attributed to the thicker and more numerous intercalated sedimentary interbeds, generally lacking in the Wanapum and Grande Ronde units. Model-derived values for the basalt units (table 2) range from $1.0 \times 10^{-6}$ to $1.0 \times 10^{-4} \mathrm{ft} / \mathrm{s}$. Median values for the Saddle Mountains and Wanapum units are $1.6 \times 10^{-5}$ and $3.0 \times 10^{-5} \mathrm{ft} / \mathrm{s}$, respectively. The model-derived median lateral hydraulic conductivity is $1.6 \times 10^{-5} \mathrm{ft} / \mathrm{s}$ for the upper Grande Ronde and $1.4 \times 10^{-5} \mathrm{ft} / \mathrm{s}$ for the lower Grande Ronde.

The wide range in hydraulic conductivity reflects the heterogeneous nature of the basalt. The largest calculated hydraulic conductivity values are probably due to local geologic structure, thickening of interflow zones, thinning of individual lava flows, or to the presence of pillow lava complexes (Swanson, 1967) that increase the hydraulic conductivity. Wells for which many of these large values were estimated are close to wells for which small hydraulic conductivity values were estimated, demonstrating the localized occurrence of these values. Observed physical variations in exposed lava flows suggest that, within a single flow, the lateral and vertical hydraulic conductivity values 
TABLE 2.-Hydraulic characteristics of hydrogeologic units in the Columbia Plateau aquifer system, derived from the regional ground-water flow model

\begin{tabular}{|c|c|c|c|c|}
\hline \multirow[b]{2}{*}{ Hydrogeologic unit } & \multicolumn{4}{|c|}{$\begin{array}{l}\text { Lateral hydraulic conductivity, in feet per second } \\
\text { (values in parentheses derived from specific-capacity data) }\end{array}$} \\
\hline & Median. & Mean & Minimum & Maximum \\
\hline Overburden aquifer & $\begin{array}{c}4.98 \times 10^{-4} \\
\left(2.78 \times 10^{-3}\right)\end{array}$ & $\begin{array}{l}1.14 \times 10^{-3} \\
\left(9.53 \times 10^{-2}\right)\end{array}$ & $\begin{array}{l}4.98 \times 10^{-7} \\
\left(2.86 \times 10^{-7}\right)\end{array}$ & $\begin{array}{c}1.27 \times 10^{-2} \\
\left(1.73 \times 10^{0}\right)\end{array}$ \\
\hline Saddle Mountains unit & $\begin{array}{r}1.62 \times 10^{-5} \\
\left(2.76 \times 10^{-5}\right)\end{array}$ & $\begin{array}{r}1.48 \times 10^{-5} \\
\left(6.48 \times 10^{-5}\right)\end{array}$ & $\begin{array}{r}1.97 \times 10^{-5} \\
\left(8.12 \times 10^{-5}\right)\end{array}$ & $\begin{array}{r}3.01 \times 10^{-5} \\
\left(2.19 \times 10^{-2}\right)\end{array}$ \\
\hline Wanapum unit & $\begin{array}{r}3.01 \times 10^{-5} \\
\left(6.02 \times 10^{-5}\right)\end{array}$ & $\begin{array}{c}3.73 \times 10^{-5} \\
\left(7.60 \times 10^{-4}\right)\end{array}$ & $\begin{array}{l}1.01 \times 10^{-6} \\
\left(8.12 \times 10^{-8}\right)\end{array}$ & $\begin{array}{r}9.03 \times 10^{-5} \\
\left(6.07 \times 10^{-2}\right)\end{array}$ \\
\hline $\begin{array}{l}\text { Grande Ronde unit } \\
\text { Upper Grande Ronde }\end{array}$ & $\begin{array}{l}1.61 \times 10^{-5} \\
\left(5.70 \times 10^{-5}\right)\end{array}$ & $\begin{array}{c}2.62 \times 10^{-5} \\
\left(5.77 \times 10^{-4}\right)\end{array}$ & $\begin{array}{l}1.50 \times 10^{-6} \\
\left(5.78 \times 10^{-8}\right)\end{array}$ & $\begin{array}{r}9.98 \times 10^{-5} \\
\left(2.92 \times 10^{-2}\right)\end{array}$ \\
\hline Lower Grande Ronde & $1.45 \times 10^{-5}$ & $2.30 \times 10^{-5}$ & $1.10 \times 10^{-6}$ & $7.44 \times 10^{-5}$ \\
\hline & \multicolumn{4}{|c|}{ Transmissivity, in feet squared per second } \\
\hline Hydrogeologic unit & Median & Mean & Minimum & Maximum \\
\hline Overburden aquifer & $5.79 \times 10^{-2}$ & $2.13 \times 10^{-1}$ & $2.60 \times 10^{-5}$ & $3.12 \times 10^{0}$ \\
\hline Saddle Mountains unit & $3.70 \times 10^{-3}$ & $5.29 \times 10^{-3}$ & $2.80 \times 10^{-5}$ & $2.29 \times 10^{-2}$ \\
\hline Wanapum unit & $8.45 \times 10^{-3}$ & $1.55 \times 10^{-2}$ & $5.00 \times 10^{-5}$ & $1.08 \times 10^{-1}$ \\
\hline $\begin{array}{l}\text { Grande Ronde unit } \\
\text { Upper Grande Ronde }\end{array}$ & $1.97 \times 10^{-2}$ & $4.25 \times 10^{-2}$ & $4.80 \times 10^{-4}$ & $1.84 \times 10^{-1}$ \\
\hline Lower Grande Ronde & $3.11 \times 10^{-2}$ & $8.51 \times 10^{-2}$ & $5.52 \times 10^{-4}$ & $4.80 \times 10^{-1}$ \\
\hline \multirow[t]{2}{*}{ All units combined } & $3.85 \times 10^{-2}$ & $1.35 \times 10^{-1}$ & $4.80 \times 10^{-4}$ & $3.48 \times 10^{0}$ \\
\hline & \multicolumn{4}{|c|}{ Vertical hydraulic conductance, in feet per second per foot } \\
\hline Hydrogeologic unit & Median & Mean & Minimum & Maximum \\
\hline Overburden aquifer & $2.63 \times 10^{-8}$ & $1.25 \times 10^{-6}$ & $2.00 \times 10^{-12}$ & $1.01 \times 10^{-5}$ \\
\hline Saddle Mountains unit & $2.12 \times 10^{-11}$ & $1.09 \times 10^{-9}$ & $5.00 \times 10^{-13}$ & $3.54 \times 10^{-8}$ \\
\hline Wanapum unit & $6.02 \times 10^{-12}$ & $3.66 \times 10^{-10}$ & $5.00 \times 10^{-13}$ & $2.70 \times 10^{-8}$ \\
\hline $\begin{array}{l}\text { Grande Ronde unit } \\
\text { Upper Grande Ronde }\end{array}$ & $4.98 \times 10^{-11}$ & $4.10 \times 10^{-11}$ & $4.5 \times 10^{-13}$ & $4.98 \times 10^{-11}$ \\
\hline
\end{tabular}

should exhibit a large range. For example, cascading water in many uncased wells is attributed to the relative ease with which water moves horizontally along interflow zones. Thus, the hydraulic conductivity in interflows is mainly due to primary features such as flow breccia, vesicles, and clinkers rather than to the fracture assemblage; whereas, in the entablature and colonnade, the hydraulic conductivity is mainly due to fractures and joint systems developed during cooling processes and tectonic activity.

Modeling studies (F. A. Packard, U.S. Geological Survey, written commun., 1987; Davies-Smith and others, 1988; William Meyer, U.S. Geological Survey, written commun., 1985) suggest that, within a basalt unit, the vertically averaged lateral hydraulic conductivity for some geologic structures, such as faults, may be as small as $10^{-9}$ to $10^{-8} \mathrm{ft} / \mathrm{s}$. There are two possible expla- nations for this--the offsetting of interflow zones through faulting, which produces low-conductivity fault breccia and gouge material at that interface (as described by Newcomb, 1965, 1969; and Stearns, 1942), and the closing of pore space through deposition of secondary minerals. Values derived from the application of the ground-water model in this study suggest that, for some structures, typically faults and fault-associated anticlines, lateral conductivity can be reduced by about two orders of magnitude.

Transmissivities of the study units and of the total aquifer system were estimated for the area within the ground-water model boundaries. The transmissivities of the total aquifer system range from $4.8 \times 10^{-4}$ to 3.5 $\mathrm{ft}^{2} / \mathrm{s}$ (square feet per second), with an estimated median of about $3.8 \times 10^{-2} \mathrm{ft}^{2} / \mathrm{s}$ (table 2). The estimated median values for the five aquifers, from youngest to 
oldest, are $5.8 \times 10^{-2}, 3.7 \times 10^{-3}, 8.4 \times 10^{-3}, 2.0 \times 10^{-2}$, and $3.1 \times 10^{-2} \mathrm{ft}^{2} / \mathrm{s}$; maximum values range from $2.3 \times 10^{-2}$ to $3.1 \mathrm{ft}^{2} / \mathrm{s}$.

Vertical hydraulic conductivity values of the basalts are largely unknown. Estimates made during numerical ground-water-modeling studies (MacNish and Barker, 1976, p.5; Prych, 1983, p.35; F. A. Packard, U.S. Geological Survey, written commun., 1987) range from $2 \times 10^{-12}$ to $5 \times 10^{-9} \mathrm{ft} / \mathrm{s}$. The range of the ratio of horizontal to vertical hydraulic conductivity has been estimated to be from about 5,000:1 to 100:1 (Hansen and others, 1994; F. A. Packard, U.S. Geological Survey, written commun., 1987; Lum and others, 1990; A. J. Hansen, U.S. Geological Survey, written commun., 1986). Vertical hydraulic conductivity values were not estimated directly in this study. Instead, vertical hydraulic conductance was estimated. These values were derived during model calibration on the basis of proportionality factors, thickness, and lateral hydraulic conductivity. These regionalized values integrate the hydraulic characteristics of all overburden sediments and basalt flows and intercalated sediments, and generally approximate an effective vertical hydraulic conductivity divided by a representative thickness. Table 2 shows that the median values are, from youngest to oldest, $2.6 \times 10^{-8}, 2.1 \times 10^{-11}$, $6.0 \times 10^{-12}$, and $5.0 \times 10^{-11} 1 / \mathrm{s}$ (feet per second per foot, or per second); basalt values range from $4.5 \times 10^{-13}$ to $3.5 \times 10^{-8} 1 / \mathrm{s}$, and overburden values range from $2.0 \mathrm{x}$ $10^{-12}$ to $1.0 \times 10^{-5} 1 / \mathrm{s}$.

Vertical hydraulic conductivity estimates based on the model-derived values of vertical conductance showed that the median value for the overburden aquifer is about $2.1 \times 10^{-5} \mathrm{ft} / \mathrm{s}$, or about an order of magnitude smaller than the lateral hydraulic conductivity. The vertical hydraulic conductivity of the basalt units varied widely and has a median of about $1.5 \times 10^{-8} \mathrm{ft} / \mathrm{s}$. This median value is, in turn, about three orders of magnitude smaller than the median lateral conductivity of basalt units. The larger vertical hydraulic conductivity values estimated during this study are probably due to the following reasons: (1) Unlike the previous investigations, most of the Palouse subprovince was included in this study, and the northeastern part encompasses most of the structurally unaffected basalt area; (2) the total thickness of the basalt units was modeled in this study, resulting in a smaller effective vertical hydraulic conductance and a larger effective vertical hydraulic conductivity; (3) the boundaries in this study generally extended to the basalt's lateral extent or an equivalent no-flow boundary; and (4) better hydraulic head control were available from more wells in the Wanapum and Grande Ronde units allowed for improved assessment of vertical gradients.
The potential range in the storage coefficient was estimated for the basalt units on the basis of selected published values of storage coefficients for the Columbia Plateau and on model simulations. Values for the overburden aquifer were estimated from selected published values.

The estimated storage coefficient values for the overburden materials range from 0.0002 to 0.2 and generally represent the specific yield. Storage coefficient values for the basalt range from $10^{-7}$ to $10^{-2}$ and represent a range of aquifer conditions including confined conditions where the values approach the expansibility of water, leaky artesian conditions, and water-table conditions with low porosity. Analysis of ground-water-level declines in conjunction with ground-water pumpage suggests that long-term regional values are about the same for all basalt units and probably range from 0.005 to 0.05 . A value of 0.04 was used as the estimate for the time-averaged ground-water model simulation.

Stream-leakance coefficients represent proportionality factors for estimating the flux of water between the aquifer system and streams. These factors are multiplied by the difference in hydraulic head between a stream and the unit the stream resides in, to obtain an estimate of the flux. The coefficients, derived and regionalized during model calibration, range from 0.1 to $11.0 \mathrm{ft}^{2} / \mathrm{s}$. The median coefficient was about $1 \mathrm{ft}^{2} / \mathrm{s}$, and about 70 percent of the coefficients were equal to the median.

\section{FLOW SYSTEM}

The occurrence, movement, and availability of ground water in the Columbia Plateau are controlled by the aquifer system's geometry and hydraulic characteristics, and the distribution and rates of ground-water recharge and discharge, including changes caused by water-development practices. A description of the regional flow system and how it relates to these factors has been discussed by Bauer and others (1985), Whiteman (1986), Lane and Whiteman (1989), Whiteman and others (1994), and Hansen and others (1994).

The altitude of the water table in the overburden aquifer for Washington and Oregon is shown on figure 5. The overburden materials compose a water-table aquifer in the Quincy, Pasco, Yakima River, Walla Walla River, and Umatilla River basins. The direction of ground-water flow is toward discharge points along surface-water features in these basins. Water in the overburden aquifer is in direct hydraulic connection with water in the immediately underlying basalt unit. Within the U.S. Bureau of Reclamation's Columbia Basin Irrigation Project (CBIP), much of the overburden 


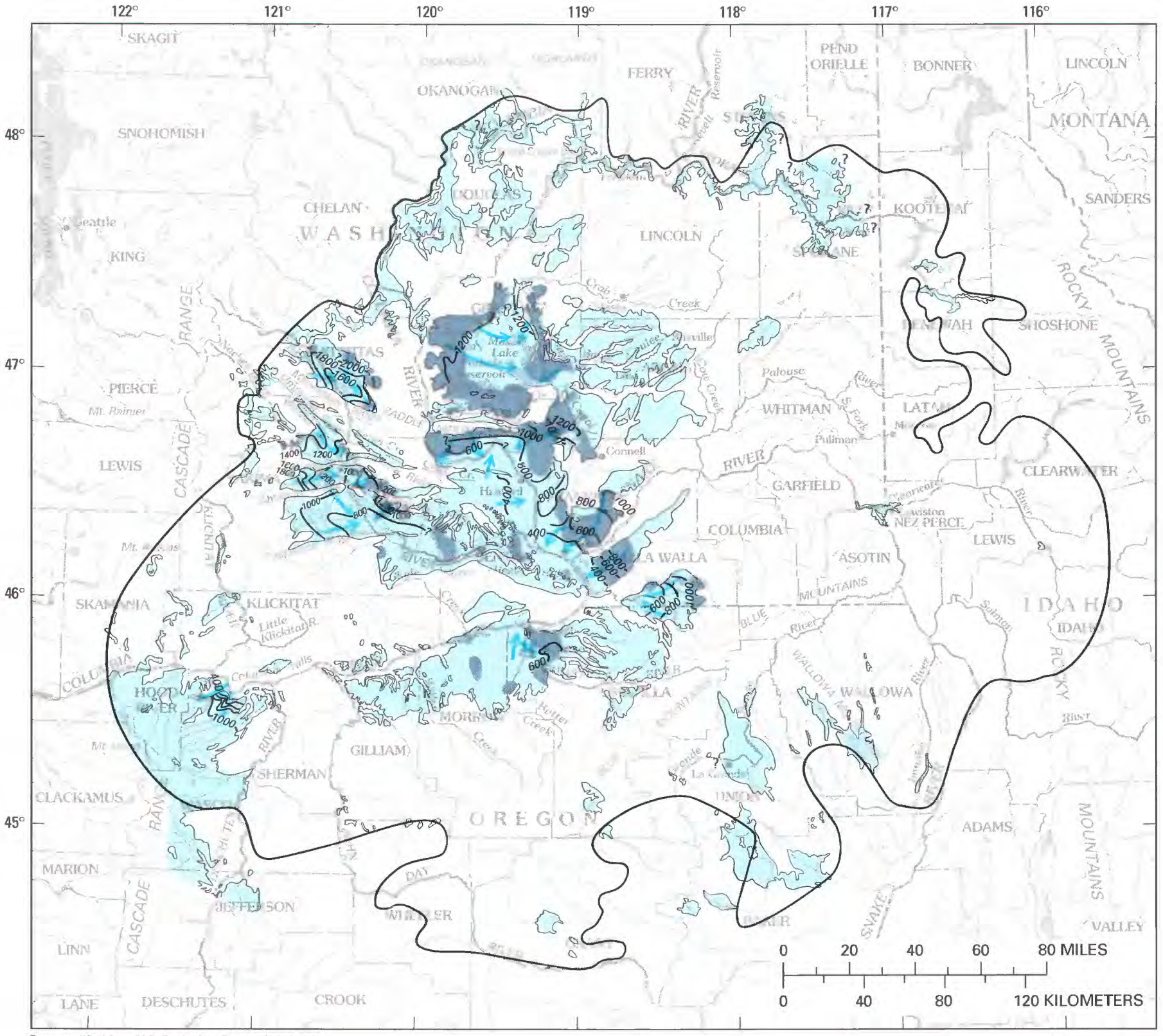

Base modified from U.S. Geological Survey digital data, $1: 2,000,000,1972$

\section{EXPLANATION}

Approximate extent of overburden aquifer-Dashed where approximately located. Queried where unknown

Area saturated due to irrigation

\section{Direction of ground-water flow}

- $400 \rightarrow$ Water-table contour-Shows approximate altitude of water table. Queried where inferred. Contour interval 200 feet. Datum is sea level

\section{_ Boundary of Columbia Plateau aquifer system study area}

FIGLRE 5-Water-table altitude and direction of ground-water flow for the overburden aquifer, representing conditions during spring 1983, for selected areas. (Modified from Bauer and others, 1985). 
was unsaturated prior to the importation of Columbia River water for irrigation. The overburden is saturated now in those areas and stores large quantities of water. The water levels reflect the application and infiltration of surface water and represent a dynamic equilibrium with only small, local declines caused by withdrawal and small rises resulting from increased recharge due to the infiltrating surface water used for irrigation.

Spring 1985 water-level contours and direction of ground-water flow in the three basalt units are shown on figures 6-8. In general, changes of hydraulic head occur with depth at any given location both within and between basalt units. The water-level contours drawn for a unit represent the vertically averaged areal hydraulic head distribution for that unit insofar as the data permitted. The contours are greatly generalized and present a simplified picture of the true, complex three-dimensional flow system.

The potentiometric surface in the Saddle Mountains unit (fig. 6) closely parallels the land surface where there is little or no overburden. Lateral ground-water flow in this basalt unit is generally toward major surface-drainage features, but small and intermediatesized streams also receive base flow from the Saddle Mountains unit. This ground-water flow pattern holds true for the Wanapum and Grande Ronde units (figs. 7 and 8) where they are not overlain by younger basalts or by a great thickness of overburden. In the Palouse subprovince, north of the Snake River, the regional ground-water movement in both the Wanapum and Grande Ronde units closely parallels the southwest regional dip of the basalt. Regional discharge is to the Columbia and Snake Rivers. In the Yakima Fold Belt subprovince, ground water generally moves downward from the anticline axes toward the streams and rivers lying in the intervening synclines. Ground-water movement in the Blue Mountains subprovince is similar, closely paralleling the land surface in areas of high relief and moving downward from the anticline axes to streams and rivers. Ground-water movement in the low-relief areas parallels the dip of the basalt, but varies locally due to geologic structure and ground-water development.

Water levels in the deeply buried parts of the Wanapum and Grande Ronde units are significantly different from those in the overlying units. In the southcentral part of the plateau, water-level contours appear to be less influenced by surface-drainage features, and consequently have a smoother form. An example of this is in the Quincy basin, where ground-water movement in the Wanapum unit (which is at or near the land surface) is toward Moses Lake and Potholes Reservoir (located just south of Moses Lake). Ground-water movement in the underlying Grande Ronde unit, how- ever, is unaffected by these land-surface features, and is to the south toward the Columbia River. Where the regional aquifer system consists mainly, if not completely, of the Grande Ronde unit and it is more than about $500 \mathrm{ft}$ thick, the water-level contours in the lower part of the Grande Ronde unit tend to be smoother and indicate smaller gradients; that is, the lower part of the unit is hydrologically similar to the buried units. This has been noted in Douglas County, Wash., and in the high-relief areas of the Blue Mountains.

In most of the study area, water-table conditions exist in the uppermost basalt flows, whereas water in the deeper basalt is generally semiconfined. Finegrained, tight interbeds and some basalt flow centers are semiconfining beds to the underlying flows. On the basis of water-level data and model analysis, it appears that over most of the plateau the vertical component of flow is downward except near discharge areas; exceptions to this pattern occur near geologic structures and areas with significant ground-water pumpage.

Large water-level gradients (100 to 300 feet per mile) are shown on the flanks of the Blue Mountains, Horse Heaven Hills, Frenchman Hills, Rattlesnake Hills, and Saddle Mountains anticlines (figs. 4, 7 and 8). Waterlevel data from locations on the flanks of anticlines and in other areas where the basalt is steeply dipping show lateral water-level gradients to be approximately equal to or slightly less than the structural gradients.

Since the mid-1960's, pumping ground water for irrigation has disturbed the regional pattern of groundwater flow. For example, in the area of Connell, in Franklin County, Wash., and northward toward the area between Odessa and Lind (fig. 7), a large, upgradient bending or flexure of the contours, typical of lowered water levels, can be seen. A similar upgradient contour flexure attributed to pumping is evident in the Umatilla River basin in Oregon.

The effects of increased recharge because of waterdevelopment practices on the water-level configuration are shown by the downgradient contour flexure just east of Othello (fig. 7), between the 1,000- and 800-foot contours, where the CBIP's large East Low Canal straddles the downgradient flexures.

Seasonal water-level fluctuations in the overburden aquifer and basalt units vary widely because of several factors: (1) annual climatic variations in precipitation and temperature; (2) topographic location as it relates to precipitation variations and geologic conditions; (3) the storage capacity of the rock materials; and (4) irrigation practices. Seasonal water-level changes in the overburden materials are generally less than $10 \mathrm{ft}$, but may be as much as $20 \mathrm{ft}$ in alluvial sediments in the western part of the study area. Hydrographs of U.S. Geological Survey observation wells located in Washington typically 


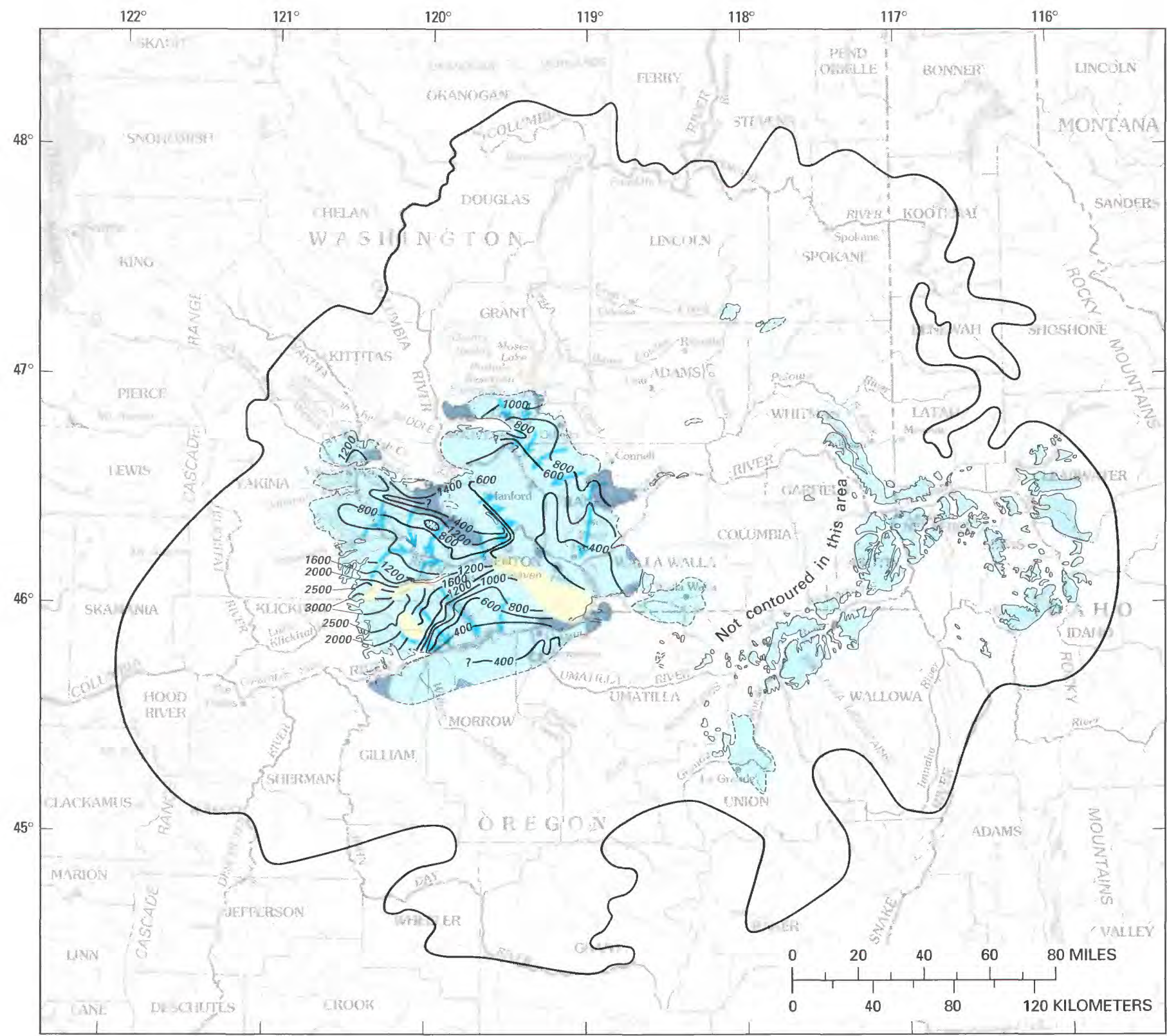

Base modified from U.S. Geological Survey digital data, $1: 2,000,000,1972$

EXPLANATION

Approximate extent of Saddle Mountains unit-Dashed where inferred

Generalized area where unit saturated due to irrigation

Area where unit is unsaturated

$\longleftarrow$ Direction of ground-water flow

-400—? Water-level contour-Shows approximate altitude of water level. Queried where inferred. Contour interval, in feet, is variable. Datum is sea level

\section{Boundary of Columbia Plateau aquifer system study area}

FiguRE 6 - Water-level contours and direction of ground-water flow for the Saddle Mountains unit, spring 1985. (Modified from Lane and Whiteman, 1989). 


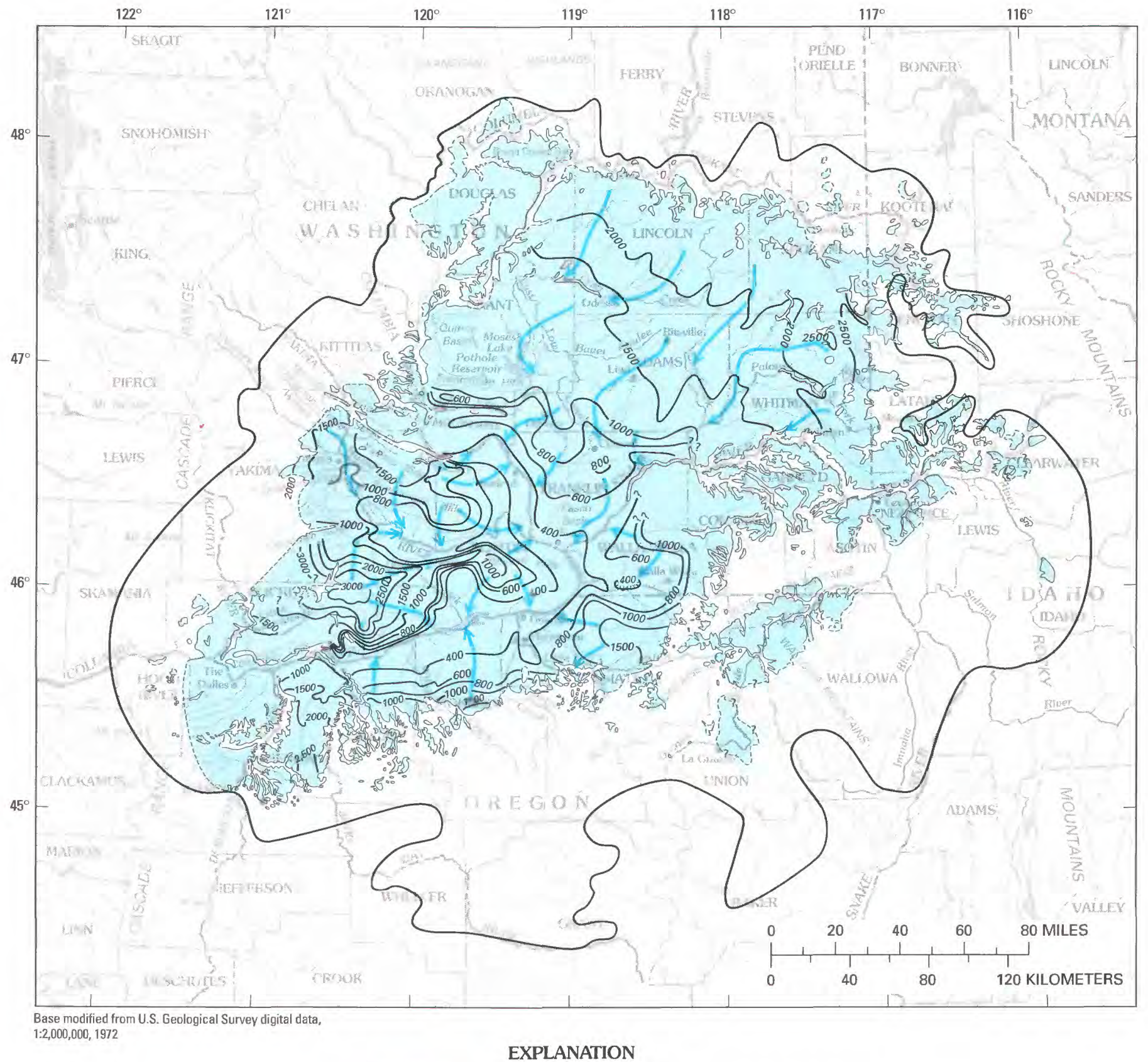

Approximate extent of Wanapum unit-Dashed where approximately located. Queried where inferred

$\longleftarrow$ Direction of ground-water flow

$-800 \rightarrow$ Water-level contour-Shows approximate altitude of water level. Queried where inferred. Contour interval, in feet, is variable. Datum is sea level

\section{Boundary of Columbia Plateau aquifer system study area}

FIGURE 7.-Water-level contours and direction of ground-water flow for the Wanapum unit, spring 1985. (Modified from Lane and Whiteman, 1989). 


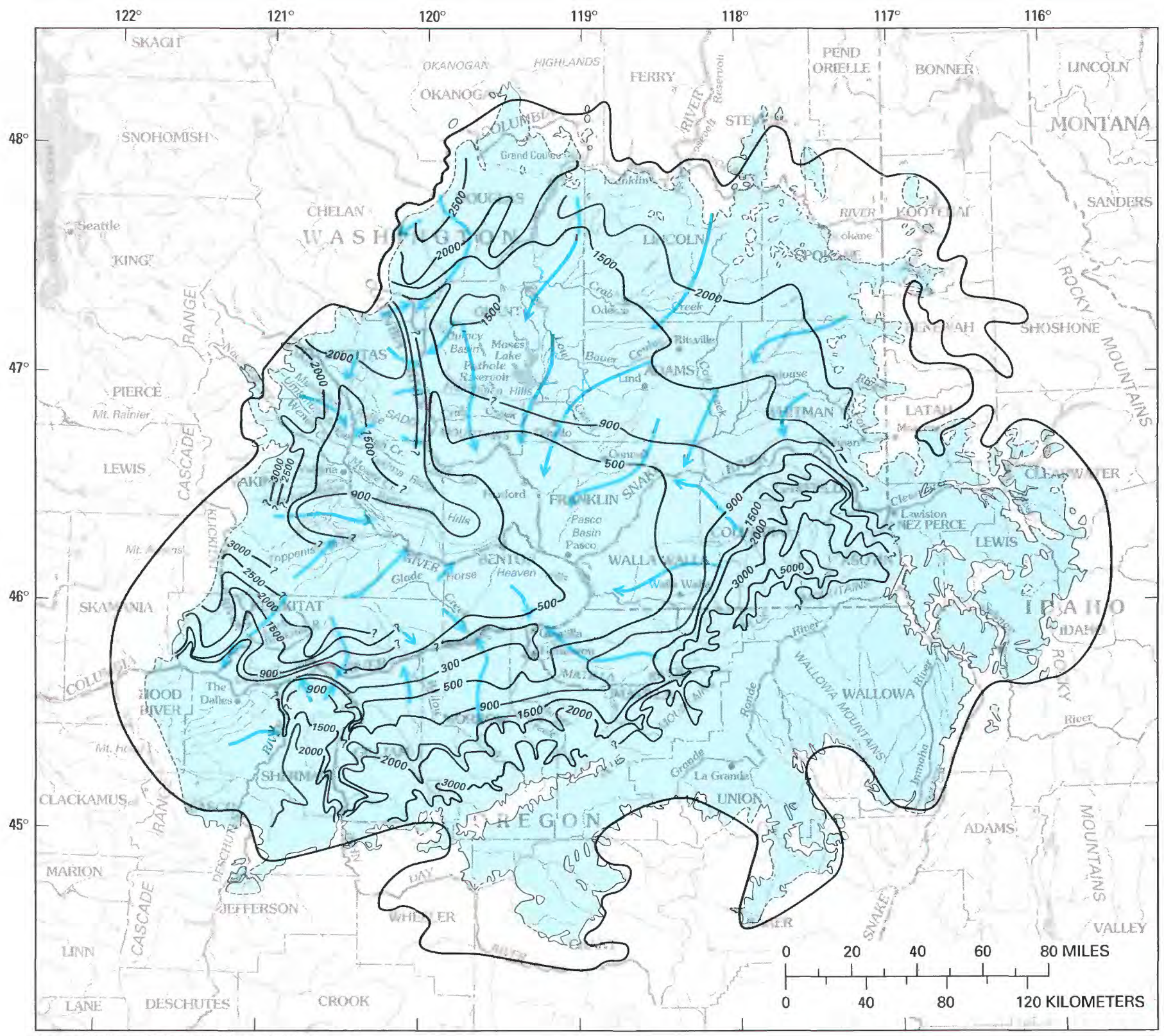

Base modified from U.S. Geological Survey digital data, 1:2,000,000, 1972

EXPLANATION

Approximate extent of Grande Ronde unit-Dashed where approximately located

$\longleftarrow$ Direction of ground-water flow

$-900 \rightarrow$ Water-level contour-Shows approximate altitude of water level. Queried where inferred. Contour interval, in feet, is variable. Datum is sea level

Boundary of Columbia Plateau aquifer system study area

FiguRE 8. - Water-level contours and direction of ground-water flow for the Grande Ronde unit, spring 1985. (Modified from Lane and Whiteman, 1989). 
show water-level fluctuations of less than $10 \mathrm{ft}$ in the shallower basalt units (Cline, 1984; Whiteman and others, 1994).

\section{RECHARGE}

Recharge to the aquifer system is primarily from precipitation and applied irrigation water, and secondarily from surface-water bodies, such as canals, rivers, lakes, and reservoirs. Recharge from precipitation is controlled by both daily and annual climatic variations and is thus highly variable both temporally and spatially. Recharge, as discussed in this report, does not include leakage from rivers, lakes, and reservoirs. These items are considered a separate water-budget component and are discussed in the Regional Ground-Water Flow section.

Recharge was estimated by Bauer and Vaccaro (1990) on a daily basis for 53 basins or zones (fig. 9) by applying a daily energy-soil-water balance model (Bauer and Vaccaro, 1987b). The model computes deep percolation of water for a control volume that includes vegetation, if any, covering the land surface down to the daily maximum prevalent root depth; or, for the case of unvegetated areas, down to the depth of the soil or $5 \mathrm{ft}$, whichever is less (Bauer and Vaccaro, 1987b). The modeled areas were discretized into rectangular cells over which the daily calculations were made. The daily estimates then were used to arrive at a long-term estimate of recharge for both predevelopment and current landuse conditions. The 22-year period of record from 1956 to 1977 was used to estimate recharge for most of the basins or areas, a period that exhibited reasonable climatic variation.

Estimates of recharge and other pertinent information for the 53 zones under predevelopment and current land-use conditions are given in table 3 . The areas included most of the irrigated croplands and most of the area where annual precipitation is less than $11 \mathrm{in} / \mathrm{yr}$. The hydrologic study area (fig. 2) was divided into the same cells used for the ground-water model, $2.5 \mathrm{~min}-$ utes of latitude by 2.0 minutes of longitude (about 2.8 by 1.7 miles). The recharge estimates for each cell in the 53 zones then were aggregated to those ground-water model cells. Recharge was estimated for the cells in the remainder of the hydrologic area through the use of a polynomial regression equation that related the 22-year average annual precipitation to the estimated predevelopment recharge for each of the cells in each modeled area (about 30,000 data values).

The plateau-wide, long-term, time-averaged estimate of recharge for predevelopment land-use conditions is about $6,566 \mathrm{ft}^{3} / \mathrm{s}$, or $2.7 \mathrm{in} / \mathrm{yr}$, and for current (1980's) land-use conditions about 10,205 $\mathrm{ft}^{3} / \mathrm{s}$ (4.24 in/ yr). Thus, recharge has been increased by about 3,639 $\mathrm{ft}^{3} / \mathrm{s}(1.5 \mathrm{in} / \mathrm{yr})$ due to the infiltration of irrigation waters.

The estimates of recharge for current (1980's) landuse conditions are presented in figure 10. The estimates include some small changes in local areas that were derived during the calibration of the ground-water flow model (Hansen and others, 1994). The most apparent fact that can be ascertained from figure 10 is the large range ( 0.0 to more than $50 \mathrm{in} / \mathrm{yr}$ ) and areal variability of the values. The areas of extensive surface-water irrigation can also be easily identified in the central plateau and along the Yakima River.

\section{DISCHARGE}

Discharge from the ground-water system, excluding ground-water pumpage, is mainly to surface-water bodies and springs and seeps along canyon and coulee walls. Lesser quantities of ground water discharge to the atmosphere as evapotranspiration. It is difficult to determine the actual discharge because of the large streamflow quantities, numerous impoundments, and streamflow regulation in the large rivers. Additionally, flow in the many small perennial and ephemeral streams and the diffuse nature of the seepage are not easily measured.

The location and quantity of discharge from the ground-water system was estimated for some smaller surface-water bodies and for ground-water pumpage. Average long-term ground-water discharge to a stream is termed "base flow" and can be quantified by the lowflow characteristics of a stream. Low-flow characteristics vary widely over the study area, and are discussed by Nelson (1991). The discharge to some of the smaller surface-water bodies estimated from the "base flow" accounts for about 26 percent, or $2,600 \mathrm{ft}^{3} / \mathrm{s}$, of the current recharge. This estimated discharge to some of the smaller surface-water bodies was used as a calibration check for the ground-water model. Estimates of discharge as ground-water pumpage (table 4) account for some 11 percent of the current estimate of recharge. The regional distribution and rate of discharge excluding pumpage were estimated using the ground-water model (Hansen and others, 1994), and are presented for current conditions on figure 11 . The ground-water discharge is also presented in tables 5 and 6 , which show the model-calculated regional water budget. Figure 11 and tables 5 and 6 together provide a summary of the estimated ground-water discharge for the Columbia Plateau aquifer system. 


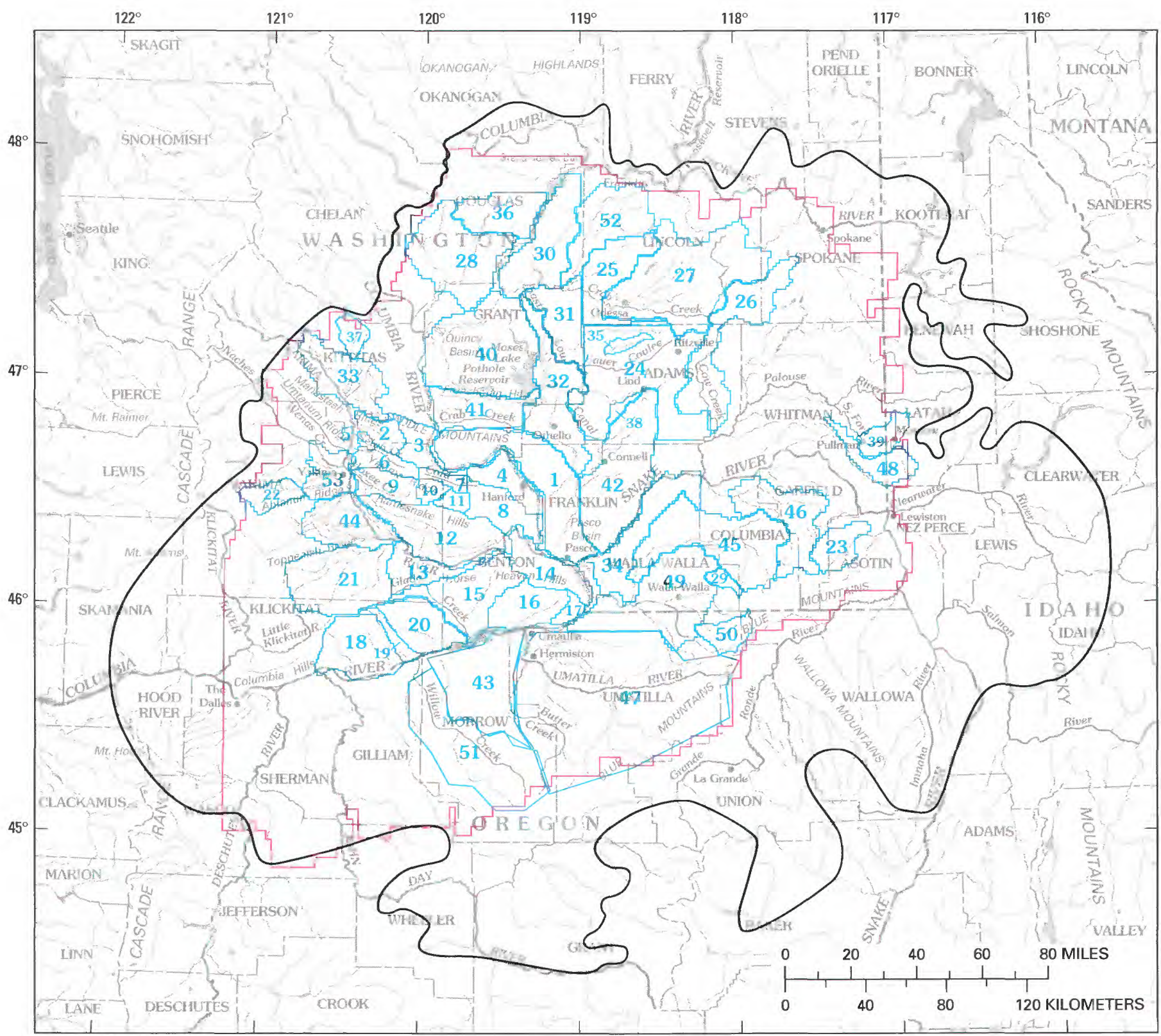

Base modified from U.S. Geological Survey digital data, $1: 2,000,000,1972$

EXPLANATION

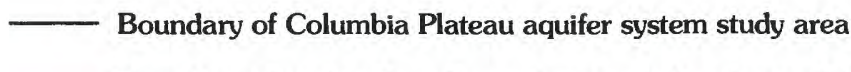

Boundary of regional aquifer system ground-water model

Boundary of recharge simulation zone

14. Recharge simulation zone reference number as given in table 3

FIGURE 9.-Location of the 53 basins, or zones, for which recharge was estimated using a daily deep-percolation model. (From Bauer and Vaccaro, 1990). 
TABLE 3.-Summary of estimated recharge and data used for predevelopment and current land-use conditions, Columbia Plateau aquifer system (from Bauer and Vaccaro, 1990)

\begin{tabular}{|c|c|c|c|c|c|c|c|c|c|}
\hline \multirow{2}{*}{$\begin{array}{l}\text { Zone } \\
\text { reference } \\
\text { number } \\
\text { (see figure 9) }\end{array}$} & \multirow[b]{2}{*}{$\begin{array}{l}\text { Average } \\
\text { precipitation }\end{array}$} & \multirow{2}{*}{$\begin{array}{l}\text { Average } \\
\text { current } \\
\text { irrigation }\end{array}$} & \multirow{2}{*}{$\begin{array}{c}\text { Average } \\
\text { potential } \\
\text { evapotran- } \\
\text { spiration }\end{array}$} & \multicolumn{2}{|c|}{$\begin{array}{c}\text { Average actual } \\
\text { evapotranspiration }\end{array}$} & \multicolumn{2}{|c|}{$\begin{array}{l}\text { Average stream } \\
\text { discharge }\end{array}$} & \multicolumn{2}{|c|}{ Average recharge } \\
\hline & & & & $\begin{array}{l}\text { Predevel- } \\
\text { opment }\end{array}$ & Current & $\begin{array}{l}\text { Surface } \\
\text { runoff }\end{array}$ & $\begin{array}{l}\text { Base } \\
\text { flow }\end{array}$ & $\begin{array}{l}\text { Predevel- } \\
\text { opment }\end{array}$ & Current \\
\hline 1 & 7.29 & 23.74 & 43.06 & 6.74 & 18.56 & $* 0.06$ & 0 & 0.43 & 12.27 \\
\hline 2 & 8.91 & .32 & 35.93 & 7.62 & 7.83 & .10 & 0 & 1.25 & 1.35 \\
\hline 3 & 9.34 & .29 & 39.92 & 7.75 & 7.97 & $* 13$ & 0 & 1.37 & 1.45 \\
\hline 4 & 6.61 & 0 & 42.45 & 6.09 & 6.09 & $* .07$ & 0 & .38 & .38 \\
\hline 5 & 8.77 & 0 & 36.14 & 7.54 & 7.54 & $*_{0}$ & 0 & 1.18 & 1.18 \\
\hline 6 & 8.64 & .67 & 37.32 & 7.66 & 8.07 & .12 & 0 & .66 & .93 \\
\hline 7 & 8.26 & 0 & 39.43 & 6.62 & 6.66 & .19 & 0 & 1.31 & 1.29 \\
\hline 8 & 6.95 & .23 & 41.89 & 6.61 & 6.73 & $*_{0}$ & 0 & .30 & .29 \\
\hline 9 & 7.64 & 6.50 & 38.92 & 7.24 & 12.47 & .10 & 0 & .43 & 1.56 \\
\hline 10 & 7.93 & 0 & 40.25 & 7.39 & 7.47 & $*_{0}$ & 0 & .45 & .41 \\
\hline 11 & 7.76 & 0 & 41.49 & 7.24 & 7.28 & $* 0$ & 0 & .44 & .43 \\
\hline 12 & 7.41 & 22.02 & 41.72 & 7.28 & 22.11 & .07 & 0 & .15 & 7.26 \\
\hline 13 & 8.19 & 9.86 & 42.15 & 7.66 & 15.13 & $* 0$ & 0 & .47 & 2.83 \\
\hline 14 & 7.95 & 7.20 & 42.82 & 7.36 & 11.56 & .14 & 0 & .23 & 2.83 \\
\hline 15 & 6.98 & 2.73 & 40.56 & 6.52 & 9.23 & .16 & .04 & .13 & .66 \\
\hline 16 & 8.31 & 4.30 & 40.56 & 7.71 & 10.68 & $* 16$ & 0 & .39 & 1.78 \\
\hline 17 & 8.09 & 5.31 & 41.19 & 7.39 & 11.54 & $* .40$ & 0 & .26 & 1.50 \\
\hline 18 & 12.05 & .13 & 40.47 & 8.64 & 8.75 & 2.44 & 1.29 & 1.30 & 1.33 \\
\hline 19 & 10.09 & 0 & 40.71 & 8.57 & 8.54 & 1.26 & 1.20 & .83 & .87 \\
\hline 20 & 9.19 & 1.48 & 41.04 & 7.49 & 8.77 & .76 & .06 & .87 & 1.16 \\
\hline 21 & 17.27 & .08 & 36.16 & 9.92 & 10.00 & 3.61 & 3.15 & 5.39 & 5.39 \\
\hline 22 & 22.75 & 1.83 & 28.69 & 10.58 & 11.65 & 3.56 & 5.08 & 10.52 & 11.11 \\
\hline 23 & 22.32 & 0 & 36.13 & 14.05 & 14.05 & 2.82 & 3.55 & 6.01 & 6.00 \\
\hline 24 & 6.94 & 2.51 & 44.24 & 9.19 & 11.64 & .13 & 0 & .57 & .51 \\
\hline 25 & 10.33 & 1.54 & 43.43 & 8.92 & 10.68 & $* 0$ & 0 & 1.36 & 1.20 \\
\hline 26 & 12.61 & .77 & 41.32 & 10.24 & 11.13 & .29 & .32 & 2.30 & 2.11 \\
\hline 27 & 12.54 & .27 & 41.32 & 10.24 & 10.90 & .65 & .25 & 1.68 & 1.35 \\
\hline 28 & 10.05 & .11 & 39.09 & 8.75 & 9.10 & .07 & 0 & 1.16 & 1.01 \\
\hline 29 & 21.80 & 0 & 37.45 & 14.37 & 14.94 & 4.30 & 1.70 & 3.51 & 2.97 \\
\hline 30 & 10.09 & 1.62 & 41.64 & 8.41 & 9.71 & $* 22$ & 0 & 1.42 & 1.81 \\
\hline 31 & 8.69 & 3.92 & 42.49 & 7.91 & 10.81 & ${ }^{*} 0$ & 0 & .73 & 1.79 \\
\hline 32 & 7.78 & 30.15 & 41.41 & 7.11 & 19.08 & $* .05$ & 0 & .58 & 18.71 \\
\hline 33 & 11.12 & 17.43 & 34.73 & 8.33 & 18.71 & ${ }^{*} 0$ & 0 & 2.74 & 9.72 \\
\hline 34 & 10.24 & 3.59 & 43.09 & 8.89 & 12.01 & $* 25$ & 0 & 1.04 & 1.58 \\
\hline 35 & 8.94 & 3.96 & 44.78 & 8.23 & 10.68 & .28 & 0 & .24 & 1.86 \\
\hline 36 & 10.26 & 0 & 40.00 & 8.93 & 9.32 & $* .11$ & 0 & 1.17 & .85 \\
\hline 37 & 24.30 & 0 & 27.92 & 11.71 & 11.71 & 3.32 & 9.24 & 10.65 & 10.65 \\
\hline 38 & 8.24 & 6.82 & 44.9 & 8.06 & 13.89 & .10 & 0 & .13 & 1.21 \\
\hline 39 & 22.42 & 0 & 34.5 & 16.03 & 16.54 & 2.39 & 2.28 & 4.13 & 2.79 \\
\hline 40 & 8.15 & 18.64 & 40.41 & 7.32 & 16.30 & $* .21$ & 0 & .57 & 10.07 \\
\hline 41 & 8.04 & 21.02 & 41.71 & 7.13 & 17.10 & ${ }^{*} 0.04$ & 0 & 0.82 & 11.89 \\
\hline 42 & 9.12 & 1.99 & 44.55 & 8.14 & 9.76 & ${ }^{*} .07$ & 0 & 0.84 & 1.30 \\
\hline 43 & 9.04 & 1.97 & 42.47 & 9.04 & 11.02 & ${ }^{*} 0$ & 0 & .01 & .01 \\
\hline 44 & 8.61 & 26.68 & 39.91 & 8.09 & 25.10 & $* 0$ & 0 & .44 & 10.33 \\
\hline 45 & 18.28 & .37 & 38.75 & 12.33 & 13.18 & 3.16 & 1.54 & 3.30 & 2.93 \\
\hline 46 & 21.06 & 0 & 38.51 & 12.64 & 12.98 & 2.11 & 4.06 & 6.79 & 6.50 \\
\hline 47 & 16.49 & .84 & 42.98 & 12.89 & 13.91 & 2.40 & 1.86 & 1.53 & 1.55 \\
\hline 48 & 20.96 & 0 & 36.21 & 15.59 & 14.84 & 2.57 & 0 & 2.98 & 3.65 \\
\hline 49 & 12.93 & 5.20 & 40.13 & 11.45 & 14.53 & $* 02$ & 0 & 1.45 & 3.33 \\
\hline 50 & 37.65 & .28 & 35.72 & 15.08 & 15.53 & 10.05 & 24.47 & 15.06 & 15.19 \\
\hline 51 & 11.35 & .66 & 41.21 & 11.15 & 11.81 & ${ }^{*} 0$ & 0 & .29 & .29 \\
\hline 52 & 11.34 & .15 & 41.85 & 10.01 & 9.58 & .46 & 0 & .90 & 1.63 \\
\hline 53 & 8.93 & 23.84 & 37.60 & 8.03 & 20.73 & ${ }^{*} 0$ & 0 & 0.84 & 11.15 \\
\hline
\end{tabular}

* Stream runoff assumed to be zero from all land surfaces within the area; however, the presence of surface-water bodies results in surface-runoff output for those areas during model simulations. 


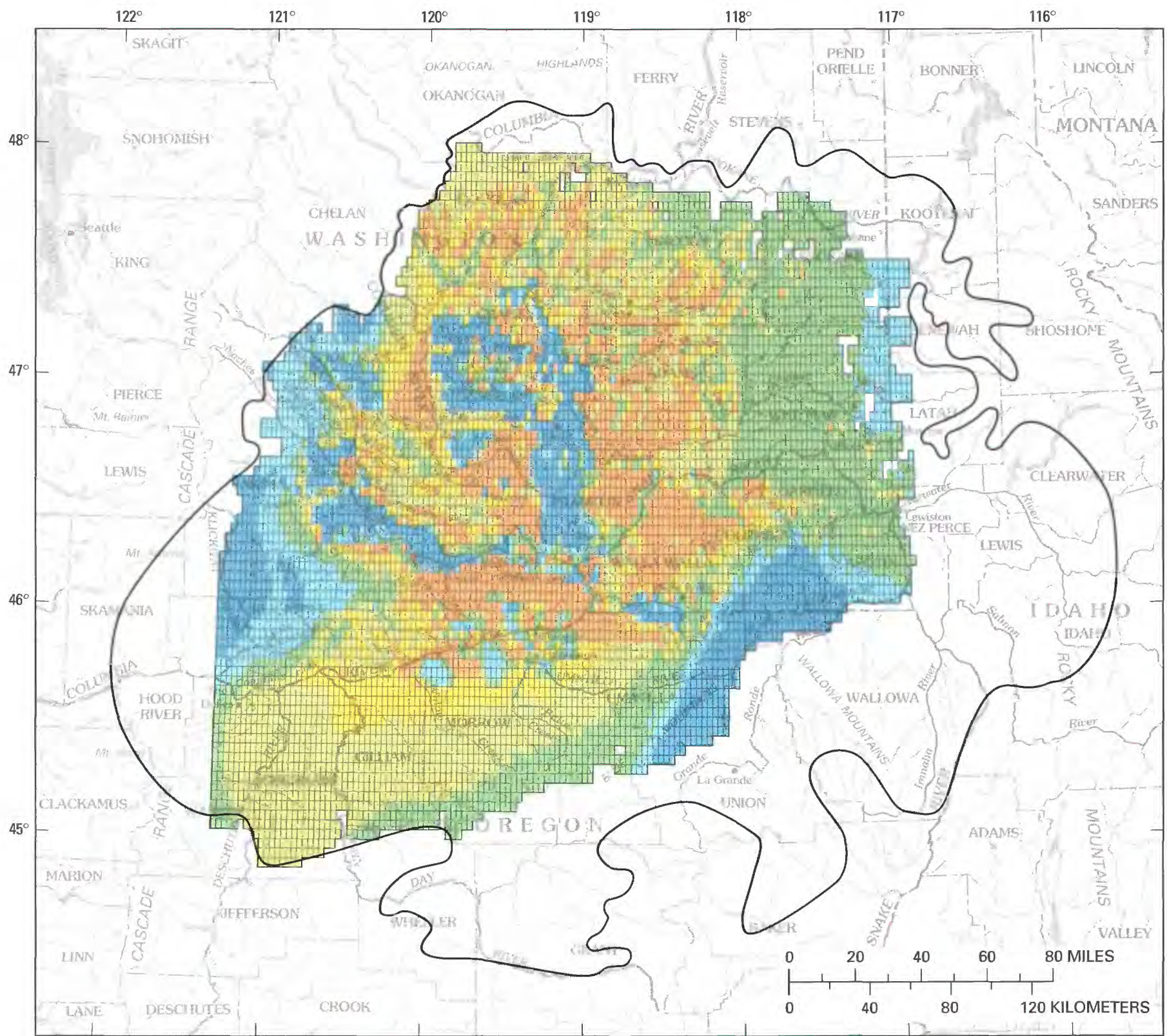

Base modified from U.S. Geological Survey digital data $1: 2,000,000,1972$

\section{EXPLANATION}

Recharge, in inches per year

$0.02-0.5$

$0.5-1.0$

$1.0-2.0$

$2.0-5.0$

$5.0-10.0$

$10.0-52.2$

\section{Model grid}

Boundary of model

Boundary of Columbia Plateau aquifer system study area

FIGURE 10.-Distribution of estimated recharge for current (1980's) land-use conditions. 
TABLE 4.-Ground-water pumpage by study unit from the Columbia Plateau, Washington, Oregon, and Idaho, 1945 to 1984 (from Cline and Collins, 1992) [Values in acre-feet per year]

\begin{tabular}{|c|c|c|c|c|c|}
\hline Water-yielding unit & Washington & Oregon & Water-yielding unit & Washington & Oregon \\
\hline 1945 & & & 1973 & & \\
\hline Grande Ronde & 9,040 & 450 & Grande Ronde & 106,080 & 36,530 \\
\hline Wanapum & 13,270 & 4,200 & Wanapum & 184,130 & 32,600 \\
\hline Saddle Mountains & 1,970 & 810 & Saddle Mountains & 11,900 & 2,870 \\
\hline Overburden & 23,490 & 2,460 & Overburden & 108,300 & 28,070 \\
\hline TOTAL & 47,770 & 7,920 & TOTAL & 410,410 & 100,070 \\
\hline 1950 & & & 1975 & & \\
\hline Grande Ronde & 14,650 & 1,440 & Grande Ronde & 149,920 & 44,270 \\
\hline Wanapum & 26,160 & 8,330 & Wanapum & 200,830 & 38,200 \\
\hline Saddle Mountains & 3,390 & 570 & Saddle Mountains & 12,320 & 3,550 \\
\hline Overburden & 38,830 & 4,000 & Overburden & 137,580 & 30,960 \\
\hline TOTAL & 83,039 & 14,340 & TOTAL & 500,650 & 117,580 \\
\hline 1955 & & & 1977 & & \\
\hline Grande Ronde & 22,280 & 4,990 & Grande Ronde & 213,230 & 58,780 \\
\hline Wanapum & 41,850 & 12,030 & Wanapum & 265,130 & 44,680 \\
\hline Saddle Mountains & 4,010 & 960 & Saddle Mountains & 18,580 & 4,030 \\
\hline Overburden & 46,900 & 6,760 & Overburden & 189,610 & 30,930 \\
\hline TOTAL & 115,040 & 24,740 & TOTAL & $\overline{686,550}$ & 138,420 \\
\hline 1960 & & & 1979 & & \\
\hline Grande Ronde & 31,630 & 11,850 & Grande Ronde & 248,350 & 62,820 \\
\hline Wanapum & 51,820 & 19,400 & Wanapum & 320,960 & 57,010 \\
\hline Saddle Mountains & 4,890 & 1,890 & Saddle Mountains & 21,710 & 4,250 \\
\hline Overburden & 48,210 & 8,280 & Overburden & 191,640 & 33,030 \\
\hline TOTAL & 136,550 & 41,420 & TOTAL & 782,660 & 157,110 \\
\hline 1965 & & & 1982 & & \\
\hline Grande Ronde & 49,890 & 14,960 & Grande Ronde & 239,330 & 60,490 \\
\hline Wanapum & 80,070 & 22,300 & Wanapum & 297,680 & 58,110 \\
\hline Saddle Mountains & 5,980 & 2,180 & Saddle Mountains & 23,590 & 4,260 \\
\hline Overburden & 53,100 & 11,600 & Overburden & 190,930 & 32,380 \\
\hline TOTAL & 189,040 & 51,040 & TOTAL & 751,530 & 155,240 \\
\hline 1968 & & & 1983 & & \\
\hline Grande Ronde & 80,200 & 22,660 & Grande Ronde & 192,800 & 55,930 \\
\hline Wanapum & 131,390 & 27,030 & Wanapum & 268,960 & 54,980 \\
\hline Saddle Mountains & 9,090 & 2,480 & Saddle Mountains & 23,130 & 4,780 \\
\hline Overburden & 62,190 & 15,690 & Overburden & 181,150 & 31,570 \\
\hline TOTAL & 283,070 & 67,860 & TOTAL & $\overline{666,040}$ & 147,260 \\
\hline 1970 & & & 1984 & & \\
\hline Grande Ronde & 87,910 & 31,400 & Grande Ronde & 205,390 & 55,800 \\
\hline Wanapum & 141,530 & 30,800 & Wanapum & 271,480 & 54,990 \\
\hline Saddle Mountains & 11,160 & 2,690 & Saddle Mountains & 23,720 & 4,670 \\
\hline Overburden & 75,420 & 22,980 & Overburden & & \\
\hline TOTAL & 316,020 & 87,870 & TOTAL & 680,930 & 147,340 \\
\hline
\end{tabular}




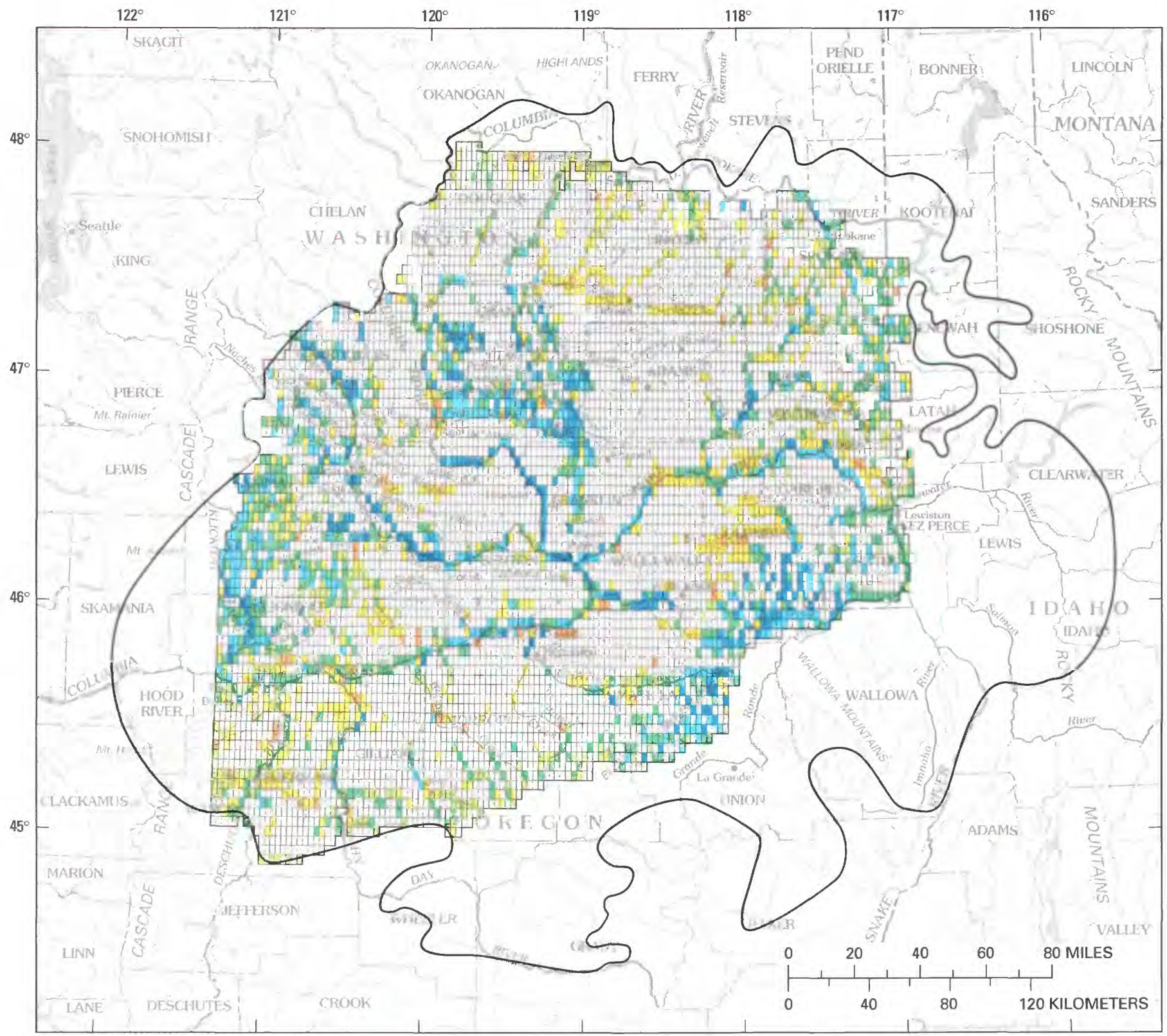

Base modified from U.S. Geological Survey digital data, EXPLANATION

Discharge, in inches per year

$0.0-0.1$

$0.1-1.0$

$1.0-2.0$

$2.0-5.0$

$5.0-10.0$

$10.0-109.2$

Model grid

Boundary of model

Boundary of Columbia Plateau aquifer system study area

FigURE 11.-Distribution of estimated discharge for current (1980's) land-use conditions. 


\begin{tabular}{lrrr}
$\begin{array}{c}\text { TABLE 5. Calculated water budget for the predevelopment and time- } \\
\text { averaged simulations for the Columbia Plateau aquifer system } \\
\text { (from Hansen and others, 1994, in preparation) } \\
\text { [Values in cubic feet per second] }\end{array}$ \\
$\begin{array}{lrrrr}\text { Predevel- } \\
\text { opment } \\
\text { simulation } \\
\text { (P) }\end{array}$ & $\begin{array}{c}\text { Time- } \\
\text { averaged } \\
\text { simulation } \\
\text { (TA) }\end{array}$ & $\begin{array}{r}\text { Difference } \\
\text { (TA-P) }\end{array}$ \\
$\begin{array}{lrrrr}\text { Water-budget } \\
\text { component }\end{array}$ & $6,566.5$ & $10,205.0$ & $3,638.5$ \\
\hline Recharge & 553.6 & 556.7 & 3.1 \\
Leakage from rivers & 0.0 & 186.6 & 186.6 \\
Change in storage & $7,120.1$ & $10,948.3$ & $3,828.2$ \\
TOTAL IN & $2,753.9$ & $3,804.5$ & $1,050.6$ \\
$\begin{array}{l}\text { Leakage to rivers } \\
\text { Leakage to drains }\end{array}$ & $3,944.8$ & $5,595.5$ & $1,650.7$ \\
Leakage to seepage faces & 425.5 & 422.6 & -2.9 \\
Pumpage & 0.0 & $1,134.7$ & $1,134.7$ \\
TOTAL OUT & $7,124.2$ & $10,957.3$ & $3,833.1$ \\
\hline
\end{tabular}

TABLE 6.-Calculated water budget for the predevelopment and time-averaged simulations for layers in the ground-water model of the Columbia Plateau aquifer system

[Values in cubic feet per second]

\begin{tabular}{|c|c|c|c|c|c|c|c|c|c|c|}
\hline \multirow[t]{2}{*}{ Water-budget component } & \multicolumn{5}{|c|}{$\begin{array}{c}\text { Predevelopment simulation } \\
\text { Layer }^{1}\end{array}$} & \multicolumn{5}{|c|}{$\begin{array}{l}\text { Time-averaged simulation } \\
\text { Layer }^{1}\end{array}$} \\
\hline & 1 & 2 & 3 & 4 & 5 & 1 & 2 & 3 & 4 & 5 \\
\hline Recharge & 119.3 & 132.6 & $2,184.7$ & $4,131.1$ & 0.0 & $3,202.4$ & 576.7 & $2,267.8$ & $4,160.6$ & 0.0 \\
\hline Leakage from rivers & 452.3 & 11.5 & 45.0 & 44.8 & 0.0 & 407.0 & 8.7 & 69.5 & 71.5 & 0.0 \\
\hline Leakage from overlying layers & 0.0 & 25.9 & 137.1 & 730.7 & 421.4 & 0.0 & 224.6 & 574.6 & 936.4 & 423.1 \\
\hline Leakage from underlying layers & 578.2 & 503.0 & 708.1 & 423.0 & 0.0 & 733.8 & 560.9 & 685.4 & 425.8 & 0.0 \\
\hline Change in storage & 0.0 & 0.0 & 0.0 & 0.0 & 0.0 & 0.0 & 11.7 & 111.8 & 63.1 & 0.0 \\
\hline TOTAL IN & $1,149.8$ & 673.0 & $3,074.9$ & $\overline{5,329.6}$ & 421.4 & $4,343.2$ & $1,382.6$ & $3,709.1$ & $5,657.4$ & 423.1 \\
\hline Leakage to rivers & 912.2 & 180.3 & 522.4 & $1,139.0$ & 0.0 & $1,882.5$ & 274.9 & 531.4 & $1,115.8$ & 0.0 \\
\hline Leakage to drains & 148.4 & 29.9 & 877.5 & $2,889.1$ & 0.0 & $1,670.1$ & 225.2 & 812.3 & $2,888.5$ & 0.0 \\
\hline Leakage to seepage faces & 13.9 & 1.6 & 329.0 & 80.9 & 0.0 & 16.2 & 14.4 & 312.2 & 79.8 & 0.0 \\
\hline Leakage to overlying layers & 0.0 & 369.1 & 620.2 & 800.0 & 423.0 & 0.0 & 503.9 & 685.6 & 790.5 & 425.8 \\
\hline Leakage to underlying layers & 81.5 & 88.5 & 723.6 & 421.4 & 0.0 & 499.9 & 320.8 & 914.9 & 423.1 & 0.0 \\
\hline Pumpage & 0.0 & 0.0 & 0.0 & 0.0 & 0.0 & 285.1 & 39.7 & 449.2 & 360.8 & 0.0 \\
\hline TOTAL OUT & $\overline{1,156.0}$ & $\overline{669.4}$ & $\overline{3,072.7}$ & $\overline{5,330.4}$ & 423.0 & $\overline{4,353.8}$ & $\overline{1,378.9}$ & $\overline{3,705.6}$ & $\overline{5.658 .5}$ & 425.8 \\
\hline
\end{tabular}

${ }^{1}$ Layer 1, overburden aquifer; Layer 2, Saddle Mountains unit and confining unit; Layer 3, Wanapum unit and confining unit; Layer 4, upper Grande Ronde unit; Layer 5, lower Grande Ronde unit 


\section{GROUND-WATER DEVELOPMENT}

Ground-water pumpage on the Columbia Plateau was minimal during the early part of this century, increased moderately after World War II, and then increased rapidly from about 1965 to 1979 (table 4). Since 1979, pumpage has decreased somewhat, owing in part to higher electrical costs for pumping the water and lower prices for crops. Pumpage of ground water from the Columbia Plateau is estimated to have been 56,000 acre-ft in $1945,178,000$ acre-ft in 1960 , and to have increased to a peak of about 940,000 acre-ft by 1979 (table 4; data from Cline and Collins, 1992). By 1983, pumpage had dropped to about 813,000 acre-ft.

Estimates of ground-water pumpage for 1984 have been made for this study by Collins (1987) for the Oregon part of the Columbia Plateau, and by Cline and Knadle (1990) for the Washington part and a small part of Idaho (fig. 12). About 828,270 acre-ft of ground water was pumped from the regional aquifer system in 1984 from an estimated 3,500 high-capacity wells. Between 85 and 90 percent was used for irrigation of nearly onehalf million acres of cropland, and the remainder was used for public supply and industry. The relatively small quantity of ground water used for domestic purposes and other uses, such as stock watering, was not estimated in this analysis.

Of the total 1984 ground-water pumpage (fig. 12) from the regional aquifer system, about 32 percent was from the Grande Ronde unit, 39 percent from the Wanapum unit, 3 percent from the Saddle Mountains unit, and 26 percent from the overburden aquifer. The greatest concentrations of pumpage are near Hermiston, Oreg., and in three centers in Washington--the Odessa-Lind pumping center, the Quincy basin, and southern Franklin County (see fig. 1 for locations).

\section{REGIONAL GROUND-WATER FLOW}

The regional ground-water flow system is described on the basis of results from a three-dimensional finitedifference model of ground-water flow. The model of the Columbia Plateau aquifer system was constructed (Hansen and others, 1994; Bauer and Hansen, in press) in order to obtain a better understanding of the groundwater flow system and the regional hydrology, and to provide the analytical capabilities necessary to assess ground-water management alternatives. The model of McDonald and Harbaugh (1988) as modified by Hansen (1993) was used to solve the ground-water flow equations.

\section{REGIONAL FLOW MODEL}

The hydraulic characteristics (model parameters) were estimated initially for the steady-state predevelopment conditions. The model then was calibrated to time-averaged conditions for current land use. These current conditions represent the average hydrologic conditions for the period from spring 1983 to spring 1985 and approximate a steady-state condition. For the time-averaged simulations, the time-dependent term in the ground-water flow equation becomes a change-instorage term and is added to recharge term. This results from integrating the equation with respect to time over some time interval and, thus, the time-dependent term becomes equal to the average head change for a model cell over the averaging period divided by the time interval and multiplied by the estimated storage coefficient. The model parameters derived from the calibrated time-averaged model then were used in the steady-state model to calculate a predevelopment water-level configuration, areal distribution of ground-water discharge, and a regional water budget for the aquifer system. The calculated predevelopment and time-averaged water levels and water budget were compared to obtain an understanding of the effects of historic waterdevelopment practices. The time-averaged model then was used to assess some simple management strategies. The calibration and use of the regional flow model provided insight and increased understanding of the regional hydrology.

The model grid system used for these analyses consisted of five layers (fig. 3B) and 17,374 active cells (624 for the overburden aquifer and 16,750 for the basalt units) for the predevelopment model, and 17,899 active cells (969 for the overburden aquifer and 16,930 for the basalt units) for the time-averaged model. The average cell dimensions were about $1.5 \mathrm{mi}$ east to west and 2.8 $\mathrm{mi}$ north to south. More cells were needed for the timeaveraged model because 525 previously unsaturated cells became saturated as a result of the delivery, application, and infiltration of surface water used for irrigation during the years of development (Hansen and others, 1994).

The regional ground-water flow system is highly complex because of the geometry of the aquifer system, variability in recharge, geologic structure, presence and location of major and minor stream courses, configuration of individual basalt flows, diagenetic processes, sediment deposition, and tectonic activity. Lateral hydraulic conductivity varies locally and varies as much as five orders of magnitude regionally; the average value for the basalts is about four orders of magnitude larger than the upper limit for rock materials that are considered 'tight' (Neuzil, 1986). Model-derived ver- 


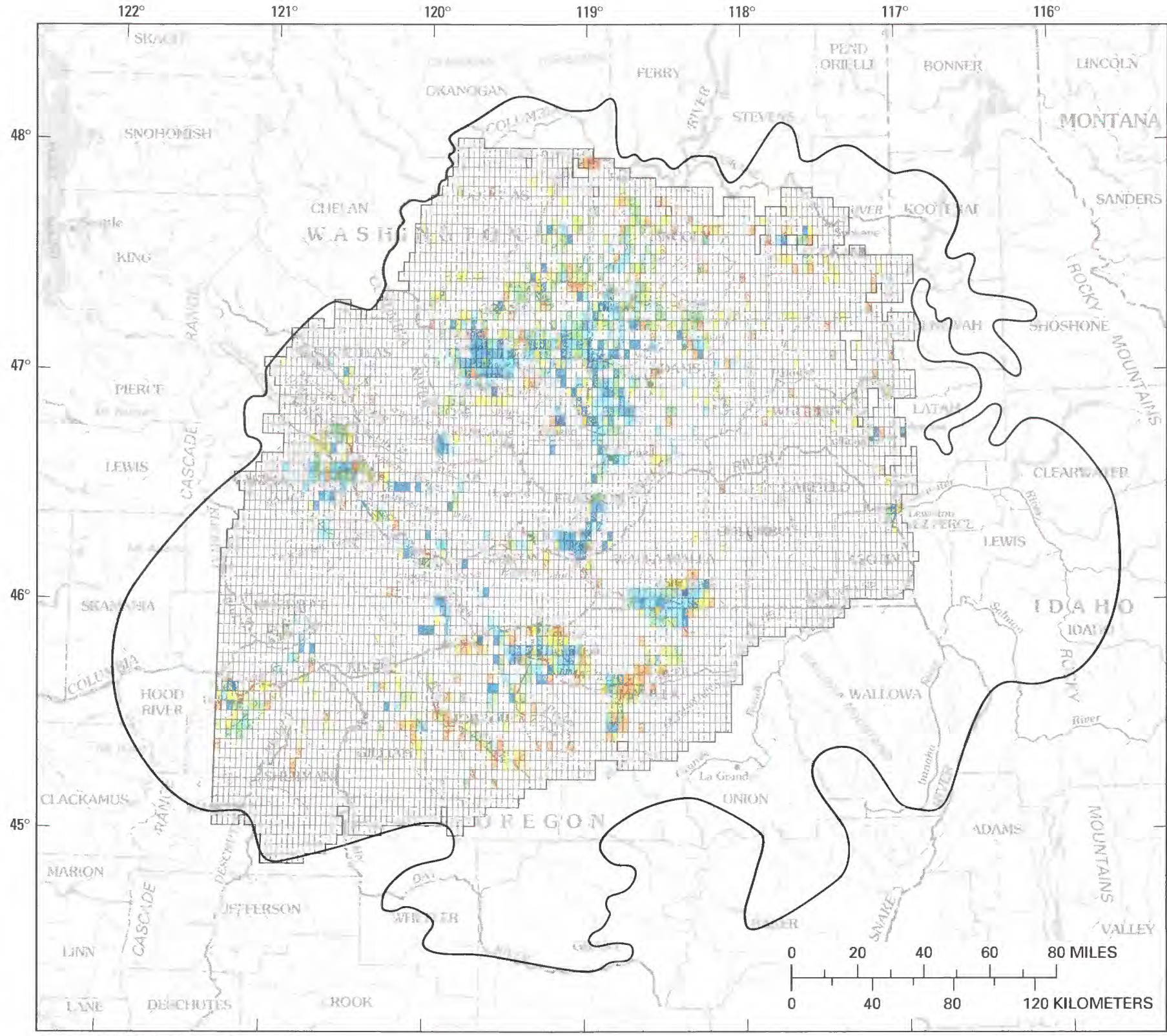

Base modified from U.S. Geological Survey digital data 1:2,000,000, 1972

\section{EXPLANATION}

Pumpage, in inches per year

Less than 0.1

$0.1-0.2$

$0.2-0.5$

$0.5-1.0$

$1.0-2.0$

$2.0-18.0$

Model grid

Boundary of model

Boundary of Columbia Plateau aquifer system study area

FIGURE 12.-Ground-water pumpage from the Columbia Plateau aquifer system, 1984. 
tical hydraulic conductance varies up to eight orders of magnitude regionally and appears to average about $10^{-}$ $11 \mathrm{1} / \mathrm{s}$. Estimates of effective vertical hydraulic conductivity average about $10^{-6} \mathrm{ft} / \mathrm{s}$ and range from about $10^{-}$ 10 to $10^{-2} \mathrm{ft} / \mathrm{s}$.

Calculated ground-water velocities range from $10^{-4}$ to about $20 \mathrm{ft} / \mathrm{d}$ and generally decrease with depth within the aquifer system. Median estimated velocities for the five model layers are, from youngest to oldest, 2 $\mathrm{ft} / \mathrm{d}, 0.2 \mathrm{ft} / \mathrm{d}, 0.4 \mathrm{ft} / \mathrm{d}, 0.2 \mathrm{ft} / \mathrm{d}$, and $0.1 \mathrm{ft} / \mathrm{d}$ (Hansen and others, 1994). The median velocities indicate that ground-water residence time for short flow paths (less than $10 \mathrm{mi}$ ) are on the order of a few months to 250 years; for intermediate flow paths (10 to $30 \mathrm{mi}), 250$ to 500 years; and for long flow paths (more than $30 \mathrm{mi}$ ) the residence time is 500 to more than 5,000 years. The long flow paths and slow ground-water movement in the deep basalts allow for the geochemical evolution of the flowing ground waters and precipitation of secondary minerals; this, in turn, affects the hydraulic characteristics of the basalts and, subsequently, the rate and quantity of ground-water movement.

\section{PREDEVELOPMENT LAND-USE CONDITIONS}

The model-calculated water budget for predevelopment land-use conditions (tables 5 and 6 and fig. 13) shows that, of the estimated $33,000 \mathrm{ft}^{3} / \mathrm{s}$ of precipitation that fell within the ground-water model boundaries, about $6,566 \mathrm{ft}^{3} / \mathrm{s}$, or 20 percent $(2.72 \mathrm{in} / \mathrm{yr})$, became ground-water recharge. About $119 \mathrm{ft}^{3} / \mathrm{s}(0.55 \mathrm{in} / \mathrm{yr})$ entered the overburden aquifer, $133 \mathrm{ft}^{3} / \mathrm{s}(0.58 \mathrm{in} / \mathrm{yr})$ entered the Saddle Mountains unit, 2,185 $\mathrm{ft}^{3} / \mathrm{s}(2.0$ in/ yr) entered the Wanapum unit, and $4,131 \mathrm{ft}^{3} / \mathrm{s}(4.7 \mathrm{in} /$ yr) entered the upper Grande Ronde. Much of the recharge followed short flow paths within local flow systems and discharged as baseflow to small streams and as seeps and springs along canyon and coulee walls.

Of the $1,074 \mathrm{ft}^{3} / \mathrm{s}$ that discharged from the overburden aquifer, about 50 percent was water from underlying basalt units. About $71 \mathrm{ft}^{3} / \mathrm{s}$ of the discharge from the Saddle Mountains unit was water received from the overburden aquifer and the underlying Wanapum unit. About $840 \mathrm{ft}^{3} / \mathrm{s}$ of the water that discharged from the Wanapum unit was ground water received from other units and about $1,154 \mathrm{ft}^{3} / \mathrm{s}$ of the upper Grande Ronde discharge was water that had moved through other units.

Before water-development practices began, the saturated part of the overburden aquifer covered about $2,910 \mathrm{mi}^{2}$ (volume of about $140 \mathrm{mi}^{3}$ ). The saturated deposits were located in structural basins along river and stream courses. In these areas, typified by low precipitation, this unit received about $119 \mathrm{ft}^{3} / \mathrm{s}(0.56 \mathrm{in} / \mathrm{yr})$ of recharge or less than 2 percent of the aquifer system's recharge. However, the unit was active hydrologically because it overlies regional and subregional discharge areas. Thus, about 15 percent of the ground water discharged through the overburden aquifer. Ground-water movement was from the uplands to lowlands in the basins and subsequently to rivers and streams, the altitude of which is the major control on the ground-water movement.

The predevelopment saturated part of the Saddle Mountains unit covered about $4,910 \mathrm{mi}^{2}$ (volume of about $340 \mathrm{mi}^{3}$ ), of which about $3,040 \mathrm{mi}^{2}$ cropped out. The unit received about $133 \mathrm{ft}^{3} / \mathrm{s}(0.59 \mathrm{in} / \mathrm{yr})$ of recharge where it cropped out. Movement of ground water in this unit is controlled primarily by topography and geologic structure, and secondarily by the heads in the overburden aquifer (which overlies about 38 percent of the unit) and the altitude of the Columbia and Yakima Rivers.

The Wanapum unit covers about $20,540 \mathrm{mi}^{2}$ (volume of about $1,700 \mathrm{mi}^{3}$ ), representing about 63 percent of the area within the modeled region, and about $14,750 \mathrm{mi}^{2}$ of the unit crops out. This outcrop area received an estimated direct recharge from precipitation of $2,185 \mathrm{ft}^{3} / \mathrm{s}$ $(2.0 \mathrm{in} / \mathrm{yr})$, only about 24 percent of which reached the regional discharge area located along the Columbia and Snake Rivers. The remaining water in the unit discharged along short to intermediate flow paths and to the other units. Topography, geologic structure, and surface-water features control the movement of water within this unit. In the western part of the Palouse subprovince, individual basalt flows in the Wanapum unit appear to be laterally continuous and have small vertical hydraulic conductivity. Throughout much of the remainder of the area, the unit appears to be hydraulically well-connected to overlying units and has a highly variable connection to the underlying upper Grande Ronde. The lateral hydraulic conductivity is small in the high-relief areas of the Yakima Fold Belt and in other structurally complex areas, and is large throughout much of the remainder of the unit's extent.

Flow paths within the Wanapum unit are short and terminate at surface-water features within the Blue Mountains subprovince. In the Yakima Fold Belt, flow paths originate in topographic highs, generally anticlines where lateral hydraulic head gradients are large $(100-200 \mathrm{ft} / \mathrm{mi})$, and terminate along major rivers in the intervening synclinal valleys where hydraulic gradients are low $(10-20 \mathrm{ft} / \mathrm{mi})$.

The upper Grande Ronde covers about $32,500 \mathrm{mi}^{2}$, or all but about $190 \mathrm{mi}^{2}$ of the modeled area; the unit is absent in the periphery of the northeastern part of the 


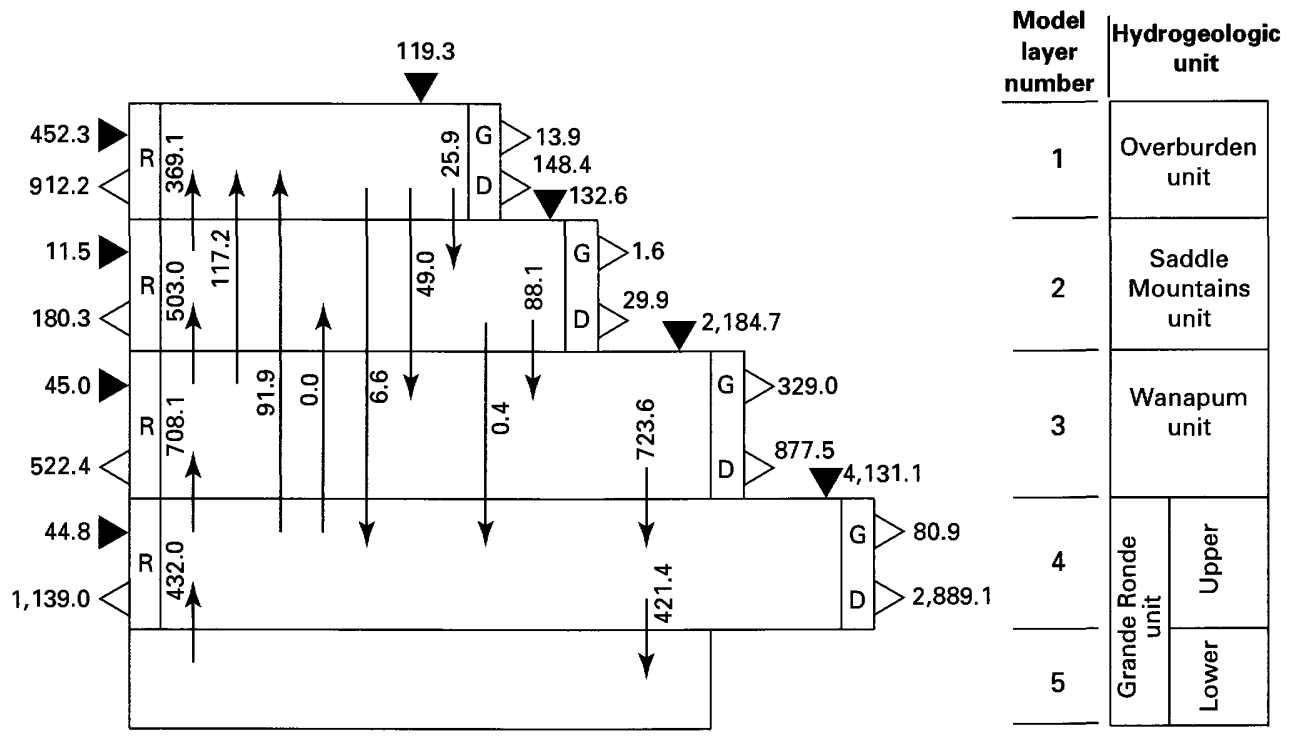

EXPLANATION

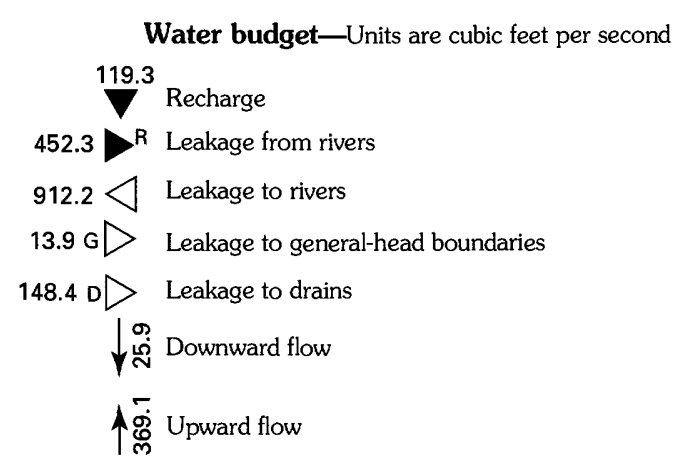

FIGURE 13.-The model-calculated water budget for predevelopment (1850's) land-use conditions, Columbia Plateau aquifer system (From Hansen and others, 1994).

area. Thirty-seven percent of its surface area is exposed at the land surface and received about $4,131 \mathrm{ft}^{3} / \mathrm{s}(4.7$ in/yr) of recharge, of which about 73 percent discharged locally along short- to intermediate-length flow paths. About 28 percent of the recharge reached regional discharge areas. Topography, geologic structure, and surface-water features control the movement of ground water where the unit crops out. In the subsurface, the movement of ground water is controlled by the Wanapum unit's head configuration and dip. Over much of the area where the upper Grande Ronde is buried, the hydraulic head gradient is low or uniform and does not appear to be controlled by structural features as much as in the younger units. The upper Grande Ronde does not appear to be less permeable than overlying units; its lateral hydraulic conductivity values are similar to those of the Wanapum unit. However, like the Wanapum unit, it has lower lateral hydraulic conduc- tivities in the Yakima Fold Belt and in other structurally complex areas.

The lower Grande Ronde covers about $20,110 \mathrm{mi}^{2}$, or 62 percent of the modeled area. It contains about 13,400 $\mathrm{mi}^{3}$ of saturated rock material, which is 52 percent of the total volume of predevelopment saturated aquifer within the ground-water model boundary. This model layer was chosen to represent the deeper flow within the regional aquifer system, and there is almost no regional hydrogeologic information pertaining to it. The layer receives water from and gives water solely to the upper Grande Ronde. The lateral hydraulic conductivity assigned to the lower Grande Ronde is based on the distribution and magnitude of lateral hydraulic conductivity in the upper Grande Ronde and the assumption that the basalts would be less permeable with depth (Hansen and others, 1994). Although the lower unit covers a large area and includes an extensive volume of rock and ground water, only about $422 \mathrm{ft}^{3} / \mathrm{s}$ of ground 
water is estimated to be moving through it. For comparison, the lower Grande Ronde's volume is 100 times greater than that of the saturated overburden aquifer during predevelopment times, but the quantity of water moving through it is only 37 percent of that moving through the overburden aquifer.

\section{CURRENT LAND-USE CONDITIONS}

The calculated water budget for the time-averaged simulation (tables 5 and 6 and fig. 14) shows that about $10,205 \mathrm{ft}^{3} / \mathrm{s}$ (4.24 in/yr) of recharge enters the groundwater system, an increase of $3,640 \mathrm{ft}^{3} / \mathrm{s}(1.52 \mathrm{in} / \mathrm{yr})$ from predevelopment conditions. The additional recharge is mainly due to the delivery, application, and infiltration of applied irrigation water. About $3,202 \mathrm{ft}^{3} / \mathrm{s}$ ( $9.6 \mathrm{in} / \mathrm{yr}$ ) enters the overburden aquifer (an increase of about $\left.3,083 \mathrm{ft}^{3} / \mathrm{s}\right), 577 \mathrm{ft}^{3} / \mathrm{s}(2.6 \mathrm{in} / \mathrm{yr})$ enters the Saddle Mountains unit (a $444 \mathrm{ft}^{3} / \mathrm{s}$ increase), 2,268 $\mathrm{ft}^{3} / \mathrm{s}$ (2.3 in/ yr) enters the Wanapum unit (an $83 \mathrm{ft}^{3} / \mathrm{s}$ increase), and $4,161 \mathrm{ft}^{3} / \mathrm{s}$ ( $\left.4.7 \mathrm{in} / \mathrm{yr}\right)$ enters the upper Grande Ronde (a $30 \mathrm{ft}^{3} / \mathrm{s}$ increase; see table 6).

There is about $400 \mathrm{mi}^{3}$ of water in storage in the aquifer system under current land-use conditions; as a comparison, Franklin D. Roosevelt Lake, created by the construction of Grande Coulee Dam, has about $2.8 \mathrm{mi}^{3}$ of water in storage. However, owing to the control exerted by the hydraulic characteristics and geometry of the aquifer system, the fact that much of the recharge is discharged locally in short flow paths, and based on the observed water-level declines and relative age of the ground water, all the recharge cannot be considered water available for use. Usable storage in the aquifer system, based on the estimated predevelopment to current decrease in storage (about 2,400 $\mathrm{ft}^{3} / \mathrm{s}$ ), is on the order of 0.5 to $1 \mathrm{mi}^{3}$.

Of the total recharge to all units, about $5,595 \mathrm{ft}^{3} / \mathrm{s}$ (55 percent) discharges to drains and about $3,804 \mathrm{ft}^{3} / \mathrm{s}$ (37 percent) discharges to rivers (table 5). Discharge through seepage-face boundaries is only 4 percent of the recharge and is about the same as under predevelopment conditions. Pumpage is about $1,135 \mathrm{ft}^{3} / \mathrm{s}$, or about 11 percent of the recharge. Two interrelated facts can be noted here: overall discharge exceeds recharge by 7 percent, and, because ground-water pumpage locally exceeds the sum of recharge and ground-water inflow, water levels have declined locally. The leakage from rivers and the decrease in storage provide for the excess discharge. Although these two quantities are small, they are important locally as sources of water. For example, the decrease in storage from spring 1983 to spring 1985 amounts to about 16 percent of the ground-water pumpage. Along parts of Crab Creek and within the Odessa-Lind pumping center, river leakage and decrease in storage provide water for ground-water irrigation. Similarly, leakage from the Umatilla River in Oregon locally appears to supply water for groundwater pumpage.

About 110 percent of the recharge to the overburden aquifer discharges to drains and rivers. Leakage from rivers and from underlying basalts supplies an additional $1,144 \mathrm{ft}^{3} / \mathrm{s}$ of water to the overburden aquifer (table 6). The leakage of water from the overburden aquifer to underlying basalts is about $500 \mathrm{ft}^{3} / \mathrm{s}$. Thus, the difference between the quantity of water moving into and out of the bottom of the overburden aquifer indicates that only about 7 percent of the overburden discharge from the aquifer system is flow received from underlying basalt units. About 7 percent of the total overburden aquifer discharge is ground-water pumpage.

Of the approximately $577 \mathrm{ft}^{3} / \mathrm{s}(2.6 \mathrm{in} / \mathrm{yr})$ of recharge to the Saddle Mountains unit, about 47 percent discharges locally and the remainder discharges along intermediate-length flow paths or moves to other units. Leakage to overlying and underlying layers exceeds the leakage from those layers to the Saddle Mountains unit by about $39 \mathrm{ft}^{3} / \mathrm{s}$. Pumpage from the Saddle Mountains unit amounts to only about 7 percent of the recharge. However, pumpage is locally important, as can be seen by the change in storage (table 6), which is about 30 percent of the pumpage.

The Wanapum unit receives about $2,268 \mathrm{ft}^{3} / \mathrm{s}(2.2$ in/yr) of recharge, of which about 48 percent discharges locally, slightly less than under predevelopment conditions. About 12 percent of the Wanapum unit's total discharge is pumpage, and about 43 percent is discharge to other layers. The change in storage is about 25 percent of the Wanapum unit's pumpage. Leakage to seepageface boundaries (part of the local discharge) from the Wanapum unit, although only about 14 percent of recharge, is nearly 70 percent of the pumpage and is, thus, an important budget item. The Wanapum unit has a net loss of water to the overlying overburden aquifer and Saddle Mountains unit of about $111 \mathrm{ft}^{3} / \mathrm{s}$, which is about $373 \mathrm{ft}^{3} / \mathrm{s}$ less than under predevelopment conditions. There is a net loss to the upper Grande Ronde of about $230 \mathrm{ft}^{3} / \mathrm{s}$, which is about $215 \mathrm{ft}^{3} / \mathrm{s}$ more than under predevelopment conditions.

The upper Grande Ronde discharges about 2,970 $\mathrm{ft}^{3} / \mathrm{s}$ locally along short-to intermediate-length flow paths; this is about 51 percent of the unit's total discharge and about 70 percent of its recharge. The ground-water pumpage for the upper Grande Ronde unit is only about 6 percent of its discharge. In comparison to the Wanapum unit, the upper Grande Ronde's larger ground-water storage reservoir and greater lat- 

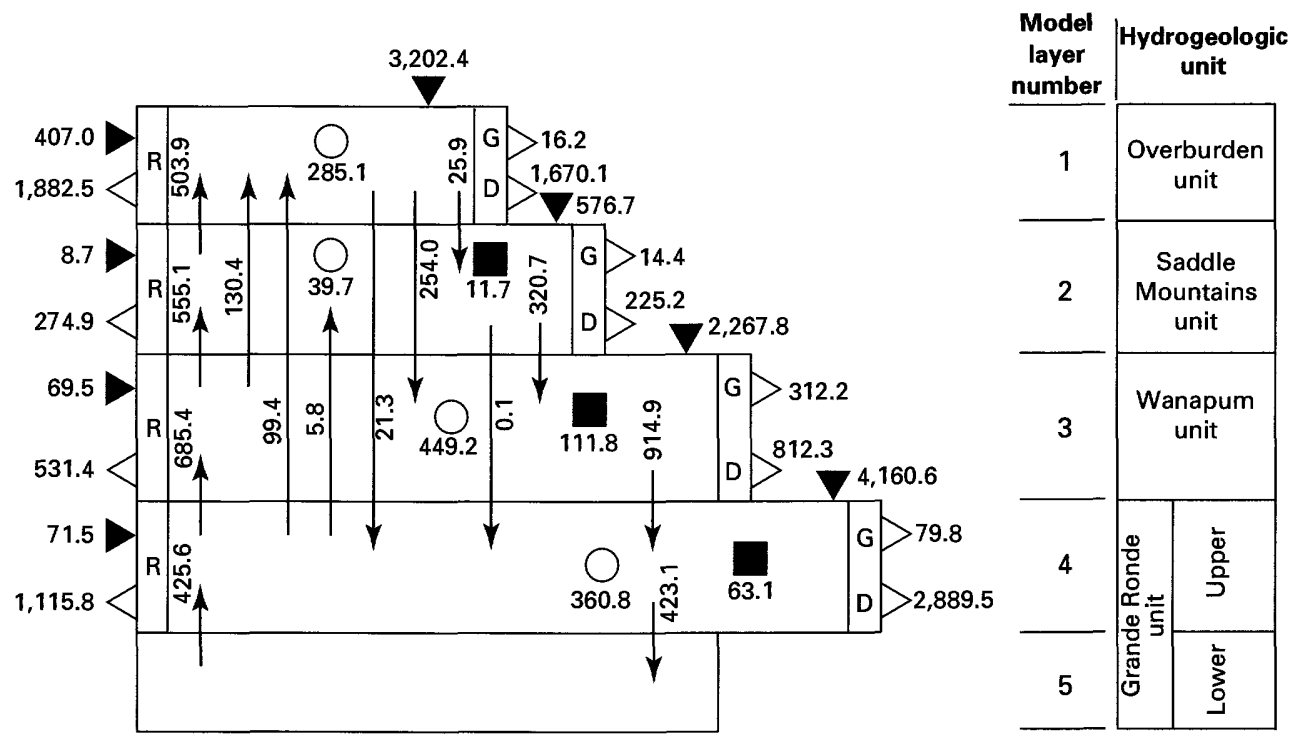

\section{EXPLANATION}

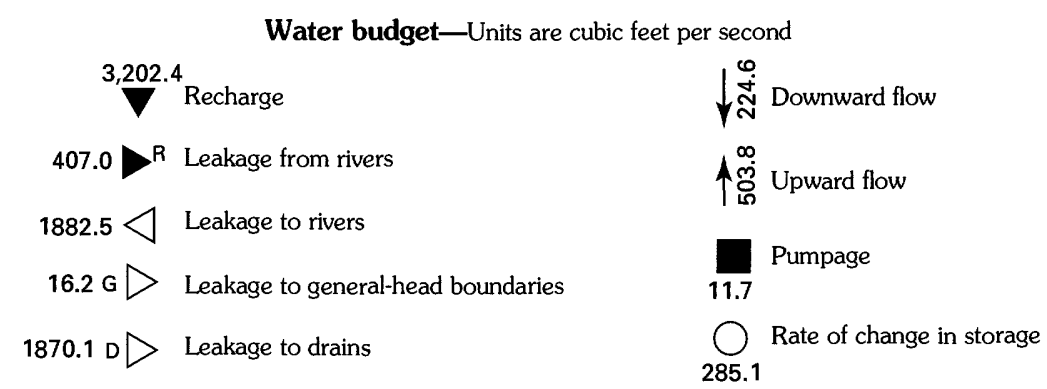

Figure 14.-The model-calculated water budget for current (1980's) land-use conditions, Columbia Plateau aquifer system (From Hansen and others, 1994).

eral ground-water inflow in areas of pumpage have resulted in smaller water-level declines. Thus, the loss in storage is only about 17 percent of the pumpage and 2 percent of the recharge. Pumpage is compensated for primarily by vertical leakage from the overlying Wanapum unit and secondarily from decrease in storage, increase in recharge, and increase in leakage from rivers (table 6).

The water budget and flow system for the lower Grande Ronde are similar to those under predevelopment conditions; differences mainly relate to local changes in lateral head gradient and the vertical head gradient between it and the upper Grande Ronde.

The total quantity of ground water that moves between layers is about $4,565 \mathrm{ft}^{3} / \mathrm{s}$, or about 45 percent of the time-averaged recharge (fig. 14). The remaining 55 percent of recharge remains in the unit it enters and discharges along short flow paths within local flow sys- tems and along intermediate- to regional-length flow paths. Although ground-water travel times are both relatively large and increase with depth, the quantity of water moving between layers indicates an active flow system.

The overburden aquifer has a net gain of about 234 $\mathrm{ft}^{3} / \mathrm{s}$ from underlying units. This water discharges both locally and to the major rivers. Upward flow to the overburden aquifer typically occurs at or near the regional discharge area.

About $1,610 \mathrm{ft}^{3} / \mathrm{s}$ of ground water moves between the Saddle Mountains unit and other units; this quantity is about 280 percent of its recharge. The Saddle Mountains unit loses about $279 \mathrm{ft}^{3} / \mathrm{s}$ to the overburden aquifer and gains about $234 \mathrm{ft}^{3} / \mathrm{s}$ from the underlying basalt units, resulting in a net loss of about $39 \mathrm{ft}^{3} / \mathrm{s}$. Under predevelopment conditions, the unit had a net gain of about $71 \mathrm{ft}^{3} / \mathrm{s}$ from the other layers (table 6). 
About $2,860 \mathrm{ft}^{3} / \mathrm{s}$ of ground water (126 percent of its recharge) moves between the Wanapum unit and other units. Of this quantity, about $1,260 \mathrm{ft}^{3} / \mathrm{s}$ is water gained from other units and about $1,601 \mathrm{ft}^{3} / \mathrm{s}$ is water lost to other units, or a net loss of water from the unit of about $341 \mathrm{ft}^{3} / \mathrm{s}$. About 45 percent of the gains are from overlying units and about 55 percent are from the upper Grande Ronde unit. Leakage to the overlying units and to the upper Grande Ronde is about 43 and 57 percent of the losses, respectively. As a result, the overburden aquifer, Saddle Mountains unit, and upper Grande Ronde have a net gain from the Wanapum unit. The first two units receive most of the gain, mainly at or near the regional discharge area, and this gain is about 75 percent less than under predevelopment conditions. The upper Grande Ronde gains about 93 percent more than under predevelopment conditions.

About $2,576 \mathrm{ft}^{3} / \mathrm{s}$ of ground water (about 62 percent of its recharge) moves between the upper Grande Ronde and other units, about 8 percent more than under predevelopment conditions. As a result of changes in the regional flow system, the upper Grande Ronde has a net gain in ground water of about $149 \mathrm{ft}^{3} / \mathrm{s}$; under predevelopment conditions, this unit had a net loss of about $68 \mathrm{ft}^{3} / \mathrm{s}$.

The total simulated quantity of water moving through both the top and bottom of each aquifer unit (excluding recharge), from youngest to oldest, is about $1,234 \mathrm{ft}^{3} / \mathrm{s}, 1,610 \mathrm{ft}^{3} / \mathrm{s}, 2,860 \mathrm{ft}^{3} / \mathrm{s}, 2,576 \mathrm{ft}^{3} / \mathrm{s}$, and 850 $\mathrm{ft}^{3} / \mathrm{s}$. The units listed in order of flow are Wanapum unit, upper Grande Ronde, Saddle Mountains unit, Overburden aquifer, and lower Grande Ronde, respectively. The upper three units are more active than under predevelopment conditions. For example, the overburden aquifer has about $574 \mathrm{ft}^{3} / \mathrm{s}$ more water moving between it and underlying units and the Saddle Mountains unit has $623 \mathrm{ft}^{3} / \mathrm{s}$ more water moving between it and other layers (table 6).

\section{EFFECTS OF HISTORICAL WATER- DEVELOPMENT PRACTICES}

The aquifer system is a dynamic system that is constantly receiving and discharging water. When recharge to and discharge from the aquifer system are equal, the ground-water system is in equilibrium and water levels remain constant from year to year. If recharge exceeds discharge, water levels rise; if discharge exceeds recharge, water levels decline. Water-level changes, in turn, reflect changes in the quantity of ground water in storage. Excluding climatic effects, changes in recharge and discharge are caused by water-development practices.
Water-development practices include ground-water pumpage, application of most of the pumpage to croplands, delivery and application of surface water to croplands, alterations in land use (including the agricultural practice of fallowing nonirrigated croplands), and the construction of dams. The changes in recharge and discharge on the plateau caused by these practices, in turn, result in changes in water levels.

The net regional effect of water-development practices can be seen by comparing the information presented in table 5 for the regional aquifer system and in table 6 for the model layers. The largest single change in the regional water budget was an increase in recharge of about $3,640 \mathrm{ft}^{3} / \mathrm{s}$ (table 5). The increase is due to the infiltration of delivered and applied surface water. The increased recharge is more than balanced by leakage to rivers ( 29 percent of increased recharge), leakage to drains (45 percent of increased recharge), and groundwater pumpage (31 percent of increased recharge). Most of the increased recharge enters the overburden aquifer (about 84 percent) and a smaller quantity enters the Saddle Mountains unit (12 percent). Therefore, these two units have been affected most by increased recharge due to water-development practices. Correspondingly, the largest increases in leakage to rivers and drains occur within these two units. The changes in recharge and leakage to rivers and drains for the Wanapum unit and the upper Grande Ronde are minor compared with changes for the overburden aquifer and the Saddle Mountains unit. However, leakage to drains from the Wanapum unit has decreased by about 8 percent, whereas it increased for the rest of the system. This decrease represents a net loss of streamflow resulting from ground-water pumpage.

The flow between layers has been changed as a result of the increased recharge in the overburden aquifer and Saddle Mountains (table 6). The Wanapum unit now receives four times more water from these units because they overlie the Wanapum unit in the areas with the largest increases in recharge. Thus, the largest changes in water-budget components for the Wanapum unit occur in the quantity of water it receives from the overlying units and the additional water it provides to the upper Grande Ronde. The spatial distribution of these changes, combined with the effects of groundwater pumpage, has caused water-level changes.

The difference between model-calculated water levels for the time-averaged and the predevelopment simulations shows the simulated water-level changes that have occurred as a result of water-development practices. These model-calculated changes are in general agreement with data from local studies. Model-calculated water-level changes are shown on figure 15 for the 


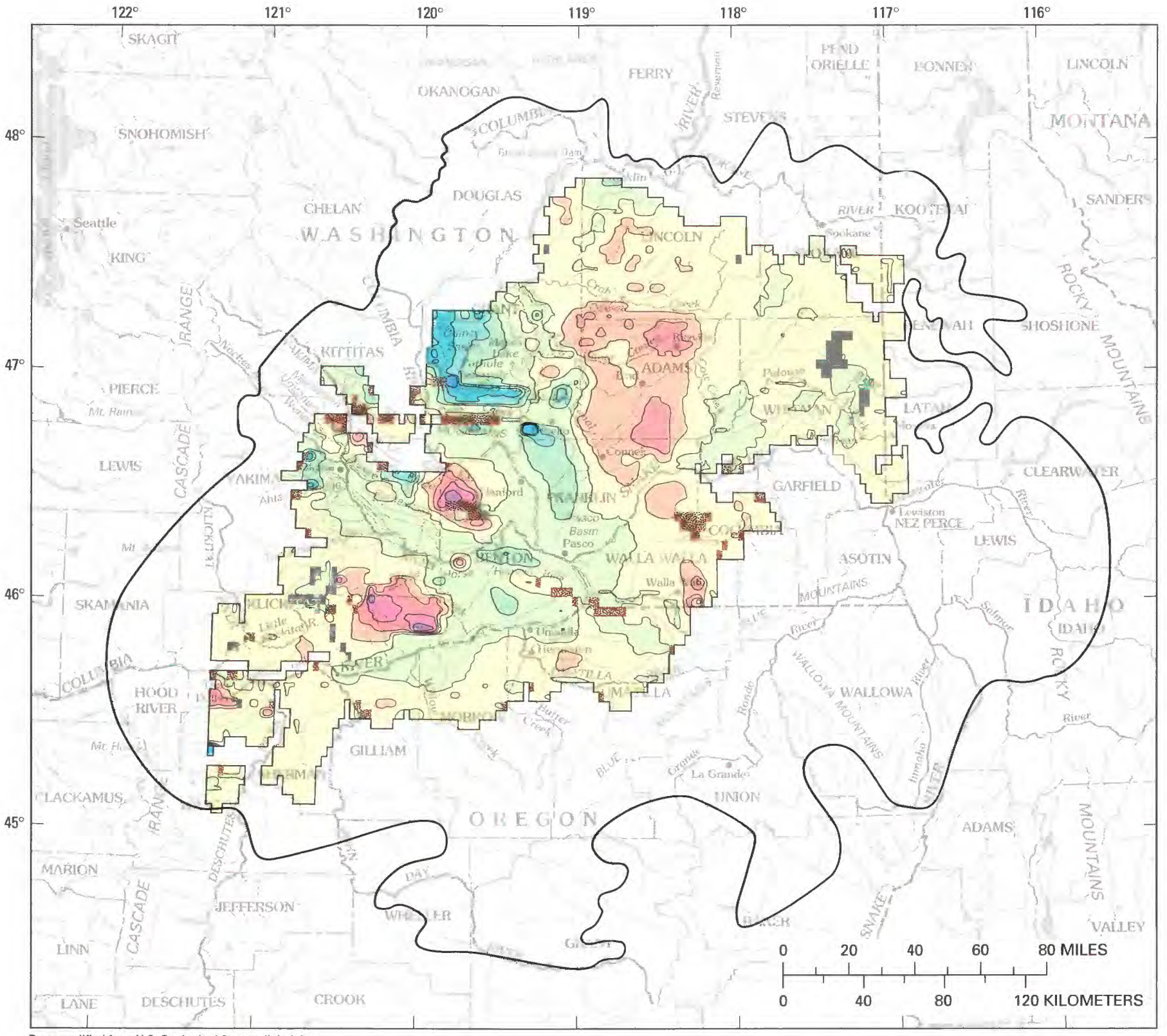

Base modified from U.S. Geological Survey digital data, 1:2,000,000, 1972

Water level change, in feet

Rise of more than 400

Decline of $200-300$

Rise of $300-400$

Decline of $300-400$

ए Rise of 200-300

Rise of $100-200$

Rise of $0-100$

Decline of $0-100$

Decline of $100-200$

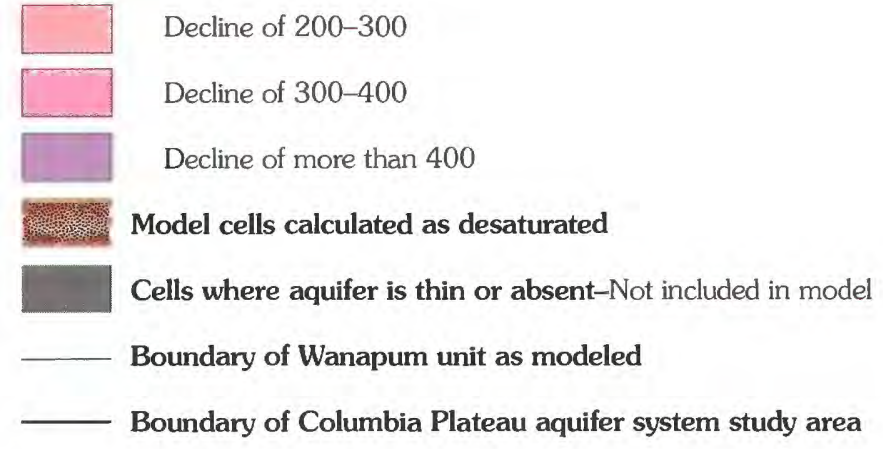

FIGURE 15.-Model-calculated water-level changes in the Wanapum unit from predevelopment to present (1980's). 
Wanapum unit; the patterns of change are generally similar in the other units.

For the overburden aquifer, there has been a median water-level rise of about $12 \mathrm{ft}$. The rises have led to the saturation of about $32 \mathrm{mi}^{3}$ of sediments (an increase of water in storage of about 10 million acre- $\mathrm{ft}$ ). The overburden aquifer has been saturated throughout an additional $1,600 \mathrm{mi}^{2}$ where the sediments previously were unsaturated. These changes were caused by the increased recharge, which in turn is a result of the infiltration of applied surface water to croplands; the surface-water application rate averages about $4 \mathrm{ft} / \mathrm{yr}$ on the plateau. The largest changes have occurred in the CBIP, where water-level rises are as much as $300 \mathrm{ft}$. Rises have not been as large in the extensively surfacewater-irrigated Yakima River basin because water levels were already near land surface and most of the overburden was already saturated in this basin. Thus, most rises there have been generally less than about $10 \mathrm{ft}$. Water-level declines have occurred in only a few locations within the overburden aquifer. The model indicates some local declines, on the order of $10 \mathrm{ft}$, in the Wenas Creek valley (tributary to the Yakima River). Declines of as much as $40 \mathrm{ft}$ also are indicated along the eastern edge of the overburden aquifer in the Walla Walla River basin where the overburden aquifer is pumped. Throughout the remaining part of the Walla Walla River basin, water levels have risen 5 to $30 \mathrm{ft}$.

As with the overburden aquifer, throughout much of the extent of the Saddle Mountains unit water levels have risen; the average and median rise are about 65 and $20 \mathrm{ft}$, respectively. The rises have, in turn, saturated about $23 \mathrm{mi}^{3}$ (an increase of water in storage of about 1.6 million acre- $\mathrm{ft}$ ) of the Saddle Mountains unit, as well as an additional area of about $839 \mathrm{mi}^{2}$ where the sediments previously were unsaturated. The largest rises have occurred within the lower CBIP north of Pasco, Wash., where rises have exceeded $300 \mathrm{ft}$. Rises have occurred throughout the extent of this unit where it underlies the valley floor in the Yakima River basin. Because water levels are near land surface, the rises in the Yakima basin have been smaller than those in the CBIP. However, larger rises, as much as $100 \mathrm{ft}$ or so, have occurred where the overburden aquifer is thin or absent and in tributary valleys of the Yakima River. Rises also have occurred along the Columbia River in both Oregon and Washington between the Umatilla River and Willow Creek. Except for some places along the Columbia River where dams have an effect, the rises result from surface-water irrigation. Water-level declines have been small and local, mainly in small valleys within the Yakima Fold Belt.

The general effect of water development on the overburden aquifer and the Saddle Mountains unit has been to raise the water-level altitudes throughout most of their extent. Declines in these units have been local and small. This is because little water is pumped from the Saddle Mountains unit, and the water pumped from the overburden aquifer is generally from areas of surface-water irrigation. In those areas, the pumpage typically is derived from stored water from irrigation recharge and water in streams, canals, and irrigation drains.

Water-level rises and declines in the Wanapum unit have been much more widespread (fig. 15). In areas of intensive surface-water irrigation, such as the Yakima River valley, CBIP, and parts of Oregon between the Umatilla River and Willow Creek, water levels have risen. These rises average about $55 \mathrm{ft}$ (median of $10 \mathrm{ft}$ ) and range from 1 to more than $300 \mathrm{ft}$. The area affected by rises is some $6,600 \mathrm{mi}^{2}$ (about 35 percent of the unit's area), although the area with rises greater than about 10 $\mathrm{ft}$ is some $3,930 \mathrm{mi}^{2}$. Water-level rises are smaller where the regional streams are near the top of the Wanapum unit. Rises are larger in upland areas where the top of the Wanapum unit is above the regional streams. In these areas, water levels in the Wanapum unit were already above the regional streams, increasing lateral head gradients due to the hydraulic characteristics of the rock materials.

The East Low Canal (fig. 1) marks the general boundary in the central plateau between water-level rises in the Wanapum unit to the west and water-level declines in the Wanapum unit to the east. Water levels began to rise with the completion of the canal and importation and application of Columbia River water in the early 1950's for the CBIP; in most areas water levels had stabilized to a new equilibrium by the mid-1970's. The hydrographs of wells $14 \mathrm{~N} / 29 \mathrm{E}-27 \mathrm{E} 01$ and 19N/ 23E-34R01 (fig. 16) illustrate this steady rise. The largest rises have occurred in the Quincy basin, as much as 300 $\mathrm{ft}$, and in areas southeast and northeast of Potholes Reservoir, as much as $150 \mathrm{ft}$.

Water levels declined in the Wanapum unit throughout about $13,400 \mathrm{mi}^{2}$ (about 65 percent of the area); declines were greater than about $10 \mathrm{ft}$ in about 7,450 $\mathrm{mi}^{2}$. Water-level declines, resulting from pumping ground water for irrigation, began in the 1960's and are concurrent with the increase in irrigated acreage. The initial declines were in five areas: (1) western Adams and southern Lincoln Counties, Wash. (the Odessa-Lind pumping center), (2) Walla Walla River basin, Wash., (3) the Pullman-Moscow area in Washington and Idaho, (4) The Dalles, Oreg., and (5) the Hermiston, Oreg. area (fig. 1). Water levels began to decline in the Horse Heaven Hills in the early 1970's. Declines average about $60 \mathrm{ft}$ (median value of about $9 \mathrm{ft}$ ) and in places have exceeded $200 \mathrm{ft}$. The largest declines occur in the 

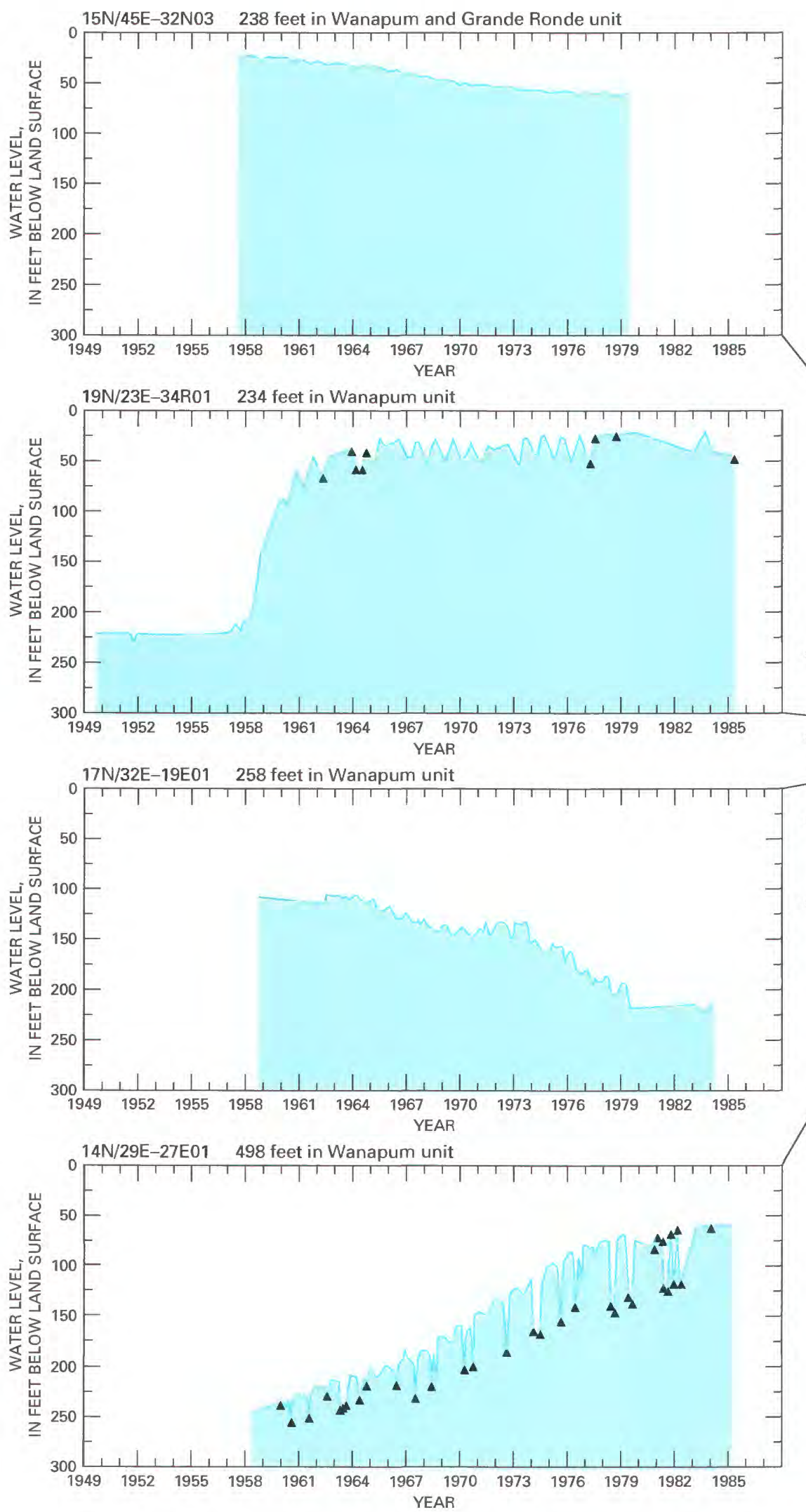

\section{EXPLANATION}

19N/23E-34R01 Well number

$4 \quad$ Non-static water level

Note: Water-level fluctuations due to pumping

Figure 16.-Hydrographs of selected wells showing long-term water-level changes. 
Odessa-Lind pumping center, within some of the valleys in the Yakima Fold Belt, on the south slope of Horse Heaven Hills, in the pumping center near Umatilla, Oreg., and in the Walla Walla River basin (fig. 15). The hydrographs of wells $15 \mathrm{~N} / 45 \mathrm{E}-32 \mathrm{~N} 03$ and $17 \mathrm{~N} / 32 \mathrm{E}-$ 19E01 (fig. 16) illustrate some of these declines. In general, water levels in those areas continue to decline, and the size of the areas affected has increased with time. The rate of water-level decline, however, has decreased, at least in the central part of the plateau (Lane and Whiteman, 1989).

In several of these areas, the declines have been moderated by the rising water levels in nearby surfacewater irrigated areas. These rises have increased gradient, and thus supply additional water to the pumping centers. A good example of this is the narrow transition zone between water-level rises in the CBIP and waterlevel declines beginning just east of the East Low Canal and extending into the Odessa-Lind area. Simulation, using the predevelopment model, of the affects of the additional recharge resulting from the surface-water irrigation indicated a water-level rise of 10 to $100 \mathrm{ft}$ over a large part of the Odessa-Lind pumping center.

The effects of water development on the upper Grande Ronde have been to raise water levels over about half of its area and to lower water levels over the remainder. Rises have averaged about $30 \mathrm{ft}$ (median of about $14 \mathrm{ft}$ ) and declines have averaged about $35 \mathrm{ft}$ (median of about $6 \mathrm{ft}$ ). Model-calculated rises and declines are in excess of $200 \mathrm{ft}$. The rises have occurred in the surface-water-irrigated areas and along the manmade reservoirs of the major rivers. The largest rises have occurred in the Quincy basin. Declines have occurred in areas of ground-water pumping, mainly centered in the Odessa-Lind area of Washington and the Umatilla area of Oregon. Smaller scale declines have occurred in the Pullman-Moscow area and in the Horse Heaven Hills area. Local declines have also occurred throughout the plateau.

Projected rises and declines in the lower Grande Ronde cannot be verified because there are no data. The model-calculated water-level changes are only a preliminary and coarse estimate of the effects of water development on the deep flow system. The largest modelcalculated rises, up to about $150 \mathrm{ft}$, are in the northwest Quincy basin. Smaller rises are indicated in other surface- water-irrigated areas and along the major rivers. Declines of as much as $170 \mathrm{ft}$ are calculated for the Odessa-Lind area in Washington, and as much as $50 \mathrm{ft}$ for the Umatilla, Oreg., area. The distribution of rises and declines for the lower Grande Ronde are similar to those for the upper Grande Ronde, but the magnitude of these changes is less. As with the upper Grande Ronde, declines in the lower Grande Ronde have spread north and east from the Odessa-Lind area and the southern extent of declines is delineated by a narrow east-west strip of low hydraulic conductivity that extends eastward from the Saddle Mountains anticline to the vicinity of the mouth of the Palouse River.

Water-level rises and declines of more than a few feet affect regional patterns of ground-water movement. The dominant direction of ground-water movement across the northern half of the plateau prior to the development of an agriculture-based economy was simulated as south-westerward, from the northern and eastern plateau margins toward the Columbia and Snake Rivers. The complex pattern of flow in this area, mapped for the Wanapum unit (fig. 7) and simulated for current conditions, reflects the combined effects of water-level rises and declines.

The effects of water development in 27 selected basins (table 7) were analyzed through the model-calculated changes in ground-water discharge (Hansen and others, 1994). Ground-water discharge decreased in about half the basins; some of the decreases were small. Ground-water discharge in the other basins either remained about the same or increased in comparison to results for simulated predevelopment conditions. Largest decreases were in the Cow Creek, upper Crab Creek, Bowers Coulee, South Fork Palouse River, and Little Klickitat River basins. For example, ground-water discharge in Cow Creek basin decreased from about $41 \mathrm{ft}^{3} /$ $\mathrm{s}$ under predevelopment conditions to about $23 \mathrm{ft}^{3} / \mathrm{s}$ under 1983-85 conditions. Similarly, the discharge in Crab Creek basin decreased by about $38 \mathrm{ft}^{3} / \mathrm{s}$, from 63 to $25 \mathrm{ft}^{3} / \mathrm{s}$. Ground-water discharge increased in several of the basins, although only in Glade Creek, in Washington, was the percentage of increase large, from 0 to $7.9 \mathrm{ft}^{3} / \mathrm{s}$

In the model analysis by Hansen and others (1994), ground-water discharge to 16 selected stream reaches was calculated (table 8 ). The model-calculated groundwater discharge to 7 of the 16 selected stream reaches has increased significantly due to water development. The seven reaches are the upper Columbia River, lower and upper Yakima River, lower Crab Creek, Walla Walla River, Naches River, and the Rocky Ford-Crab Creek. The upper Columbia River receives an additional 540 $\mathrm{ft}^{3} / \mathrm{s}$ of ground-water discharge when compared with predevelopment conditions. This increase is caused by the rise in water levels in CBIP. This quantity is insignificant when compared with the flow in the Columbia River. The upper Yakima River now is estimated to receive about $304 \mathrm{ft}^{3} / \mathrm{s}$ of ground-water discharge, an increase of about $118 \mathrm{ft}^{3} / \mathrm{s}$. The calculated ground-water discharge to the lower Yakima River has increased from about $45 \mathrm{ft}^{3} / \mathrm{s}$ to about $425 \mathrm{ft}^{3} / \mathrm{s}$. The model calculations indicate that the Yakima River now receives about 500 
TABLE 8.-Model-calculated ground-water discharge to selected stream reaches, Columbia Plateau aquifer system (from Bauer and Hansen, in press) [Values in cubic feet per second; CBIP, Columbia Basin Irrigation Project]

\begin{tabular}{|c|c|c|c|c|c|c|c|}
\hline \multirow[b]{3}{*}{ Stream reach } & \multirow[b]{3}{*}{ Predevelopment } & \multirow[b]{3}{*}{$\begin{array}{c}1983-85 \\
\text { time-averaged }\end{array}$} & \multirow[b]{3}{*}{$\begin{array}{l}\text { 1983-85 } \\
\text { equilibrium }\end{array}$} & \multicolumn{4}{|c|}{ CBIP expansion } \\
\hline & & & & \multicolumn{2}{|c|}{ Phase 1} & \multicolumn{2}{|c|}{ Phases 1 and 2} \\
\hline & & & & $\begin{array}{c}\text { 1983-85 } \\
\text { pumpage }\end{array}$ & $\begin{array}{l}\text { Reduced } \\
\text { pumpage }\end{array}$ & $\begin{array}{c}\text { 1983-85 } \\
\text { pumpage }\end{array}$ & $\begin{array}{l}\text { Reduced } \\
\text { pumpage }\end{array}$ \\
\hline Upper Columbia River & 291.1 & 831.4 & 827.1 & 840.8 & 842.6 & 850.6 & 857.4 \\
\hline Snake River & 491.7 & 435.5 & 428.0 & 433.0 & 434.9 & 449.0 & 456.1 \\
\hline Lower Yakima River & 45.3 & 424.8 & 417.9 & 418.2 & 418.3 & 418.9 & 419.4 \\
\hline Lower Columbia River & 383.9 & 354.1 & 333.6 & 333.7 & 333.7 & 333.8 & 334.1 \\
\hline Upper Yakima River & 185.4 & 303.8 & 303.4 & 303.4 & 303.4 & 303.4 & 303.4 \\
\hline Klickitat River & 217.2 & 225.7 & 225.7 & 225.7 & 225.7 & 225.7 & 225.7 \\
\hline Palouse River & 160.4 & 164.3 & 140.5 & 142.6 & 144.0 & 150.1 & 158.1 \\
\hline Lower Crab Creek & 76.3 & 145.1 & 140.3 & 144.6 & 146.9 & 152.2 & 162.8 \\
\hline Walla Walla River & 72.1 & 115.3 & 114.6 & 114.8 & 114.9 & 115.3 & 115.5 \\
\hline Naches River & 54.7 & 97.5 & 95.7 & 95.7 & 95.7 & 95.7 & 95.7 \\
\hline Rocky Ford-Crab Creek & 10.8 & 90.9 & 87.6 & 98.5 & 104.7 & 103.1 & 114.3 \\
\hline Grande Ronde River & 74.0 & 74.0 & 74.0 & 74.0 & 74.0 & 74.0 & 74.0 \\
\hline Spokane River & 52.4 & 51.5 & 51.4 & 51.4 & 51.4 & 51.4 & 51.4 \\
\hline Deschutes River & 47.4 & 50.6 & 50.4 & 50.4 & 50.4 & 50.4 & 50.4 \\
\hline John Day River & 42.5 & 45.9 & 45.6 & 45.6 & 45.6 & 45.6 & 45.6 \\
\hline Moses Coulee & 11.5 & 9.8 & 9.2 & 9.2 & 9.2 & 9.2 & 9.3 \\
\hline
\end{tabular}

$\mathrm{ft}^{3} / \mathrm{s}$ more ground-water discharge than under predevelopment conditions. The increased ground-water discharge is due to return flows resulting from the infiltration of delivered and applied excess surface water. Much of this excess water flows through the overburden aquifer to drains that discharge to the Yakima River; that quantity is not included in the 500 $\mathrm{ft}^{3} / \mathrm{s}$. The $500 \mathrm{ft}^{3} / \mathrm{s}$ is relied upon for meeting downstream water rights. Lower Crab Creek receives an additional $69 \mathrm{ft}^{3} / \mathrm{s}$, as calculated by the model. The increase in ground-water discharge is from irrigation return flow from both CBIP and ground water from the rising water levels in the Wanapum unit. The simulated increase in ground-water discharge to the Walla Walla River was about $43 \mathrm{ft}^{3} / \mathrm{s}$; the increase is due to surfacewater irrigation. The calculated ground-water discharge to the Naches River has increased from about $55 \mathrm{ft}^{3} / \mathrm{s}$ to $98 \mathrm{ft}^{3} / \mathrm{s}$, due to surface-water irrigation in the Naches River basin. Last, the Rocky Ford-Crab Creek area (defined as the area around Potholes Reservoir, fig. 1) has a calculated increase of about $80 \mathrm{ft}^{3} / \mathrm{s}$ (from $11 \mathrm{ft}^{3} / \mathrm{s}$ for predevelopment conditions to $\left.91 \mathrm{ft}^{3} / \mathrm{s}\right)$. This increased discharge also is due to the application of surface water in the CBIP. Each of these seven stream reaches crosses part of the areas of calculated rises in water levels.

Generally, ground-water discharge to the stream reaches does not appear to have decreased significantly. However, decreases in discharge to streams have occurred both in the selected basins analyzed and for some of the model drain cells not included in the basins.

\section{EFFECTS OF POTENTIAL WATER- MANAGEMENT ALTERNATIVES}

The ground-water model was used principally to obtain a better understanding of the regional groundwater flow system and the relation between the various components of the flow system. However, five steadystate simulations also were completed to estimate the effects of potential water-management alternatives (Bauer and Hansen, in press).

The first simulation was made to estimate the longterm effects of the 1983-85 distribution of pumpage and recharge; the time-averaged model was used without the 1983-85 change-in-storage term. This simulation represents the long-term, 1983-85 equilibrium conditions under current water-management strategies.

The other four simulations were made to estimate the effects of the proposed further development (expansion) of CBIP. The expansion area covers most of the Odessa-Lind pumping center in Washington. The CBIP originally was authorized for the development of $1,095,000$ acres to receive Columbia River water; about 556,000 acres currently are developed. Under the proposed expansion, the remaining 538,500 acres would be developed. 
On the basis of information from the Water Conservation Steering Committee (1987), the expansion would proceed in two phases, and there are several proposed alternatives for each phase. The existing Alternative A phase 1 (about 160,000 acres) and phase 2 (about 378,500 acres) developments were chosen for simulation. Each phase of development $(160,000$ acres for phase 1 and 538,500 acres for phases 1 and 2) was simulated under an annual irrigation-application rate of 4.0 $\mathrm{ft} / \mathrm{yr}$, the estimated average current operating rate for CBIP.

On the basis of the observed historical water-level rises in CBIP, it is estimated that drains would be needed at every model cell with new surface-water application; therefore, drains were added to all these model cells. Additionally, recharge to those cells caused by the infiltration of the surface water delivered and applied to croplands was estimated from the information presented in Bauer and Vaccaro (1990). Climate, and thus ground-water recharge, was assumed to be invariant, and because the simulations were steadystate, a time-history of the effects was not examined.

For two of the four simulations, phase 1 and phase 1 plus 2, 1983-85 pumpage was kept the same. For the other two simulations the pumpage was reduced for a ground-water model cell in proportion to the percentage of area of the cell included in the proposed CBIP expansion. In order to isolate the effects of the proposed expansion of CBIP, the model results (discussed later in this section) were referenced to the calculated 1983-85 equilibrium conditions.

\section{EQUILIBRIUM CONDITIONS}

The first simulation, representing the long-term effects of 1983-85 water-management strategies, indicated that the largest changes in the flow system would occur in the Wanapum unit. The water budget and water-level configuration calculated by the model for the overburden aquifer remained about the same; continued pumpage from this unit slightly decreased the quantity of water discharging from it to drains.

The effects on the Saddle Mountains unit were limited to the Yakima Fold Belt in the Moxee-Selah-Cold Creek tributary valleys and to the western part of Horse Heaven Hills. The water-level configuration and water budget would remain nearly the same throughout the remainder of the Saddle Mountains unit. For the areas in the Yakima Fold Belt, calculated water-level declines would exceed $100 \mathrm{ft}$ and some areas would become unsaturated. This is due to the pumping from both the Saddle Mountains unit and the underlying Wanapum unit. The declines would extend throughout some 80 $\mathrm{mi}^{2}$, and the model calculated the desaturation of some $160 \mathrm{mi}^{2}$ of the unit. The model-calculated desaturated areas generally are areas where the unit is thin, presently is saturated, receives only a small quantity of recharge, and has little to no potential for lateral inflow (small upgradient contributing area).

The model-derived estimates of changes in water levels (all declines) from the 1983-85 simulation for the Wanapum unit (fig. 17) show that the largest declines would occur in the Odessa-Lind pumping center, near The Dalles, Oreg., near Butter Creek, Oreg., near Glade Creek, Wash., on the south slope of Horse Heaven Hills, and in the Moxee-Selah-Cold Creek tributary valleys within the Yakima Fold Belt; calculated declines in those areas are generally less than $200 \mathrm{ft}$, but exceed 500 $\mathrm{ft}$ locally. The areal extent of the declines is large: $1-$ to 75 -foot declines cover about $200 \mathrm{mi}^{2}$; 75- to 150 -foot declines, about $180 \mathrm{mi}^{2}$; and model cells that desaturate, some $400 \mathrm{mi}^{2}$. About 4 percent of the area of the Wanapum unit is affected by declines. In the OdessaLind pumping center alone, about 20 model cells were calculated as desaturating, indicating desaturation throughout $93 \mathrm{mi}^{2}$ of the Wanapum unit (a decrease in storage of about 350,000 acre-feet of ground water).

Changes in the flow system in the Grande Ronde unit, resulting from continuing the 1983-85 pumpage from the aquifer system, occur principally in parts of the Odessa-Lind pumping center, near Butter Creek, Oreg., and near Glade Creek, Wash., on the Horse Heaven Hills. The water- level declines in the Grande Ronde unit in the Odessa-Lind area extend from south of Odessa to north of Connell and from about the East Low Canal in the west to Ritzville, Wash., in the east; this is about the same area of calculated declines for the Wanapum unit. Unlike the Wanapum unit, however, in only one model cell are calculated declines greater than $75 \mathrm{ft}$. Declines ranging between 1 and $75 \mathrm{ft}$ were calculated to include some $225 \mathrm{mi}^{2}$. In one area in the western part of Horse Heaven Hills, the upper Grande Ronde was calculated as desaturating, but this is believed to have been caused by numerical instability in the model rather than by pumping in that area. The declines in the upper Grande Ronde are paralleled in the lower Grande Ronde, but they are neither as widespread nor as large in magnitude.

The model was used to calculate changes to the water budget of the aquifer system (table 9). The inflow changes are the loss of storage and an additional $20 \mathrm{ft}^{3} /$ $\mathrm{s}$ of streamflow captured. The induced leakage from rivers is due to the lowering of water levels, caused by the current distribution and rate of ground-water pumping. Also, because continued pumping at the current rate causes areas to become desaturated, there was a net loss of about $40 \mathrm{ft}^{3} / \mathrm{s}$ of ground-water pumpage. It is esti- 


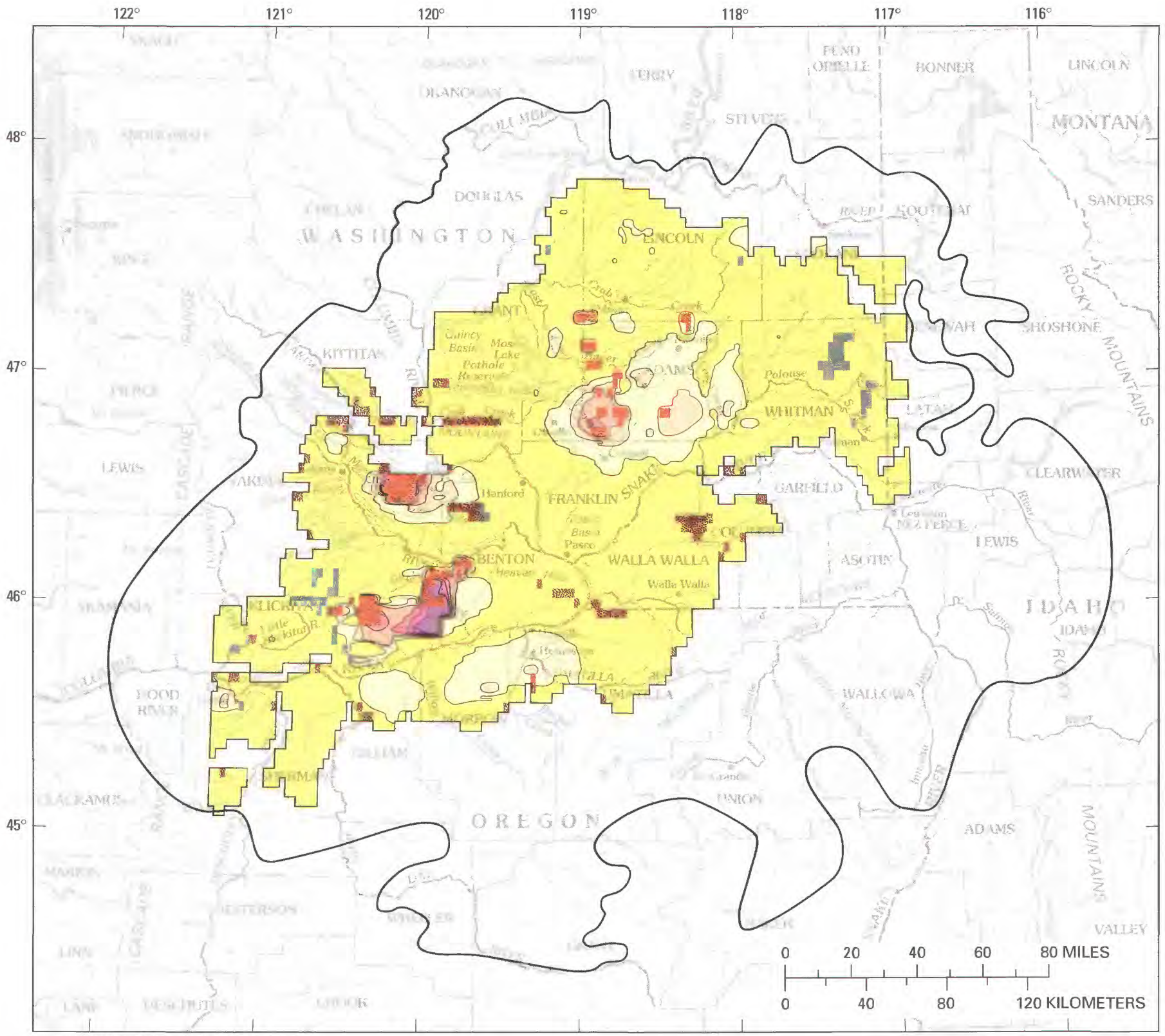

Base modified from U.S. Geological Survey digital data, $1: 2,000,000,1972$

Water level change, in feet

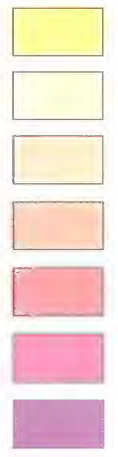

Decline of $0-10$

Decline of $10-50$

Decline of $50-100$

Decline of $100-200$

Decline of $200-300$

EXPLANATION

Decline of $300-400$

Model cells calculated as desaturated under current conditions

Model cells calculated as becoming desaturated under future equilibrium conditions

Cells where aquifer is thin or absent-Not included in model

Boundary of Wanapum unit as modeled

Decline of more than 400

FIGLRE 17.-Calculated water-level changes in the Wanapum unit from 1985 to equilibrium conditions, based on current water-management strategies. 
TABLE 9.-Model-calculated changes in the regional ground-water flow system resulting from simulation of potential water-management alternatives, Columbia Plateau aquifer system (from Bauer and Hansen, in press)

[Values in cubic feet per second]

\begin{tabular}{|c|c|c|c|c|c|c|}
\hline \multirow[b]{3}{*}{$\begin{array}{l}\text { Water-budget } \\
\text { component }\end{array}$} & \multirow{3}{*}{$\begin{array}{c}\text { Calculated } \\
\text { water budget } \\
\text { for time-averaged } \\
1983-85 \text { simulation }\end{array}$} & \multirow{3}{*}{$\begin{array}{c}\begin{array}{c}\text { Time-averaged } \\
\text { simulation }\end{array} \\
\begin{array}{c}\text { Simulated } \\
\text { equilibrium } \\
\text { conditions }\end{array}\end{array}$} & \multicolumn{4}{|c|}{$\begin{array}{l}\text { Calculated change from } \\
\text { equilibrium conditions simulation }\end{array}$} \\
\hline & & & \multicolumn{2}{|c|}{ *Phase 1} & \multicolumn{2}{|c|}{ *Phases 1 and 2} \\
\hline & & & $\begin{array}{c}1983-85 \\
\text { pumpage }\end{array}$ & $\begin{array}{l}\text { Reduced } \\
\text { pumpage }\end{array}$ & $\begin{array}{l}\text { 1983-85 } \\
\text { pumpage }\end{array}$ & $\begin{array}{l}\text { Reduced } \\
\text { pumpage }\end{array}$ \\
\hline Wells (change in storage) & 187 & -187 & 0 & 0 & 0 & 0 \\
\hline Recharge & 10,205 & 0 & 330 & 330 & 974 & 974 \\
\hline Leakage from rivers & 557 & 20 & -13 & -24 & -23 & -38 \\
\hline TOTAL INFLOW & 10,949 & -167 & 317 & 305 & 950 & 935 \\
\hline Wells & 1,135 & -40 & 9 & -121 & 19 & -252 \\
\hline Leakage to rivers & 3,804 & -78 & 32 & 44 & 72 & 120 \\
\hline Leakage to drains & 5,596 & -47 & 272 & 377 & 858 & 1,060 \\
\hline Leakage to seepage faces & 423 & -2 & 3 & 4 & 5 & 6 \\
\hline TOTAL OUTFLOW & 10,958 & -167 & 316 & 305 & 954 & 934 \\
\hline
\end{tabular}

* Simulated phased expansion of CBIP (Columbia Basin Irrigation Project) with 4.0 feet per year surface-water irrigation application rate.

mated that the lowering of water levels would cause a decrease of $78 \mathrm{ft}^{3} / \mathrm{s}$ in leakage to rivers and a decrease of $47 \mathrm{ft}^{3} / \mathrm{s}$ of leakage to drains.

Model-calculated ground-water discharge to the 27 selected basins would remain about the same in all but the Cow Creek basin and, to a lesser extent, Bowers Coulee (table 7). In Cow Creek basin, pumping would reduce ground-water discharge by about 52 percent. Similarly, model-calculated ground-water discharge to the 16 selected stream reaches would be virtually unchanged (table 8), and the largest change would be for the Palouse River.

To summarize, under the assumption of invariant climate, the continuation of the current (1983-85) waterdevelopment practices would cause water-level declines in all basalt units and only minor declines in the overburden aquifer. The declines in the Saddle Mountains unit would be confined to the Horse Heaven Hills and the tributary valleys in the Yakima Fold Belt. Declines in the Wanapum unit would be more widespread and of a much larger magnitude. The areas affected would be the Odessa-Lind pumping center, Horse Heaven Hills, an area near Butter Creek, Oreg., an area near The Dalles, Oreg., and some valleys in the Yakima Fold Belt. Because the current pumping rate would lower water levels if continued, some parts of the aquifer would desaturate, localized leakage would be induced from the streams (reduction in streamflow), and well yields would decline (in some cases the flow to wells would cease).

\section{COLUMBIA BASIN IRRIGATION PROJECT EXPANSION, 1983-85 PUMPAGE}

The simulations estimating the effects of the expansion of CBIP showed large water-level rises from equilibrium conditions. In the CBIP for the phase 1 expansion, about 16 cells that desaturated with continuation of current (1980's) strategies (3 in the Saddle Mountains unit and 13 in the Wanapum unit) would not desaturate because of the additional $330 \mathrm{ft}^{3} / \mathrm{s}$ of recharge (table 9) resulting from the application of surface water for irrigation. This would allow for about 31 $\mathrm{ft}^{3} / \mathrm{s}$ of pumpage to be continued in those cells. Infiltration of the surface water would cause water levels to rise in the aquifer system. The rises in the overburden aquifer would be small because there is little overburden in the expansion areas. Water levels in the Saddle Mountains unit would rise to or near land surface along its eastern extent, throughout about 80 to $90 \mathrm{mi}^{2}$. Calculated rises for the phase 1 expansion occurred principally in the Wanapum unit. Rises of 1 to $100 \mathrm{ft}$ and of 100 to $200 \mathrm{ft}$ in the Wanapum unit would each encompass more than $200 \mathrm{mi}^{2}$. Rises greater than $200 \mathrm{ft}$ would encompass less than about $100 \mathrm{mi}^{2}$. As a result of waterlevel rises, the leakage to rivers would increase by about $32 \mathrm{ft}^{3} / \mathrm{s}$ and leakage to drains would increase by about $272 \mathrm{ft}^{3} / \mathrm{s}$. (Because the drains discharge to the rivers, the net effect of increased leakage to rivers and drains accounts for most of the increase in recharge.) Discharge at seepage faces, generally located at the margins of the units, would not be affected by the proposed expansion. 
The expansion of both phases of CBIP would cause recharge to increase by about $974 \mathrm{ft}^{3} / \mathrm{s}$ (table 9 ). Streamflow in the rivers bordering CBIP would increase by about $40 \mathrm{ft}^{3} / \mathrm{s}$ in addition to the $32 \mathrm{ft}^{3} / \mathrm{s}$ increase under the phase 1 expansion. Drains would receive most $(88$ percent) of the additional recharge water. With full development of CBIP, an additional 14 cells in the Wanapum unit that were simulated to desaturate under the phase 1 management strategy simulation would remain saturated (allowing for the continuation of the $10 \mathrm{ft}^{3} / \mathrm{s}$ of pumpage). Water-level rises would encompass about three times the area under phase 1 alone. Additionally, areas of rises of more than $250 \mathrm{ft}$ would increase, as would areas of water-level rises in the upper Grande Ronde, although these rises would still be generally less than $100 \mathrm{ft}$.

\section{COLUMBIA BASIN IRRIGATION PROJECT EXPANSION, REDUCED PUMPAGE}

For the phase 1 expansion but with a prorated reduction in 1983-85 ground-water pumping, pumpage was estimated to be reduced by about $121 \mathrm{ft}^{3} / \mathrm{s}$ (table 9 ). This results in a slightly different flow system than under the phase 1 expansion with continuation of 198385 pumpage. The inflow into the aquifer system (table 9) would increase by about $305 \mathrm{ft}^{3} / \mathrm{s}$. This is less than under the other phase 1 simulation because the large reduction in pumpage would allow water levels to rise further, resulting in less leakage from the rivers. The reduction in pumpage is compensated for principally by increased leakage to drains. Additionally, the reduction in pumpage allows more than 50 percent of the Wanapum unit cells that were desaturated under the other phase 1 simulation to remain saturated. Discharge to the 27 selected basins and 16 selected river reaches (tables 8 and 9) would remain about the same as under the other phase 1 simulation with 1983-85 pumpage.

Under the phase 1 and 2 expansion with reduced pumpage, there are large model-calculated changes in the water budget and flow system from equilibrium conditions and only small changes in the total inflow and outflow quantities from the phase 1 and 2 expansion with 1983-85 pumpage. Thus, the flow system remains about the same as under the phase 1 and 2 expansion with 1983-85 pumpage. However, because the expansion area includes much of the Odessa-Lind pumping center that would be supplied with surfacewater sources, there would be a net reduction in pumpage of about $252 \mathrm{ft}^{3} / \mathrm{s}$ (a 20-percent decrease from equilibrium conditions). This would allow water levels to rise an additional 50 to $100 \mathrm{ft}$ throughout about $160 \mathrm{mi}^{2}$ of both the Wanapum and upper Grande Ronde units.
These rises would result in an increase in discharge to drains of about $1,060 \mathrm{ft}^{3} / \mathrm{s}$ compared to equilibrium conditions, a 24-percent increase compared to the phase 1 and 2 expansion with 1983-85 pumpage.

The calculated discharge to all but one of the selected basins and river reaches generally would be unchanged from equilibrium conditions. Only Bowers Coulee basin (zone number 27 on figure 9, and table 3) would have a large percentage of change in discharge. This basin is located within both the Odessa-Lind pumping center and the expansion area. About 30 percent of the increased leakage to drains under both phase 1 and 2 expansion simulations would be within this basin. Under reduced pumpage, an additional $61 \mathrm{ft}^{3} / \mathrm{s}$ would discharge to drains in this basin, compared with the phase 1 and 2,1983-85 pumpage simulation. Water levels would rise an additional $100 \mathrm{ft}$ throughout much of this basin in both the Wanapum unit and the upper Grande Ronde.

\section{GROUND-WATER QUALITY}

One of the principal factors necessary for economic development of the Columbia Plateau is the availability of large quantities of ground water for irrigation. The suitability of water depends on its quality, and therefore an understanding of the processes that affect groundwater quality is important. Ground-water chemistry can significantly affect the hydrologic characteristics of the rock composing the aquifer system. The filling of fractures with mineral precipitates derived from chemically reactive volcanic glass (which usually has progressed farther in older volcanic rocks than in younger rock) decreases hydraulic conductivity. This is believed to be related to the rate of ground-water flow, the availability of the chemically reactive volcanic glass, and the relatively porous nature of volcanic rocks, which provides a large surface area per unit volume for contact with the water (Wood and Fernandez, 1988).

In the Columbia Plateau RASA study, the regional water-quality characteristics for the basalt units and the geochemical evolution of the ground water were assessed; the results are summarized below. Specific water-quality problems (except for the higher concentrations of sodium in some ground water withdrawn from the basalts) and the water-quality characteristics of the ground water in the overburden aquifer (which are complex due to human activities and the variations in overburden lithology) were not studied. 


\section{WATER-QUALITY CHARACTERISTICS}

Ground water in the basalt units generally is of good quality and suitable for most uses (Steinkampf, 1989). A summary of water chemistry in the three units is included as table 10. The dominant water type in all three units is calcium-magnesium bicarbonate ( $\mathrm{CaMg}$ $\left.\mathrm{HCO}_{3}\right)$. Sodium bicarbonate $\left(\mathrm{Na} \mathrm{HCO}_{3}\right)$ is the next most prevalent type, and calcium-magnesium sulfate-chloride $\left(\mathrm{CaMgSO}_{4} \mathrm{Cl}\right)$ is the least prevalent water type. Sodium bicarbonate water typically occurs in deeper downgradient locations, due to the precipitation of calcium and magnesium and the release of sodium as a result of longer ground-water residence time in the aquifer system.

In the Saddle Mountains unit, in areas of surfacewater irrigation and where the overburden is less than $200 \mathrm{ft}$ thick, water from shallow wells is of a calciummagnesium sulfate-chloride type. Dissolved-solids concentrations generally increase in a downgradient direction because of longer residence time in the aquifer, which effects the evolution of ground-water chemistry. The concentrations of dissolved solids may further increase because of recharge waters from irrigation with high solute concentrations. Nitrogen concentrations (nitrate plus nitrite as $\mathrm{N}$ ) in ground water of $2.0 \mathrm{mg} / \mathrm{L}$

TABLE 10.-Summary of selected water chemistry information for the three basalt units, Columbia Plateau aquifer system (from Steinkampf, 1989) [Values in milligrams per liter unless otherwise indicated]

\begin{tabular}{|c|c|c|c|}
\hline \multicolumn{4}{|c|}{ Saddle Mountains unit, 131 water analyses } \\
\hline & Maximum & Minimum & Mean \\
\hline $\begin{array}{l}\text { Specific conductance (microsiemens } \\
\text { per centimeter at } 25^{\circ} \text { Celsius) }\end{array}$ & 1,460 & 175 & 498.2 \\
\hline Calculated dissolved solids & 890 & 140 & 340.2 \\
\hline Sodium $(\mathrm{Na})$ & 100 & 7.3 & 34.5 \\
\hline Chloride $(\mathrm{Cl})$ & 130 & 1.3 & 24.3 \\
\hline Nitrate + Nitrite $\left(\mathrm{NO}_{3}+\mathrm{NO}_{2}\right.$, as $\left.\mathrm{N}\right)$ & 54 & .1 & 4.8 \\
\hline Silica $\left(\mathrm{SiO}_{2}\right)$ & 72 & 36 & 55.6 \\
\hline Sulfate $\left(\mathrm{SO}_{4}\right)$ & 490 & .2 & 53 \\
\hline Temperature $\left({ }^{\circ}\right.$ Celsius $)$ & 25.5 & 8.6 & 18.36 \\
\hline Dissolved oxygen (DO) & 10.1 & .1 & 4.5 \\
\hline Calcium (Ca) & 98 & 1.9 & 38.28 \\
\hline Magnesium (Mg) & 62 & .28 & 19.4 \\
\hline Fluoride $(\mathrm{F})$ & 2.9 & .2 & .58 \\
\hline Bicarbonate $\left(\mathrm{HCO}_{3}\right)$ & 392 & 108 & 195.4 \\
\hline Iron $(\mathrm{Fe})$ & .79 & .003 & .03 \\
\hline Potassium $(\mathrm{K})$ & 13.0 & 1.5 & 6.9 \\
\hline $\mathrm{pH}$ (standard units) & 8.7 & 7.0 & ${ }^{\mathrm{a}} 7.7$ \\
\hline \multicolumn{4}{|c|}{ Wanapum unit, 410 water analyses } \\
\hline & Maximum & Minimum & Mean \\
\hline Specific conductance (microsiemens & & & \\
\hline $\begin{array}{l}\text { per centimeter at } 25^{\circ} \text { Celsius) } \\
\text { Calculated dissolved solids }\end{array}$ & $\begin{array}{l}1,970 \\
1,100\end{array}$ & $\begin{array}{l}85 \\
69\end{array}$ & $\begin{array}{l}385.6 \\
243\end{array}$ \\
\hline Sodium $(\mathrm{Na})$ & 130 & 2.4 & 40.4 \\
\hline Chloride $(\mathrm{Cl})$ & 300 & .5 & 14.9 \\
\hline Nitrate + Nitrite $\left(\mathrm{NO}_{3}+\mathrm{NO}_{2}\right.$, as $\left.\mathrm{N}\right)$ & 54 & .1 & 2.9 \\
\hline Silica $\left(\mathrm{SiO}_{2}\right)$ & 110 & 10 & 52.3 \\
\hline Sulfate $\left(\mathrm{SO}_{4}\right)$ & 490 & .2 & 30.1 \\
\hline Temperature $\left({ }^{\circ} \mathrm{Celsius}\right)$ & 43.4 & 6.2 & 16.7 \\
\hline Dissolved oxygen (DO) & 10.6 & .1 & 4.5 \\
\hline Calcium $(\mathrm{Ca})$ & 180 & .8 & 30.8 \\
\hline Magnesium (Mg) & 75 & .01 & 14.1 \\
\hline Fluoride $(\mathrm{F})$ & 4.9 & .1 & .53 \\
\hline Bicarbonate $\left(\mathrm{HCO}_{3}\right)$ & 455 & 43 & 166.2 \\
\hline Iron $(\mathrm{Fe})$ & 10 & .003 & .05 \\
\hline Potassium (K) & 22.0 & .9 & 5.1 \\
\hline $\mathrm{pH}$ (standard units) & 9.4 & 6.1 & ${ }^{\mathrm{a}} 7.5$ \\
\hline
\end{tabular}


TABLE 10.-Summary of selected water chemistry information for the three basalt units, Columbia Plateau aquifer system (from Steinkampf, 1989)—Continued [Values in milligrams per liter unless otherwise indicated]

\begin{tabular}{|c|c|c|c|}
\hline \multicolumn{4}{|c|}{ Grande Ronde unit, 283 water analyses } \\
\hline & Maximum & Minimum & Mean \\
\hline \multirow{2}{*}{\multicolumn{4}{|c|}{$\begin{array}{l}\text { Specific conductance (microsiemens } \\
\text { per centimeter at } 25^{\circ} \text { Celsius) }\end{array}$}} \\
\hline & 830 & 85 & 311.8 \\
\hline Calculated dissolved solids & 510 & 94 & 234.1 \\
\hline Sodium $(\mathrm{Na})$ & 90 & 4 & 24.9 \\
\hline Chloride $(\mathrm{Cl})$ & 45 & .5 & 7.1 \\
\hline Nitrate + Nitrite $\left(\mathrm{NO}_{3}+\mathrm{NO}_{2}\right.$, as $\left.\mathrm{N}\right)$ & 15 & .1 & .96 \\
\hline Silica $\left(\mathrm{SiO}_{2}\right)$ & 110 & 29 & 56.5 \\
\hline Sulfate $\left(\mathrm{SO}_{4}\right)$ & 100 & .2 & 21.8 \\
\hline Temperature $\left({ }^{\circ} \mathrm{Celsius}\right)$ & 36.7 & 7.6 & 18 \\
\hline Dissolved oxygen (DO) & 10.2 & .1 & 3.3 \\
\hline Calcium $(\mathrm{Ca})$ & 88 & .95 & 24.5 \\
\hline Magnesium (Mg) & 38 & .13 & 10.7 \\
\hline Fluoride $(\mathrm{F})$ & 4.9 & .1 & .6 \\
\hline Bicarbonate $\left(\mathrm{HCO}_{3}\right)$ & 455 & 43 & 170.3 \\
\hline Iron $(\mathrm{Fe})$ & 10 & .003 & .098 \\
\hline Potassium (K) & 13 & 1.1 & 4.7 \\
\hline $\mathrm{pH}$ (standard units) & 9.4 & 6.7 & ${ }^{\mathrm{a}} 7.6$ \\
\hline \multicolumn{4}{|c|}{ All basalt units, 824 water analyses } \\
\hline & Maximum & Minimum & Mean \\
\hline \multirow{2}{*}{\multicolumn{4}{|c|}{$\begin{array}{l}\text { Specific conductance (microsiemens } \\
\text { per centimeter at } 25^{\circ} \text { Celsius) }\end{array}$}} \\
\hline & 1,970 & 85 & 402.5 \\
\hline Calculated dissolved solids & 1,100 & 69 & 269.5 \\
\hline Sodium $(\mathrm{Na})$ & 130 & 2.4 & 28 \\
\hline Chloride $(\mathrm{Cl})$ & 300 & .5 & 17.2 \\
\hline Nitrate + Nitrite $\left(\mathrm{NO}_{3}+\mathrm{NO}_{2}\right.$, as $\left.\mathrm{N}\right)$ & 54 & .1 & 3.7 \\
\hline Silica $\left(\mathrm{SiO}_{2}\right)$ & 110 & 10 & 48.3 \\
\hline Sulfate $\left(\mathrm{SO}_{4}\right)$ & 490 & .2 & 29.3 \\
\hline Temperature $\left({ }^{\circ} \mathrm{Celsius}\right)$ & 43.4 & 6.2 & 15.5 \\
\hline Dissolved oxygen (DO) & 10.6 & .1 & 5.2 \\
\hline Calcium $(\mathrm{Ca})$ & 180 & .8 & 32.8 \\
\hline Magnesium (Mg) & 75.0 & .01 & 14.8 \\
\hline Fluoride $(\mathrm{F})$ & 4.9 & .1 & .5 \\
\hline Bicarbonate $\left(\mathrm{HCO}_{3}\right)$ & 455 & 43 & 178.1 \\
\hline Iron $(\mathrm{Fe})$ & 10 & .003 & .03 \\
\hline Potassium (K) & 22.0 & .9 & 4.9 \\
\hline pH (standard units) & 9.4 & 6.1 & ${ }^{\mathrm{a}} 7.4$ \\
\hline
\end{tabular}

${ }^{\text {a }}$ Mean value represents the negative base- $10 \log$ of the average hydrogen ion concentration in moles per liter.

or larger occur in areas where the overburden aquifer is thin and where surface water is used for irrigation. The recharging surface water transports large quantities of nitrogen derived from agricultural chemicals. The mean dissolved-solids concentration for the Saddle Mountains unit is about $340 \mathrm{mg} / \mathrm{L}$ (table 10).

The concentration of dissolved solids in the Wanapum unit averaged about $240 \mathrm{mg} / \mathrm{L}$. For this unit, calcium-magnesium sulfate-chloride waters are generally found in wells shallower than $400 \mathrm{ft}$, in areas where the overburden is less than $200 \mathrm{ft}$ thick, and in areas where dissolved-oxygen concentrations in ground water are greater than $4.0 \mathrm{mg} / \mathrm{L}$. Sodium concentrations greater than $25 \mathrm{mg} / \mathrm{L}$ are found in downgradient and discharge areas. Nitrogen concentrations are generally less than $2.0 \mathrm{mg} / \mathrm{L}$ in waters from wells deeper than about $500 \mathrm{ft}$. Larger nitrogen concentrations, greater than $10 \mathrm{mg} / \mathrm{L}$, are found in water from wells less than $300 \mathrm{ft}$ deep and where the overburden is thin or absent-generally in the central part of the plateau. The origin of this dissolved nitrogen is unknown, but agricultural chemicals are the most likely source. The vertical variation in nitrogen concentrations in the Wanapum unit is probably due either to variations in the direction of flow or to the possibility that nitrogen- 
enriched water has not reached the deeper depths at this time; the former is most likely.

The mean concentration of dissolved solids of water in the Grande Ronde unit is $234 \mathrm{mg} / \mathrm{L}$ and reflects concentrations of solutes generally smaller than in the other units. Sodium concentrations increase with ground-water residence time, and the largest concentrations are found in samples from the deepest wells. In general, sodium concentrations are larger in the central part of the plateau. Dissolved nitrogen is not a significant constituent in the Grande Ronde unit, and no measured concentrations were larger than $2.0 \mathrm{mg} / \mathrm{L}$. This is probably because in the areas with intensive irrigation, the Grande Ronde unit is generally overlain by thick layers of the other basalts and, thus, the water chemistry in the Grande Ronde unit is not affected by irrigation.

\section{GEOCHEMICAL MODEL}

The chemical composition of water in the aquifer system depends on the composition and relative solubility of the rocks through which the water flows, the chemical composition of the recharge water, and the residence time of the water in the aquifer system. Solute concentrations also are influenced by the hydrologic processes occurring in the system. These aspects were investigated by Steinkampf and Hearn (1996) and are briefly summarized below.

Rocks of the Columbia River Basalt Group consist primarily of labradorite (plagioclase feldspar), augite (pyroxene), and opaque metal oxides (commonly titanomagnetite) in a matrix of volcanic glass and cryptocrystalline material. The most common accessory minerals are apatite, olivine, and metallic sulfides. These are present in varying and minor amounts as intergrown and isolated crystals. The most abundant secondary minerals are a nontronitic smectite, quartz, clinoptilolite, and iron oxyhydroxides (Ames, 1980; Benson and Teague, 1982; Hearn and others, 1985). The Grande Ronde, Wanapum, and Saddle Mountains Basalts are compositionally distinct, and individual flows within these units also can have distinct mineral compositions. On the basis of bulk compositions, Swanson and Wright (1978) described eight chemical types of basalt in the northern part of the plateau.

The primary means by which solutes are added to ground water in the basalt are dissolution of rock by weakly acidic recharge waters and dissolution by silicate hydrolysis. The presence of a soil zone in the recharge area increases the dissolution capacity of the recharging water by carbon-dioxide generation. Carbon dioxide is formed by the microbial oxidation of organic carbon and dissolves to carbonic acid. In areas devoid of a soil zone or vegetative cover, and in the semiconfined to confined aquifers where little or no oxygen penetrates from the atmosphere, carbonic acid usually is not generated. In such areas, silicate hydrolysis is the dominant dissolution process. Volcanic glass, a major component of the Columbia River Basalt, is the most reactive mineral. In decreasing order, cryptocrystalline intergrowths, olivine, pyroxene, and feldspar are the next most reactive.

The most abundant solutes added to ground water by dissolution of the basalt are calcium, magnesium, iron, sodium, potassium, silica, sulfate, chloride, fluoride, and bicarbonate. Dissolution of minerals by carbonic acid increases the concentrations of all of those constituents and also increases ground-water $\mathrm{pH}$. Silicate hydrolysis also increases the concentrations of solutes, and, because the hydroxyl ion is produced in the reaction, increases $\mathrm{pH}$ even more than does acidic dissolution. Increasing ground-water $\mathrm{pH}$ eventually exceeds the stability limits of calcium carbonate, which can then precipitate calcite from solution, lowering calcium and magnesium levels and contributing to decreased iron concentrations, effectively buffering the ground-water $\mathrm{pH}$. Sodium and potassium are dissolved faster than they are removed. As dissolved sodium, potassium, and silica concentrations increase, the ground water eventually becomes supersaturated with clinoptilolite. Clinoptilolite, which incorporates dissolved sodium and potassium, then precipitates, consequently limiting the concentrations of sodium and potassium in the basalts.

Dissolved-silica concentrations are large in ground water from basalt because of the readily dissolved glassy material present. Silica levels are limited by the solubility of amorphous or opaline silica. The relatively large silica concentrations buffer the $\mathrm{pH}$ of the water, limiting the increase from the hydrolysis reaction to a $\mathrm{pH}$ of about 9.5.

Sulfate in ground water in the basalt has three likely sources. The first is the dissolution of accessory metallic sulfide minerals, such as pyrite, in the presence of dissolved oxygen. The second is the dissolution of anhydrite or gypsum from sedimentary interbeds interlayered with the basalt. Sulfate minerals in the interbeds are likely to be of either eolian or evaporative (caliche) origin. The third source is agricultural chemicals present in ground-water recharge. Sulfide has been found in some ground-water samples from the plateau, and is probably derived from the microbial reduction of dissolved sulfate.

Trace elements in the ground water also are derived from the weathering of minerals composing the rock matrix. The concentration of a trace element in solution 
depends upon a variety of factors, many of which are difficult to quantify in natural systems. Concentrations of some elements are controlled by the chemical characteristics of the ground water, whereas concentrations of others are a function of their availability in the basaltic rock. For example, the concentrations of barium, calcium, fluorine, and iron are likely controlled by the chemical characteristics of the water and the solubilities of relevant secondary minerals such as barite, calcite, fluorite, and iron oxyhydroxides. In contrast, elements such as lithium, strontium, and boron (that increase in concentration with increasing total concentration of dissolved solids) are usually controlled by availability of the element in the rock.

\section{SELECTED REFERENCES}

Ames, L.L., 1980, Hanford basalt flow mineralogy: Richland, Washington, Report INL-2847, Pacific Northwest Laboratory, 447 p.

Bauer, H.H., and Hansen, A.J., in press, Hydrology of the Columbia Plateau regional aquifer system, Washington, Oregon, and Idaho: U.S. Geological Survey Water-Resources Investigations Report 96-4106, 63 p.

Bauer, H.H., and Vaccaro, J.J., 1986, Model estimates of climatological variability on ground water: Conference on Climate and Water Management: A Critical Era, American Meteorological Society, Ashville, N.C., August 4-7, 1986, p. 45-49.

1987a, Estimation of the spatial and temporal distributions of evapotranspiration and deep percolation; Part I. The Model [abs.]: EOS, Transactions of the American Geophysical Union, v. 68, no. 44, November 3, 1987, p. 1,299.

$1987 \mathrm{~b}$, Documentation of a deep percolation model for estimating ground-water recharge: U.S. Geological Survey Open-File Report 86-536, $180 \mathrm{p}$.

1990, Estimates of ground-water recharge to the Columbia Plateau regional aquifer system, Washington, Oregon, and Idaho, for predevelopment and current land-use conditions: U.S. Geological Survey Water-Resources Investigations Report 88-4108, 37 p., 2 plates.

Bauer, H.H., Vaccaro, J.J., and Lane, R.C., 1985, Maps showing ground-water levels in the Columbia River Basalt and overlying material, spring 1983, southeastern Washington: U.S. Geological Survey Water-Resources Investigations Report 84-4360, 4 sheets.

Benson, L.V., and Teague, L.S., 1982, Diagenesis of basalts from the Pasco Basin, Washington-I. Distribution and composition of secondary mineral phases: Journal of Sedimentary Petrology, v. 52 , no. 2, p. 595-613.

Cline, D.R., 1984, Ground-water levels and pumpage in east-central Washington, including the Odessa-Lind area, 1967 to 1981: Washington State Department of Ecology, Water-Supply Bulletin no. 55,34 p.

Cline, D.R., and Collins, C.A., 1992, Ground-water pumpage in the Columbia Plateau, Washington and Oregon, 1945 to 1984: U.S. Geological Survey Water-Resources Investigations Report 904085,31 p., 5 plates.

Cline, D.R., and Knadle, M.E., 1990, Ground-water pumpage from the Columbia Plateau regional aquifer system, Washington, 1984: U.S. Geological Survey Water-Resources Investigations Report $87-4135,32$ p., 1 sheet.
Collins, C.A., 1987, Ground-water pumpage from the Columbia Plateau regional aquifer system, Oregon, 1984: U.S. Geological Survey Water-Resources Investigations Report 86-4211, $21 \mathrm{p}$.

Davies-Smith, A., Bolke, E.L., and Collins, C.A., 1988, Geohydrology and digital simulation of the ground-water flow system in the Umatilla Plateau and Horse Heaven Hills area, Oregon and Washington: U.S. Geological Survey Water-Resources Investigations Report 87-4268, 70 p.

Drost, B.W., and Whiteman, K.J., 1986, Surficial geology, structure, and thickness of selected geohydrologic units in the Columbia Plateau, Washington: U.S. Geological Survey Water-Resources Investigations Report 84-4326, 10 sheets.

Drost, B.W., Whiteman, K.J., and Gonthier, J.B., 1990, The geologic framework of the Columbia Plateau regional aquifer system, Washington, Oregon, and Idaho: U.S. Geological Survey WaterResources Investigations Report 87-4238, 10 p., 10 sheets.

Farooqui, S.M., Beaulieu, J.B., Bunker, R.C., Stensland, D.E., and Thoms, R.E., 1981, Dalles Group: Neogene formations overlying the Columbia River Basalt Group in north-central Oregon: Oregon Department of Geology and Mineral Industries, Oregon Geology, v. 43, no. 10, p. 131-140.

Ferris, J.G., Knowles, D.B., Brown, R.H., and Stallman, R.W., 1962, Theory of aquifer test: U.S. Geological Survey Water-Supply Paper 1536-E, $174 \mathrm{p}$.

Flint, R.F., 1938, Summary of late-Cenozoic geology of southeastern Washington: American Journal of Science, v. 35, p. 223-230.

Freeman, O.W., Forrester, J.O., and Lupher, R.L., 1945, Physiographic divisions of the Columbia Intermontane Province: Association American Geographer Annals, v. 35, no. 2, p. 50-75.

Gonthier, J.B., 1990, Geology, structure, and thickness of hydrogeologic units in part of the Columbia Plateau, Oregon: U.S. Geological Survey Water-Resources Investigations Report 86-4001, 6 sheets.

Hansen, A.J., 1993a, Archiving of source code for the finite-difference flow model and the post-processors and input and output files for the Columbia Plateau regional aquifer system, Washington, Oregon, and Idaho: U.S. Geological Survey Open-File Report 90$364,9 \mathrm{p}$.

Hansen, A.J., 1993b, Modifications to the modular three-dimensional, finite difference, ground-water flow model used for the Columbia Plateau Regional Aquifer-System Analysis, Washington, Oregon, and Idaho: U.S. Geological Survey Open-File Report 91$532,162 \mathrm{p}$.

Hansen, A.J., Vaccaro, J.J., and Bauer, H.H., 1994, Ground-water flow simulation of the Columbia Plateau regional aquifer system, Washington, Oregon, and Idaho: U.S. Geological Survey WaterResources Investigations Report 91-4178, 81 p., 15 sheets.

Hearn, P.P., Steinkampf, W.C., Bortleson, G.C., and Drost, B.W., 1985, Geochemical controls on dissolved sodium in basalt aquifers of the Columbia Plateau, Washington: U.S. Geological Survey Water-Resources Investigations Report 84-4304, 38 p.

Hooper, P.R., 1982, The Columbia River Basalts: Science, v. 215, no. 4539 , p. 1,463-1,468.

Lane, R.C., 1988a, Selected ground-water information for the Columbia Plateau regional aquifer system, Washington and Oregon, 1982-1985: Volume 1. Geohydrology: U.S. Geological Survey Open-File Report 88-182, 236 p.

1988b, Selected ground-water information for the Columbia Plateau regional aquifer system, Washington and Oregon, 19821985: Volume 2. Water-levels: U.S. Geological Survey Open-File Report 88-183, 136 p.

Lane, R.C., and Whiteman, K.J., 1989, Ground-water levels, spring 1985, and ground-water level changes, spring 1983 to spring 1985, in three basalt units underlying the Columbia Plateau, 
Washington and Oregon: U.S. Geological Survey WaterResources Investigations Report 88-4018, 4 sheets.

Lindholm, G.F., and Vaccaro, J.J., 1988, Region 2 Columbia Lava Plateau, chapter 5, in Back, W., Rosenshein, J.S., and Seaber, P.R., eds., Hydrogeology, The Geology of North America: Volume 0-2: Decade of North American Geology Project, Geological Society of America, Boulder, Colorado, p. 37-50.

Lum, W.E., Smoot, J.L., and Ralston, D.R., 1990, Geohydrology and numerical model analysis of ground-water flow in the PullmanMoscow Area, Washington and Idaho: U.S. Geological Survey Water-Resources Investigations Report 89-4103, 73 p.

MacNish, R.D., and Barker, R.A., 1976, Digital simulation of a basalt aquifer system, Walla Walla River basin, Washington and Oregon: Washington Department of Ecology Water-Supply Bulletin $44,51 \mathrm{p}$.

McDonald, M.G., and Harbaugh, A.W., 1988, A modular three-dimensional finite-difference ground-water flow model: U.S. Geological Survey Techniques of Water Resources Investigations, Book 6, Chap. 41, 11 chaps.

Myers, C.W., and Price, S.M., 1979, Geologic studies of the Columbia Plateau, a status report: Richland, Wash., Rockwell International, Rockwell Hanford Operations Report RHO-BWI-ST-4, $520 \mathrm{p}$.

Nelson, L.M., 1991, Surface-water resources for the Columbia Plateau, Washington, Oregon, and Idaho: U.S. Geological Survey WaterResources Investigations Report 88-4105, 4 sheets.

Neuzil, C.E., 1986, Ground-water flow in low-permeability environments: Water Resources Research, v. 22, no. 8, p. 1,163-1,195.

Newcomb, R.C., 1965, Geology and ground-water resources of the Walla Walla River basin, Washington-Oregon: Washington Division of Water Resources, Water-Supply Bulletin 21, 151 p. 1969, Effect of tectonic structure on the occurrence of ground water in the basalt of the Columbia River Group of The Dalles area, Oregon and Washington: U.S. Geological Survey Professional Paper 383-C, 33 p.

Prych, E.A., 1983, Numerical simulation of ground-water flow in lower Satus Creek basin, Yakima Indian Reservation, Washington: U.S. Geological Survey Water-Resources Investigations Report 82-4065, $78 \mathrm{p}$.

Reidel, S.P., 1982, Stratigraphy of the Grande Ronde Basalt, Columbia River Basalt Group, from the lower Salmon River and northern Hells Canyon area, Idaho, Oregon, and Washington, in Bonnichsen, Bill, and Breckenridge, R.M., eds., Cenozoic geology of Idaho: Idaho Bureau of Mines and Geology Bulletin 26, p. 77101.

Stearns, R.T., 1942, Hydrology of lava-rock terranes, chap. XV, in Meinzer, O.E., ed., Hydrology: New York, McGraw-Hill, 712 p.

Steinkampf, W.C., 1989, Water-quality characteristics of the Columbia Plateau regional aquifer system in parts of Washington, Oregon, and Idaho: U.S. Geological Survey Water-Resources Investigations Report 87-4242, $37 \mathrm{p}$.

Steinkampf, W.C., Bortleson, G.C., and Packard, F.A., 1985, Controls on ground-water chemistry in the Horse Heaven Hills, southcentral Washington: U.S. Geological Survey Water-Resources Investigations Report 85-4048, 26 p.

Steinkampf, W.C., and Hearn, P.P., 1996, Ground-water geochemistry of the Columbia Plateau regional aquifer system, Washington, Oregon, and Idaho: U.S. Geological Survey Open-File Report 95$467,67 \mathrm{p}$.

Sun, R.J., 1986, Introduction, in Sun, R.J., ed., Regional Aquifer-System Analysis Program of the U.S. Geological Survey: Summary of Projects, 1978-1984: U.S. Geological Survey Circular 1002, p. $1-8$
Swanson, D.A., 1967, Yakima Basalt of the Tieton River area, southcentral Washington: Geological Society of America Bulletin, v. 78, p. 1,077-1,110.

Swanson, D.A., Anderson, J.L., Bentley, R.D., Byerly, G.R., Camp, V.E. Gardner, J.N., and Wright, T.L., 1979a, Reconnaissance geologic map of the Columbia River Basalt Group in eastern Washington and northern Idaho: U.S. Geological Survey Open-File Report 79-1363, 26 p., scale 1:250,000, 12 sheets.

Swanson, D.A., Anderson, J.L., Camp, V.E., Hooper, P.R., Taubeneck, W.H., and Wright, T.L., 1981, Reconnaissance geologic map of the Columbia River Basalt Group, northern Oregon and western Idaho: U.S. Geological Survey Open-File Report 81-797, 35 p.

Swanson, D.A., Brown, J.C., Anderson, J.L., Bentley, R.D., Byerly, G.R., Gardner, J.N., and Wright, T.L., 1979b, Preliminary structure contour maps on the top of the Grande Ronde and Wanapum Basalts, eastern Washington and northern Idaho: U.S. Geological Survey Open-File Report 79-1364, scale 1:500,000, 2 sheets.

Swanson, D.A., and Wright, T.L., 1978, Bedrock geology of the southern Columbia Plateau and adjacent areas, chap. 3, in Baker, V.R. and Nummedal, D., eds., The channeled scabland: Washington, D.C., Planetary Geology Program, National Aeronautical and Space Administration, p. 37-57.

Swanson, D.A., Wright, T.L., and Helz, R.T., 1975, Linear vent systems and estimated rates of magma production and eruption for the Yakima Basalt on the Columbia Plateau: American Journal of Science, v. 275, October 1975, p. 877-905.

Swanson, D.A., Wright, T.L., Hooper, P.R., and Bentley, R.D., 1979c, Revisions in stratigraphic nomenclature of the Columbia River Basalt Group: U.S. Geological Survey Bulletin 1457-G, 59 p.

Swanson, D.A., Wright, T.L., and Zeitz, I., 1979d, Aeromagnetic map and geologic interpretation of the west-central Columbia Plateau, Washington and adjacent Oregon: U.S. Geological Survey Geophysical Investigations Map GP-917, scale 1:250,000.

Theis, C.V., 1963, Estimating the transmissibility of a water-table aquifer from the specific capacity of a well, in Bentall, Ray, compiler, Methods of determining permeability, transmissibility, and drawdown: U.S. Geological Survey Water-Supply Paper 1536-I, p. 332-336.

Tolan, T.L., Reidd, S.P., Beeson, M.H., Anderson, J.L., Fecht, K.R., and Swanson, D.A., 1987, Revisions to the areal extent and volume of the Columbia River Basalt Group [abs.]: Geological Society of America, Abstracts with Programs, v. 19, no. 6, p. 458.

Vaccaro, J.J., 1986a, Plan of study for the Regional Aquifer-System Analysis, Columbia Plateau, Washington, northern Oregon, and northwestern Idaho: U.S. Geological Survey Water-Resources Investigations Report 85-4151, 25 p.

1986b, Columbia Plateau basalt Regional Aquifer-System study, in Sun, R.J., ed., Regional Aquifer-System Analysis Program of the U.S. Geological Survey: Summary of Projects, 1978-84: U.S. Geological Survey Circular 1002, p. 141-146.

1991, Sensitivity of ground-water recharge estimates to climate variability and change, Ellensburg basin, Columbia Plateau, Washington: U.S. Geological Survey Water-Resources Investigations Report 91-4001, $30 \mathrm{p}$.

Vaccaro, J.J., and Bauer, H.H., 1987, Estimation of the spatial and temporal distributions of evapotranspiration and deep percolation; Part II. Application to the Columbia Plateau, Washington, Oregon, and Idaho [abs.]: EOS, Transactions of the American Geophysical Union, v. 68 , no. 44 , p. 1,299.

1990, Archiving of deep percolation models, data files, and calculated recharge estimates for the Columbia Plateau regional aquifer system, Washington, Oregon, and Idaho: U.S. Geological Survey Open-File Report 88-186, 15 p.

Wagner, R.A., and Lane, R.C., 1994, Selected ground-water information for the Columbia Plateau regional aquifer system, Washing- 
ton and Oregon, 1982-1985: Volume 3. Water-quality: U.S. Geological Survey Open-File Report 93-359, 226 p.

Water Conservation Steering Committee, 1987, Columbia basin project EIS water conservation steering committee report, executive summary, submitted to the U.S. Bureau of Reclamation, Boise, Idaho, September, 1987, 23 p.

Whiteman, K.J., 1986, Ground-water levels in three basalt hydrologic units underlying the Columbia Plateau in Washington and Oregon, spring 1984: U.S. Geological Survey Water-Resources Investigations Report 86-4046, 4 sheets.
Whiteman, K.J., Vaccaro, J.J., Gonthier, J.B., and Bauer, H.H., 1994, The hydrogeologic framework and geochemistry of the Columbia Plateau aquifer system, Washington, Oregon, and Idaho: U.S. Geological Survey Professional Paper 1413-B, 74 p.

Wood, W. and Fernandez, L.A., 1988, Volcanic rocks, chap. 39, in Back, W., Rosenshein, J.S., and Seaber, P.R., eds., Hydrogeology, The Geology of North America, Volume 0-2: Boulder, Colorado, Geological Society of America, Decade of North American Geology Project, p. 353-365. 





\section{Selected Series of U.S. Geological Survey Publications}

\section{Books and Other Publications}

Professional Papers report scientific data and interpretations of lasting scientific interest that cover all facets of USGS investigations and research.

Bulletins contain significant data and interpretations that are of lasting scientific interest but are generally more limited in scope or geographic coverage than Professional Papers.

Water-Supply Papers are comprehensive reports that present significant interpretive results of hydrologic investigations of wide interest to professional geologists, hydrologists, and engineers. The series covers investigations in all phases of hydrology, including hydrogeology, availability of water, quality of water, and use of water.

Circulars are reports of programmatic or scientific information of an ephemeral nature; many present important scientific information of wide popular interest. Circulars are distributed at no cost to the public.

Fact Sheets communicate a wide variety of timely information on USGS programs, projects, and research. They commonly address issues of public interest. Fact Sheets generally are two or four pages long and are distributed at no cost to the public.

Reports in the Digital Data Series (DDS) distribute large amounts of data through digital media, including compact discread-only memory (CD-ROM). They are high-quality, interpretive publications designed as self-contained packages for viewing and interpreting data and typically contain data sets, software to view the data, and explanatory text.

Water-Resources Investigations Reports are papers of an interpretive nature made available to the public outside the formal USGS publications series. Copies are produced on request (unlike formal USGS publications) and are also available for public inspection at depositories indicated in USGS catalogs.

Open-File Reports can consist of basic data, preliminary reports, and a wide range of scientific documents on USGS investigations. Open-File Reports are designed for fast release and are available for public consultation at depositories.

\section{Maps}

Geologic Quadrangle Maps (GQ's) are multicolor geologic maps on topographic bases in 7.5- or 15-minute quadrangle formats (scales mainly 1:24,000 or 1:62,500) showing bedrock, surficial, or engineering geology. Maps generally include brief texts; some maps include structure and columnar sections only.

Geophysical Investigations Maps (GP's) are on topographic or planimetric bases at various scales. They show results of geophysical investigations using gravity, magnetic, seismic, or radioactivity surveys, which provide data on subsurface structures that are of economic or geologic significance.
Miscellaneous Investigations Series Maps or Geologic Investigations Series (I's) are on planimetric or topographic bases at various scales; they present a wide variety of format and subject matter. The series also incudes 7.5-minute quadrangle photogeologic maps on planimetric bases and planetary maps.

\section{Information Periodicals}

Metal Industry Indicators (MII's) is a free monthly newsletter that analyzes and forecasts the economic health of five metal industries with composite leading and coincident indexes: primary metals, steel, copper, primary and secondary aluminum, and aluminum mill products.

Mineral Industry Surveys (MIS's) are free periodic statistical and economic reports designed to provide timely statistical data on production, distribution, stocks, and consumption of significant mineral commodities. The surveys are issued monthly, quarterly, annually, or at other regular intervals, depending on the need for current data. The MIS's are published by commodity as well as by State. A series of international MIS's is also available.

Published on an annual basis, Mineral Commodity Summaries is the earliest Government publication to furnish estimates covering nonfuel mineral industry data. Data sheets contain information on the domestic industry structure, Government programs, tariffs, and 5-year salient statistics for more than 90 individual minerals and materials.

The Minerals Yearbook discusses the performance of the worldwide minerals and materials industry during a calendar year, and it provides background information to assist in interpreting that performance. The Minerals Yearbook consists of three volumes. Volume I, Metals and Minerals, contains chapters about virtually all metallic and industrial mineral commodities important to the U.S. economy. Volume II, Area Reports: Domestic, contains a chapter on the minerals industry of each of the 50 States and Puerto Rico and the Administered Islands. Volume III, Area Reports: International, is published as four separate reports. These reports collectively contain the latest available mineral data on more than 190 foreign countries and discuss the importance of minerals to the economies of these nations and the United States.

\section{Permanent Catalogs}

"Publications of the U.S. Geological Survey, 1879-1961" and "Publications of the U.S. Geological Survey, 19621970" are available in paperback book form and as a set of microfiche.

'Publications of the U.S. Geological Survey, 1971-1981" is available in paperback book form (two volumes, publications listing and index) and as a set of microfiche.

Annual supplements for 1982, 1983, 1984, 1985, 1986, and subsequent years are available in paperback book form. 


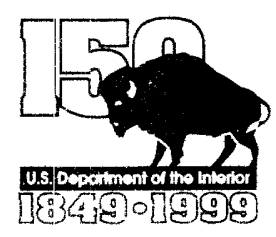

